THERMOPHYSICAL PROPERTIES OF

THORIUM AND URANIUM SYSTEMS

FOR USE IN REACTOR SAFETY ANALYSIS

by

Joanne K. Fink, Martin G. Chasanov, and Leonard Leibowitz

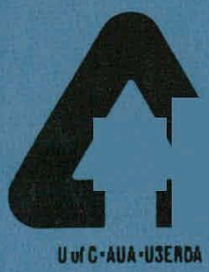

ARGONNE NATIONAL LABORATORY, ARGONNE, ILLINOIS

Prepared for the U.S. ENERGY RESEARCH

AND DEVELOPMENT ADMINISTRATION

under Contract W-31-109-Eng-38 


\section{DISCLAIMER}

This report was prepared as an account of work sponsored by an agency of the United States Government. Neither the United States Government nor any agency Thereof, nor any of their employees, makes any warranty, express or implied, or assumes any legal liability or responsibility for the accuracy, completeness, or usefulness of any information, apparatus, product, or process disclosed, or represents that its use would not infringe privately owned rights. Reference herein to any specific commercial product, process, or service by trade name, trademark, manufacturer, or otherwise does not necessarily constitute or imply its endorsement, recommendation, or favoring by the United States Government or any agency thereof. The views and opinions of authors expressed herein do not necessarily state or reflect those of the United States Government or any agency thereof. 


\section{DISCLAIMER}

Portions of this document may be illegible in electronic image products. Images are produced from the best available original document. 
The facilities of Argonne National Laboratory are owned by the United States Government. Under the terms of a contract (W-31-109-Eng-38) between the U. S. Energy Research and Development Administration, Argonne Universities Association and The University of Chicago, the University employs the staff and operates the Laboratory in accordance with policies and programs formulated, approved and reviewed by the Association.

\section{MEMBERS OF ARGONNE UNIVERSITIES ASSOCIATION}

The University of Arizona. Carnegie-Mellon University Case Western Reserve University

The University of Chicago

University of Cincinnati

Illinois Institute of Technology

University of Illinois

Indiana University

Iowa State University

The University of Iowa
Kansas State University The University of Kansas Loyola University Marquette University Michigan State University The University of Michigan University of Minnesota University of Missouri Northwestern University University of Notre Dame
The Ohio State University

Ohio University

The Pennsylvania State University

Purdue University

Saint Louis University

Southern Illinois University

The University of Texas at Austin

Washington University

Wayne State University

The University of Wisconsin

NOTICE

This report was prepared as an account of work sponsored by the United States Government. Neither the United States nor the United States Energy Research and Development Administration, nor any of their employees, nor any of their contractors, subcontractors, or their employees, makes any warranty, express or implied, or assumes any legal liability or responsibility for the accuracy, completeness or usefulness of any information, apparatus, product or process disclosed, or represents that its use would not infringe privately-owned rights. Mention of commercial products, their manufacturers, or their suppliers in this publication does not imply or connote approval or disapproval of the product by Argonne National Laboratory or the U. S. Energy Research and Development Administration. 


\author{
ARGONNE NATIONAL LABORATORY \\ 9700 South Cass Avenue \\ Argonne, Illinois 60439
}

\title{
THERMOPHYSICAL PROPERTIES OF THORIUM AND URANIUM \\ SYSTEMS FOR USE IN REACTOR SAFETY ANALYSIS
}

\section{by}

Joanne K. Fink, Martin G. Chasanov, and Leonard Leibowitz

Chemical Engineering Division

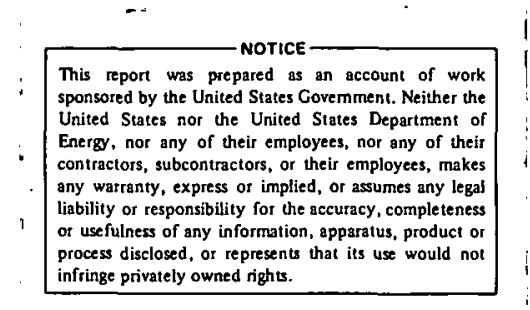

June 1977 


\section{THIS PAGE}

WAS INTENTIONALLY

LEFT BLANK 
INTRODUCTION . . . . . . . . . . . . . . . . . . . . 1

THORIUM . . . . . . . . . . . . . . . . . . . . . . 8

Melting Point... . . . . . . . . . . . . . . . . 8

Boiling Point... . . . . . . . . . . . . . . . 8

Entha1py, ${ }_{(\mathrm{MP})}-\mathrm{H}_{(298)}$. . . . . . . . . . . . . . 8

Heat of Fusion, $\Delta_{\mathrm{m}}$. . . . . . . . . . . . . . . . . . . . . 8

Enthalpy, ${ }_{(\mathrm{BP})}-\mathrm{H}_{(298)}$. . . . . . . . . . . . . . . 8

Heat of Vaporization, $\Delta \mathrm{H}_{\mathrm{V}}$. . . . . . . . . . . . . . 8

Heat Capacity, $\mathrm{C}_{\mathrm{p}(298)}$. . . . . . . . . . . . . . . . 9

Heat Capacity, $\mathrm{C}_{\mathrm{p}}^{(\mathrm{s})}$. . . . . . . . . . . . . . . . . 9

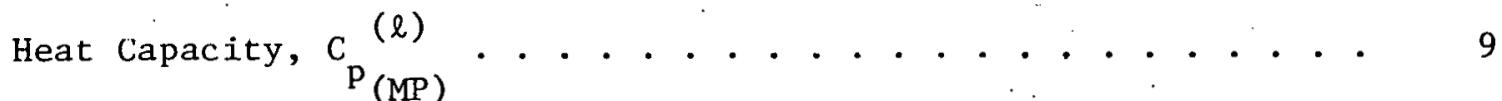

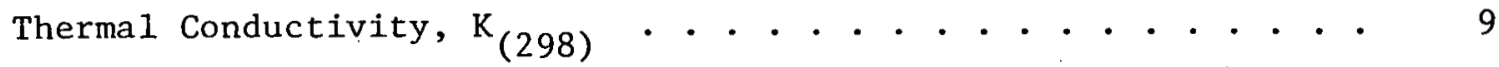

Density, $\rho_{(2)}^{(s)}$. . . . . . . . . . . . . . . . . . . 9

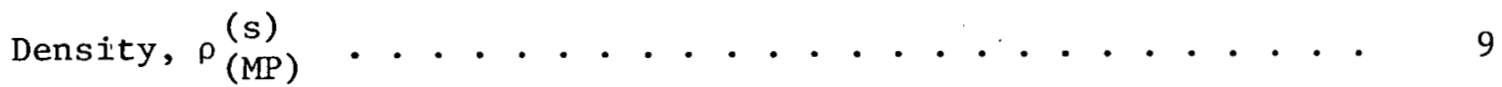

Volumetric Thermal Expansion Coefficient, $\bar{\alpha}_{(298-M P)}^{(s)} \cdot \ldots . . . .10$

Phase Transition, $\alpha \rightarrow \beta$. . . . . . . . . . . . . . 10

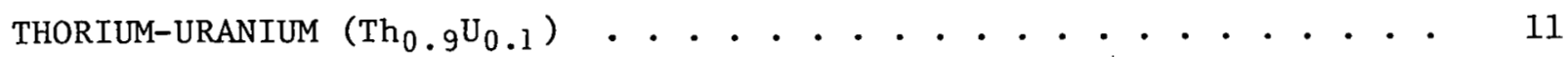

Melting Point . . . . . . . . . . . . . . . . . . . 11

Boiling Point . . . . . . . . . . . . . . . . . . . 11

Enthalpy, ${ }_{(M P)}{ }^{-}{ }_{(298)}$. . . . . . . . . . . . . . . 11

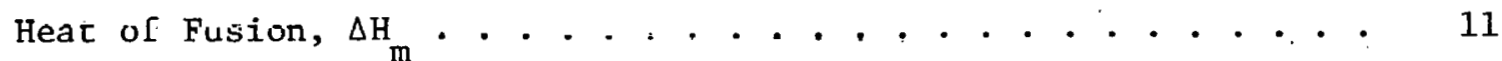

Enthalpy, $\mathrm{H}_{(\mathrm{BP})}{ }^{-\mathrm{H}_{(298)}}$. . . . . . . . . . . . . 11

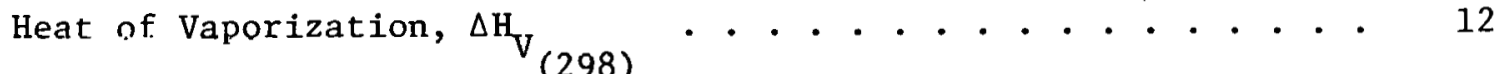

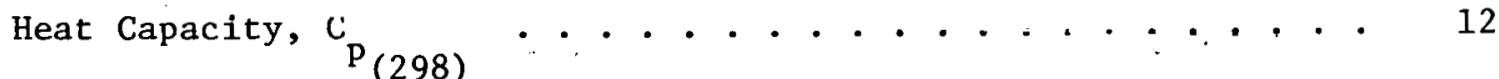


Heat Capacity, $\mathrm{c}^{(\mathrm{s})}$. . . . . . . . . . . . . . . . 12

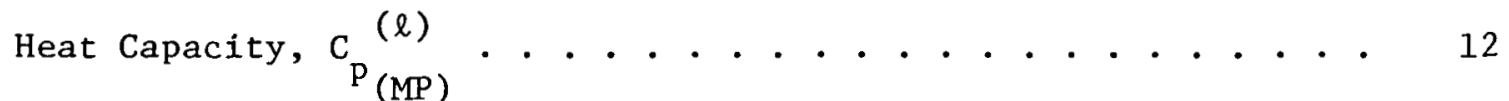

Thermal Conductivity, $\mathrm{K}_{(298)}$. . . . . . . . . . . . 12

Density, ${ }_{(\mathrm{s})}^{(\mathrm{s})} \cdot$. . . . . . . . . . . . . . . . . 12

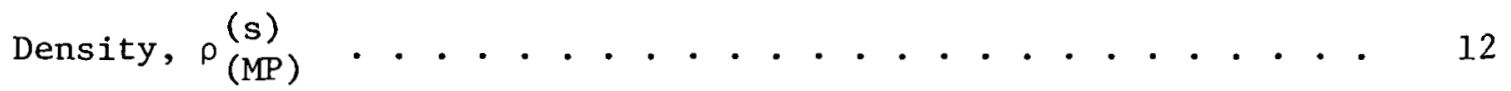

URANIUM (U) . . . . . . . . . . . . . . . . . . . . . . . . . . . . 13

Melting Point . . . . . . . . . . . . . . . . . . . 1J

Bolling loint . . . . . . . . . . . . . . . . . . . . . 13

Enthalpy, ${ }_{(M P)}-\mathrm{H}_{(298)}$. . . . . . . . . . . . . . 13

Heat of Fusion, $\Delta_{\mathrm{m}}$. . . . . . . . . . . . . . . . . . . . . . . 14

Enthalpy, $\mathrm{H}_{(\mathrm{BP})}-\mathrm{H}_{(298)} \cdot \cdot \cdot \cdot \cdot \cdot \cdot \cdot \cdot \cdot \cdot \cdot \cdot \cdot \cdot \cdot \cdot \cdot 14$

Heat of Vaporization, $\Delta \mathrm{H}_{\mathrm{V}}$. . . . . . . . . . . . . . 14

Heat Capacity, $\mathrm{C}_{(298)} \cdot \cdot \cdot \cdot \cdot \cdot \cdot \cdot \cdot \cdot \cdot \cdot \cdot \cdot \cdot \cdot \cdot \cdot \cdot 14$

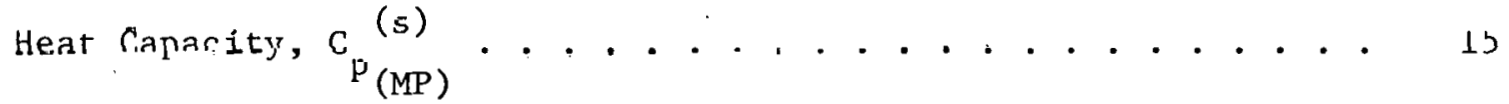

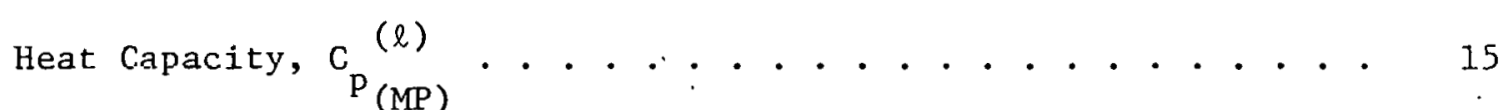

Thermal Condurtivity, $K_{(298)}$. . . . . . . . . . . . . 15

Density, $\rho_{(298)}^{(s)}$. . . . . . . . . . . . . . . . . . 15

Volumetric Thermal Expansion Coefficient, $\bar{\alpha}_{(298-M P)}^{(s)} . . . . . . \quad 15$

Temperature of Phase Transitions . . . . . . . . . . . 15 THORIA $\left(\mathrm{ThO}_{2}\right)$

Melting Point . . . . . . . . . . . . . . . . . 16

Boiling Point . . . . . . . . . . . . . . . . . . . 16

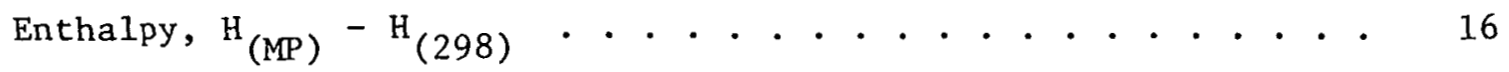

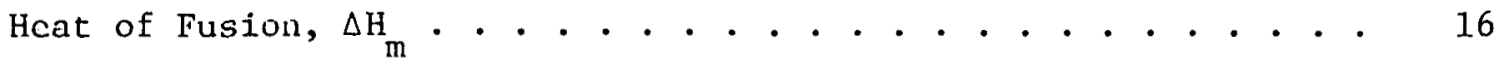


Enthalpy, $\mathrm{H}_{(\mathrm{BP})}-\mathrm{H}_{(298)}$. . . . . . . . . . . . . 16

Heat of Vaporization, $\Delta \mathrm{H}_{(298)} \cdot \ldots \cdot \ldots \cdot \ldots$

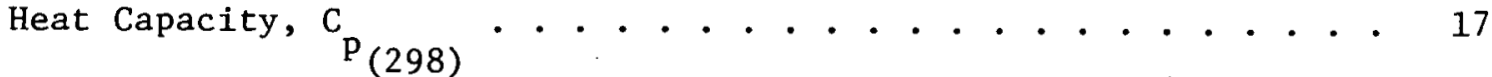

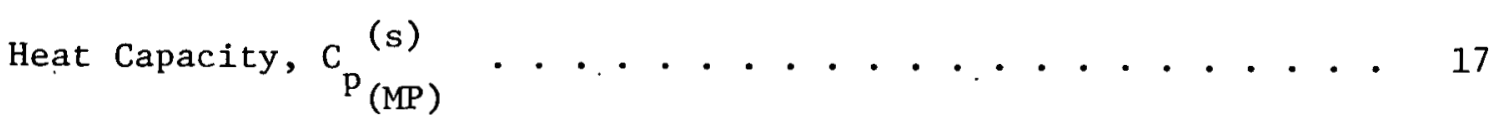

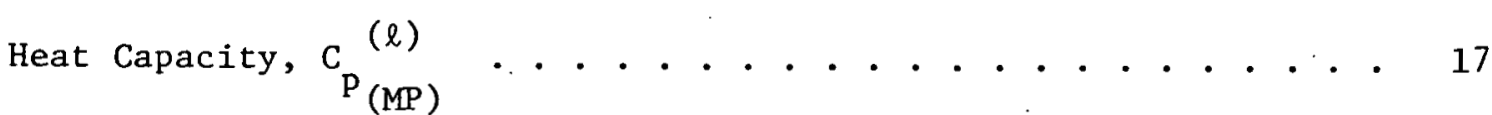

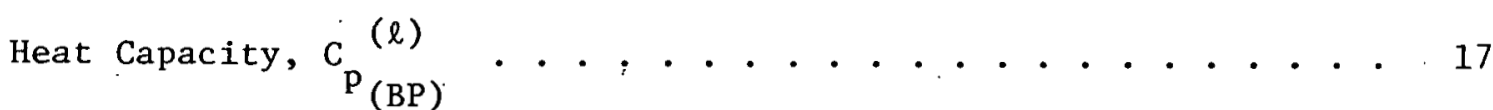

Thermal Conductivity, $\mathrm{K}_{(298)}$. . . . . . . . . . . . . . . . 18

Density, $\rho(s)(298)$. . . . . . . . . . . . . . . . . . . . 18

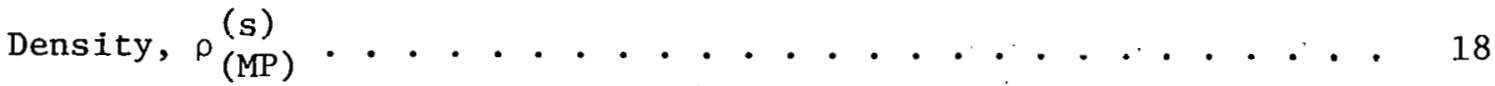

Change in Density on Melting, $-\frac{\Delta \rho}{\rho}$ MP . . . . . . . . . . . . . 18

Volumetric Thermal Expansion Coefficient, $\bar{\alpha}^{(s)}$. . . . . . . . . 18

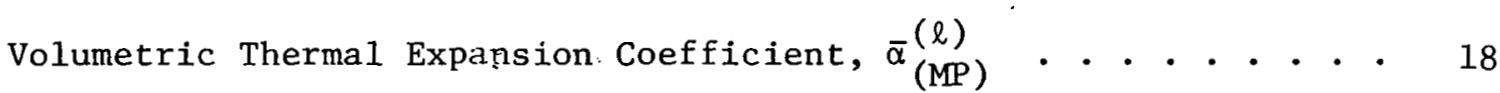

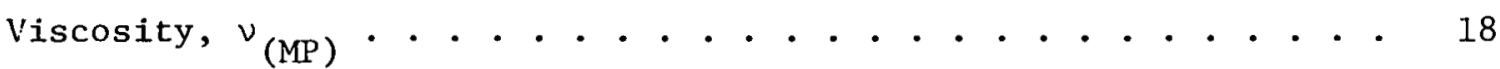

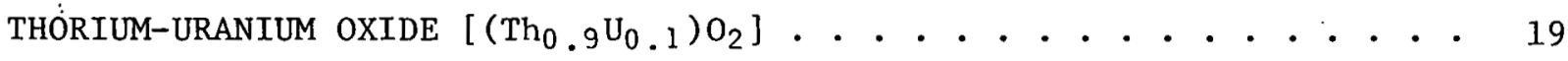

Melting Point . . . . . . . . . . . . . . . . . . . 19

Boiling Point . . . . . . . . . . . . . . . . 19

Enthalpy, ${ }_{(M P)}-\mathrm{H}_{(298)}$. . . . . . . . . . . . 19

Heat of Fusion, $\Delta_{\mathrm{m}}$. . . . . . . . . . . . . . . . . . . 19

Enthalpy, ${ }_{(\mathrm{BP})}{ }^{-\mathrm{H}_{(298)}}$. . . . . . . . . . . . . 19

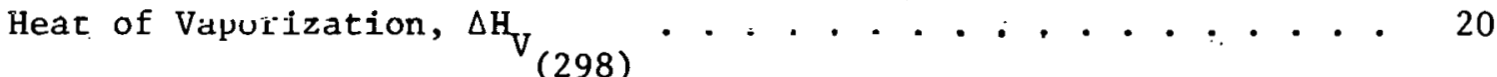

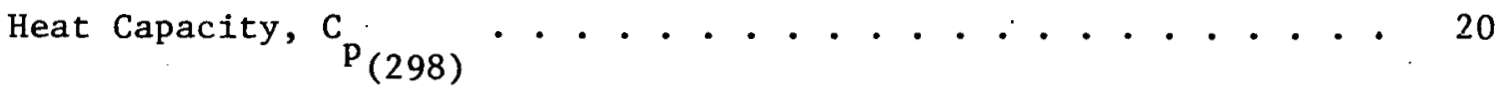

Heat Capacity, $\mathrm{c}_{\mathrm{p}}(\mathrm{s})$

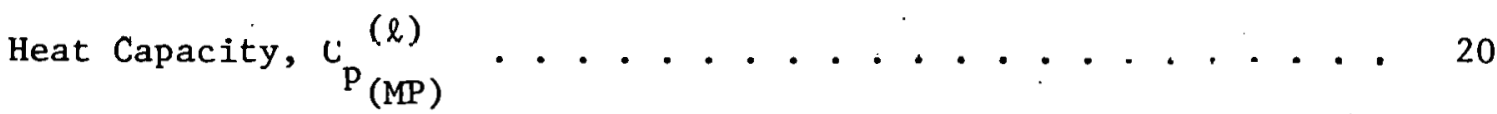


Heat Capacity, $\mathrm{C}_{\mathrm{P}}^{\mathrm{(BP})}(\mathrm{l})$

Thermal Conductivity, $\mathrm{K}_{(298)}$. . . . . . . . . . . . . 20

Dens1ty, ${ }_{(298)}^{(s)}$. . . . . . . . . . . . . . . . . . 21

Density, $\rho(s)$

Change in Density on Melting, $\left(-\frac{\Delta \rho}{\rho}\right)_{\mathbb{P P}} \cdot \ldots \cdot \ldots \cdot \ldots+\ldots$

Volumetric Thermal Expansion Coefficient, $\bar{\alpha}_{(298-M P)}^{(s)} \cdot \ldots . . . . \quad 21$

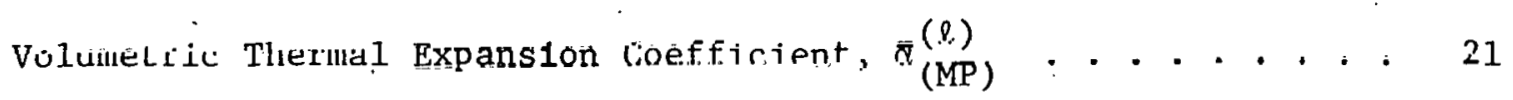

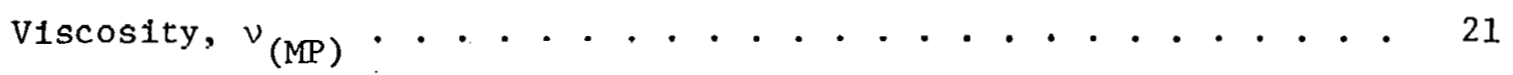

URANIA $\left(\mathrm{UO}_{2}\right)$. . . . . . . . . . . . . . . . . . . . . . 22

Melting Point . . . . . . . . . . . . . . . . . 22

Boiling Point . . . . . . . . . . . . . . . . . . 22

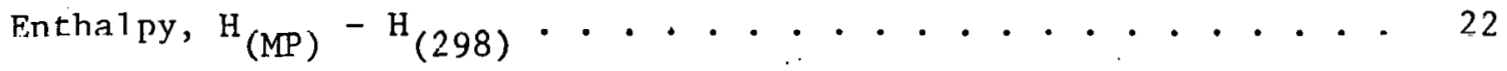

Heat of f'usion, $\Delta_{\mathrm{m}}$. . . . . . . . . . . . . . . . . . . . 22

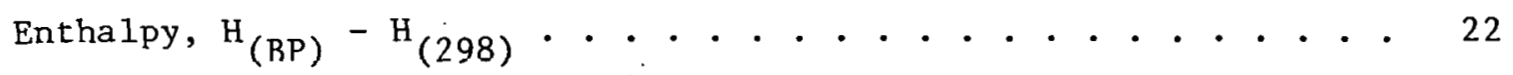

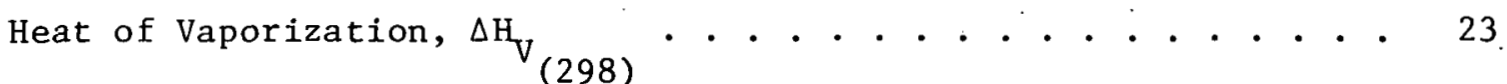

Heat of Vaporization, $\Delta \mathrm{H}_{\mathrm{V}}$. . . . . . . . . . . . . . 23

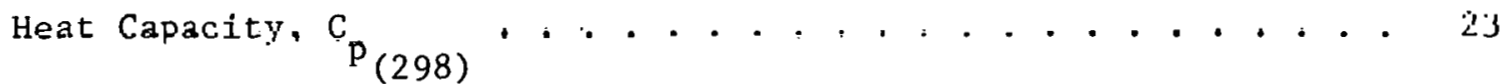

Heat Capacity, $\mathrm{C}_{\mathrm{p}}^{(\mathrm{s})}$. . . . . . . . . . . . . . . . . 23

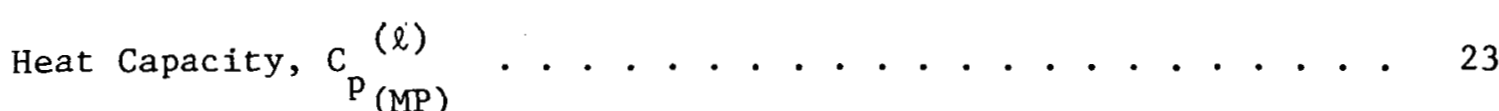

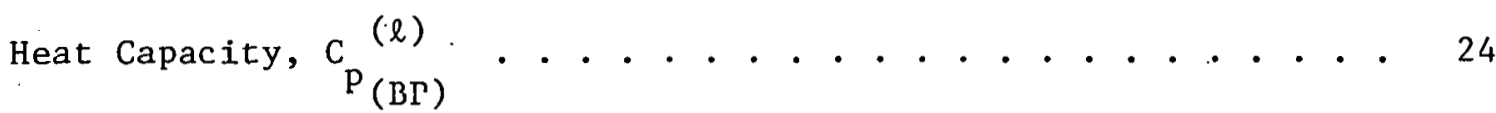

Thermal Conductivity, $\mathrm{K}_{(298)}$. . . . . . . . . . . . . . . 24

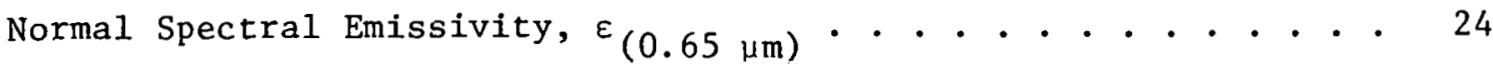




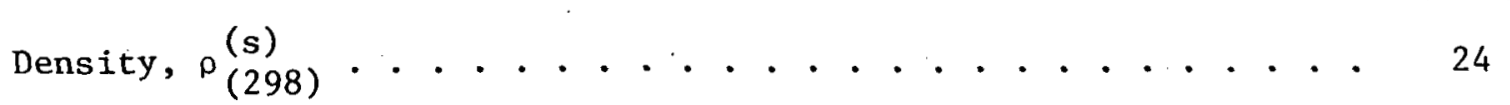

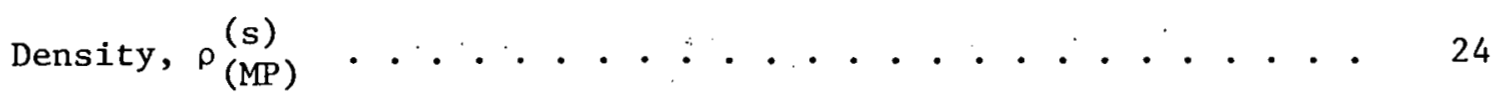

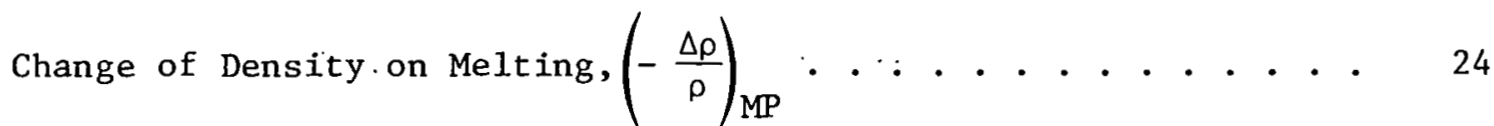

Volumetric Thermal Expansion Coefficient, $\bar{\alpha}_{(298-M P)}^{(s)} \cdot$. . . . . 24

Volumetric Thermal Expansion Coefficient, $\bar{\alpha}_{(\mathrm{MP})}^{(\ell)}$. . . . . . . 25

Viscosity, ${ }_{(\mathrm{MP})}$. . . . . . . . . . . . . . . . . 25

Surface Tension, $\sigma$. . . . . . . . . . . . . . . 25

URANIUM-PLUTONIUM OXIDE $\left[\left(\mathrm{U}_{0.8} \mathrm{Pu}_{0.2}\right)_{2}\right] \ldots \ldots$

Melting Point..................... . . 26

Boiling Point...................... . . . 26

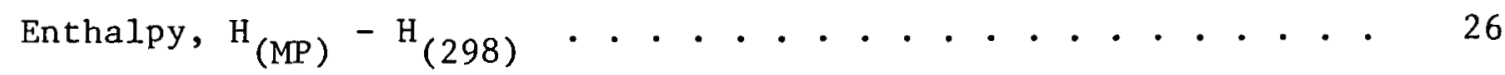

Heat of Fusion, $\Delta_{\mathrm{m}}$. . . . . . . . . . . . . . . . . 26

Enthalpy, ${ }_{(\mathrm{BP})}{ }^{-\mathrm{H}_{(298)}}$. . . . . . . . . . . . . 26

Heat of Vaporization, $\Delta \mathrm{H}_{\mathrm{V}}$. . . . . . . . . . . . . 26

Heat of Vaporization, $\Delta \mathrm{H}_{(B P)}$. . . . . . . . . . . . . 27

Heat Capacity, $\mathrm{C}_{\mathrm{P}_{(298)}}$. ................... 27

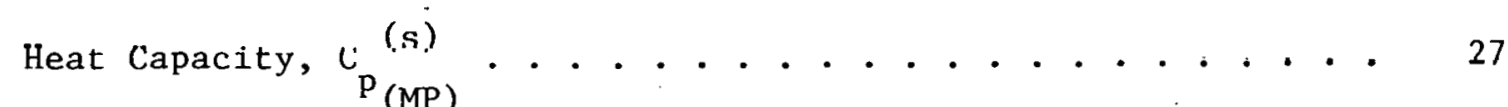

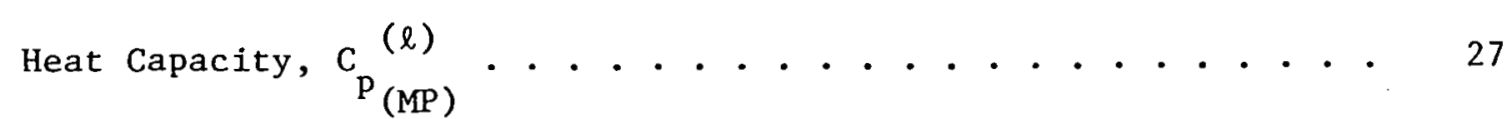

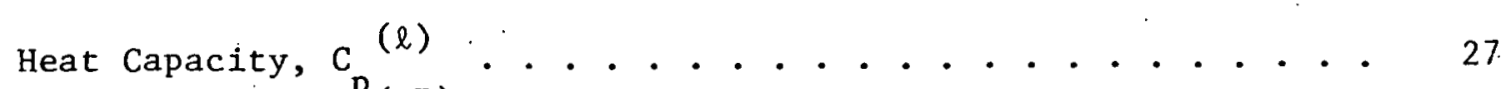

Thermal Condurtivity, $\mathrm{K}_{(298)}$. . . . . . . . . . . . . 27

Normal Spectral Emissivity, $\varepsilon_{(0.65 \mu \mathrm{m})}$. . . . . . . . . . 27

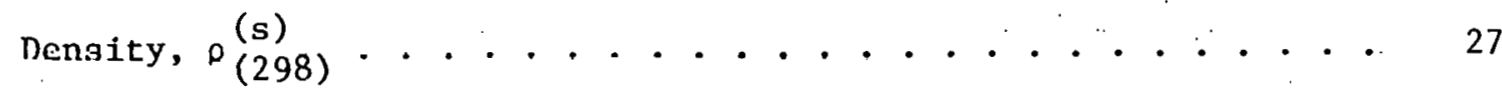




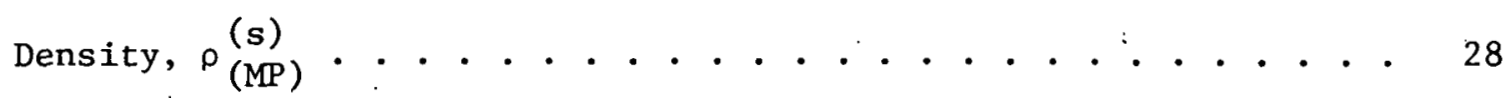

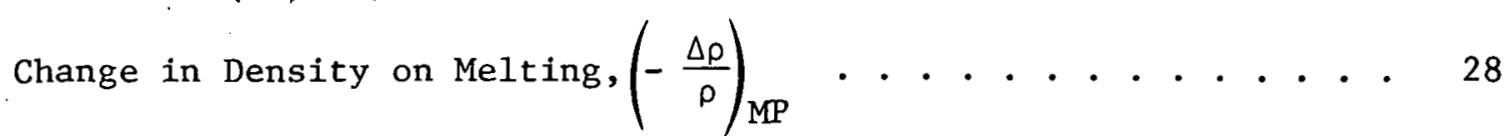

Volumetric Thermal Expansion Coefficient, $\bar{\alpha}_{(298-M P)}^{(s)}$. . . . . 28

Volumetric Thermal Expansion Coefficient, $\bar{\alpha}_{(\mathrm{MP})}^{(\ell)}$. . . . . . . 29

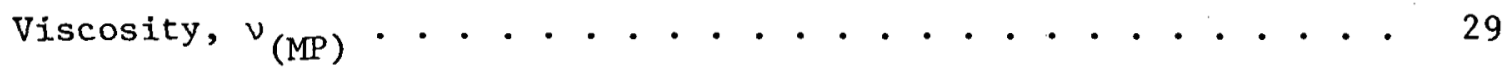

Surface Tension, o. . . . . . . . . . . . . . . . . 29

THORIUM CARBIDE (ThC)

Melting Point . . . . . . . . . . . . . . . . 30

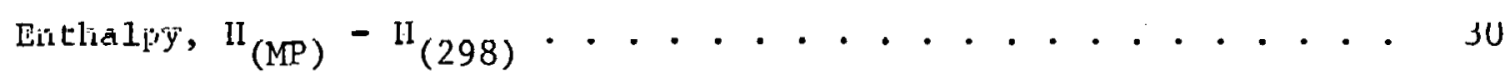

Heat of Fusion, $\Delta \mathrm{ll}_{\mathrm{m}}$. . . . . . . . . . . . . . . . . . 30

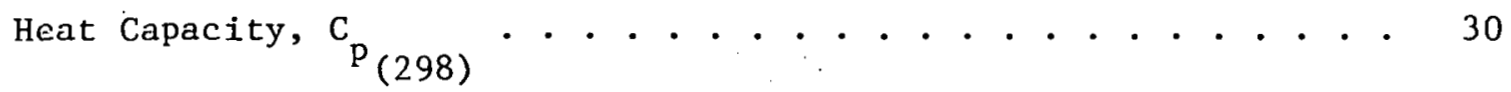

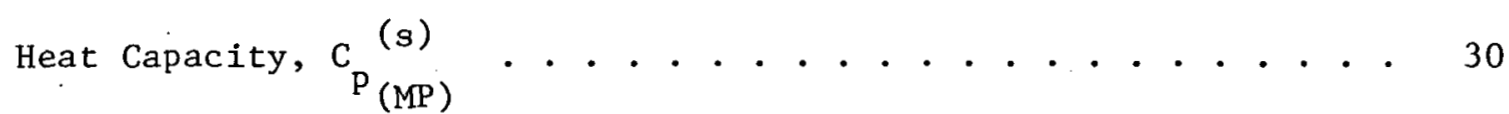

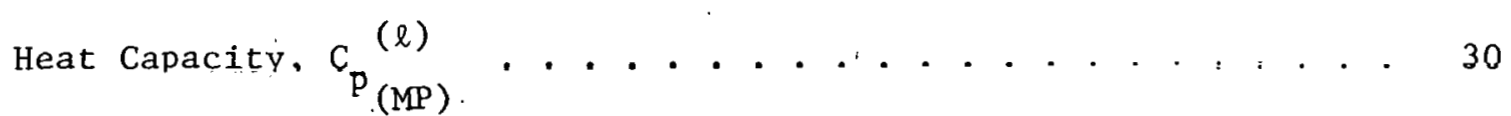

Thermal Conductivity, $\mathrm{K}_{(298)}$. . . . . . . . . . . . . . . . 30

Density, $\rho(s)(298)$. . . . . . . . . . . . . . . . . . 30

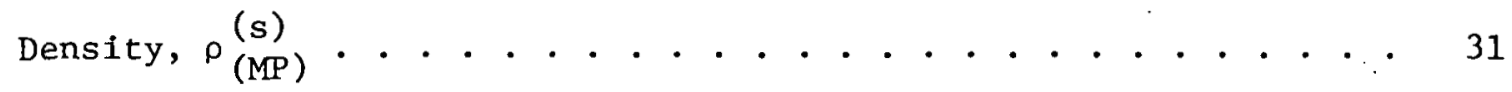

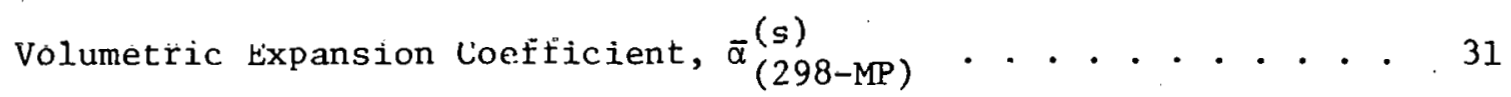

THORIUM-URANIUM CARBIDE $\left[\left(\mathrm{Th}_{0}, \mathrm{~g}_{0.1}\right) \mathrm{C}\right]$

Melting Point . . . . . . . . . . . . . . . . . . 32

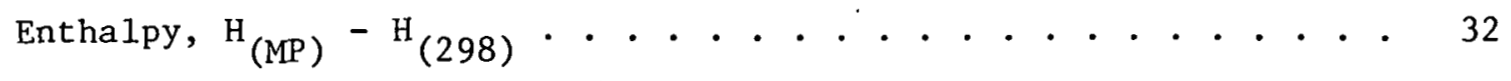

Heat of Fusion, $\Delta \mathrm{H}_{\mathrm{m}}$. . . . . . . . . . . . . . . . . . 32

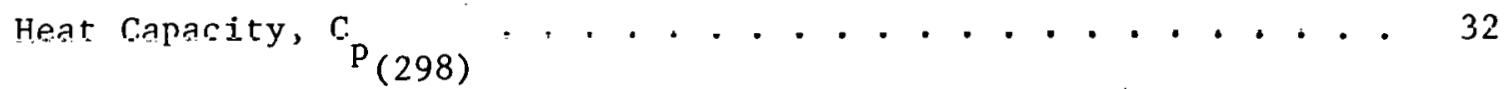

Heat Capacity, $\mathrm{C}_{\mathrm{P}}^{(\mathrm{MP})}{ }^{(\mathrm{s})}$. . . . . . . . . . . . . . . . 32 
Heat Capacity, $\mathrm{C}_{\mathrm{p}}^{(\mathrm{MP})}$

Thermal Conductivity, $\mathrm{K}_{(298)}$

Density, $\rho \stackrel{(s)}{(298)}$

Density, $\rho \stackrel{(s)}{(\mathrm{MP})}$

Volumetric Thermal Expansion Coefficient, $\frac{-(s)}{(298-M P)}$

URANIUM CARBIDE (UC)

Melting Point . . . . . . . . . . . . . . . . . 33

Boiling Point........................ . 33

Critical Temperature . . . . . . . . . . . . . . . . 33

Enthalpy, ${ }_{(M P)}{ }^{-H_{(298)}}$. . . . . . . . . . . . . 33

Heat of Fusion, $\Delta_{\mathrm{m}}$. . . . . . . . . . . . . . . . . . . 33

Enthalpy, $\mathrm{H}_{(\mathrm{BP})}{ }^{-\mathrm{H}_{(298)}}$. . . . . . . . . . . . . 33

Heat of Vaporization, $\Delta \mathrm{H}_{\mathrm{v}}$. . . . . . . . . . . . . . 33

Heat Capacity, $\mathrm{C}_{\mathrm{P}_{(298)}}$. . . . . . . . . . . . . . 33

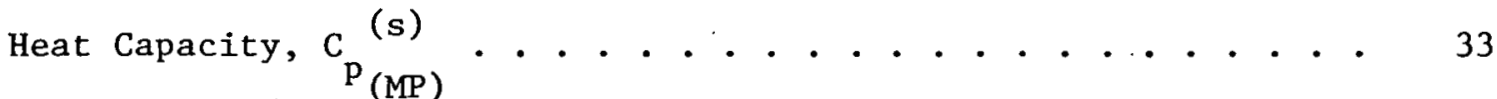

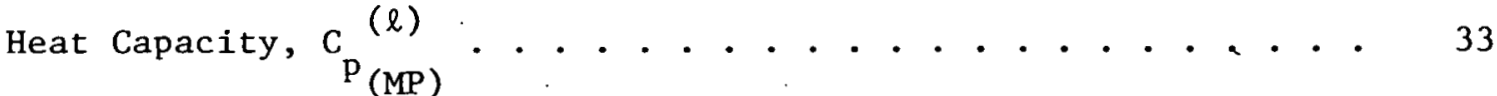

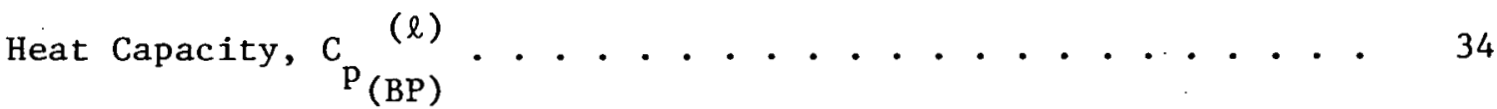

Thermal Conductivity, $\mathrm{K}_{(298)}$. . . . . . . . . . . . . 34

Thermal Conductivity, $\mathrm{K}_{(\mathrm{MP})}^{(\mathrm{s})}$. . . . . . . . . . . . . 34

Thermal Conductivity, $\mathrm{K}_{(\mathrm{MP})}^{(\ell)}$. . . . . . . . . . . . 34

Norma1 Total Emissivity, $\varepsilon_{\mathrm{T}}$. . . . . . . . . . . . . . 34

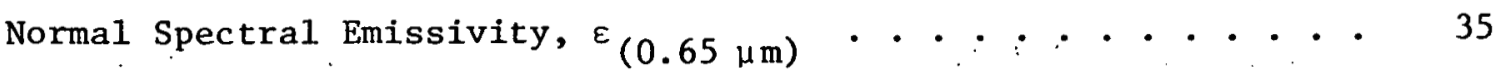

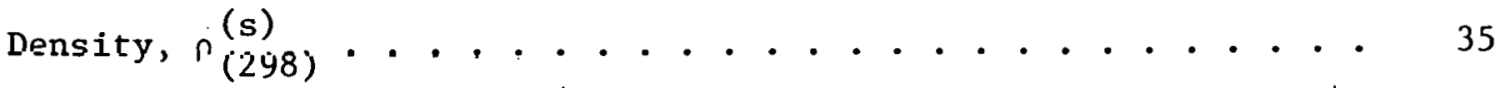

Density, ${ }^{(s)}(\mathrm{MP})$. . . . . . . . . . . . . . . . 35 


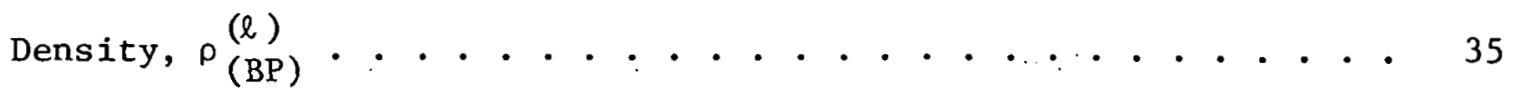

Volumetric Thermal Expansion Coefficient, $\bar{\alpha}_{(298-M P)}^{(s)} \cdot \ldots . . . \cdot 35$

Volumetric Therma1 Expansion Coefficient, $\bar{\alpha}_{(\mathrm{MP})}^{(\ell)}$. . . . . . . . 35

Isothermal Compressibility, $\kappa_{\mathrm{T}(298)}$. . . . . . . . . . . . 35

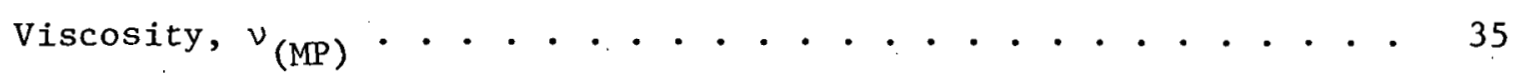

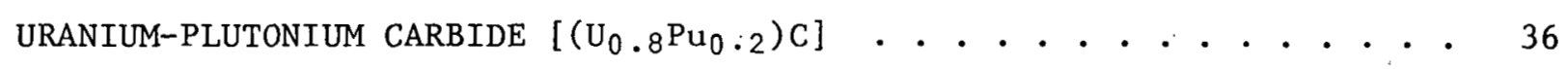

Melting Point . . . . . . . . . . . . . . . . . 36

Boiling Point . . . . . . . . . . . . . . . . . 36

lintical lemperature . . . . . . . . . . . . . . . . 36

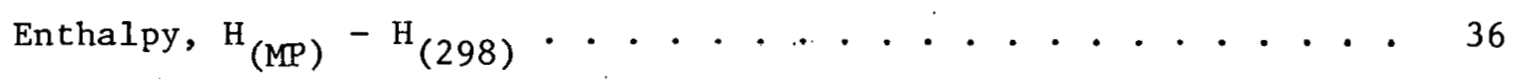

Heat of Fusion, $\Delta \dot{\mathrm{H}}_{\mathrm{m}}$. . . . . . . . . . . . . . . . . . . 36

Enthalpy, $\mathrm{H}_{(\mathrm{BP})}{ }^{-\mathrm{H}_{(298)}}$. . . . . . . . . . . . . 36

Heat of Vaporization, $\Delta \mathrm{H}_{(298)}$. . . . . . . . . . . . . . 36

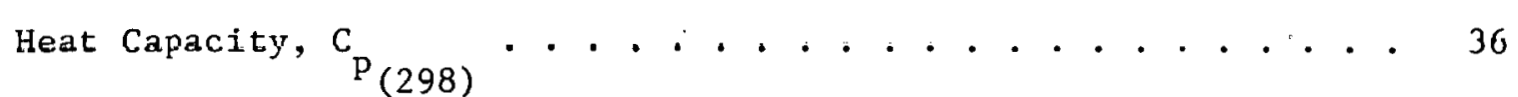

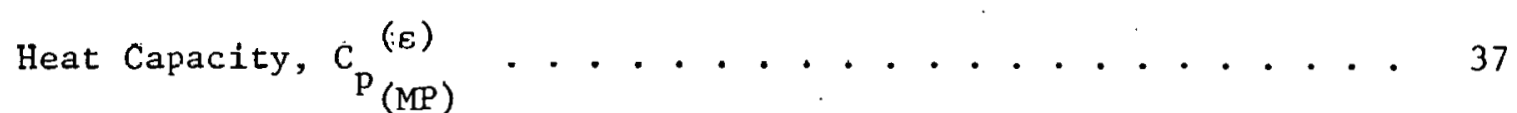

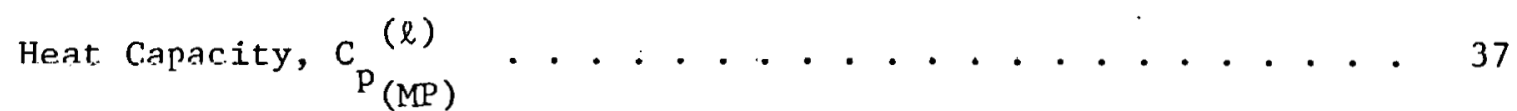

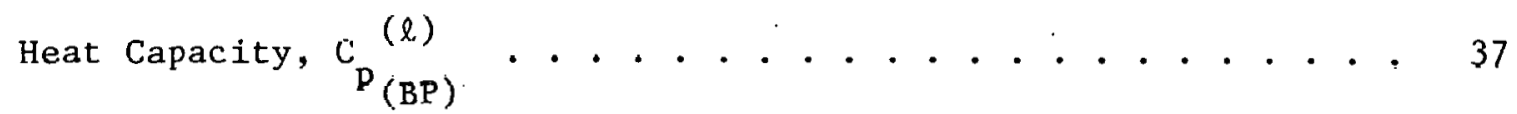

Thcrma 1 Conductivity, $K_{(298)}$. . . . . . . . . . . . . 37

Thermal Conductivity, $\mathrm{K}_{(\mathrm{MP})}^{(\mathrm{s})}$. . . . . . . . . . . . . . 37

Thermal Conductivity, $\mathrm{K}_{(\mathrm{MP})}^{(\ell)}$. . . . . . . . . . . . . . . 37

Density, ${ }_{(298)}^{(s)}$. . . . . . . . . . . . . . . . . . 37

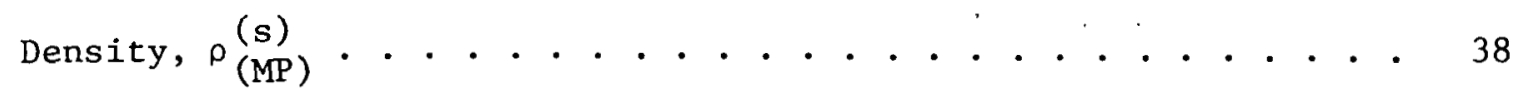

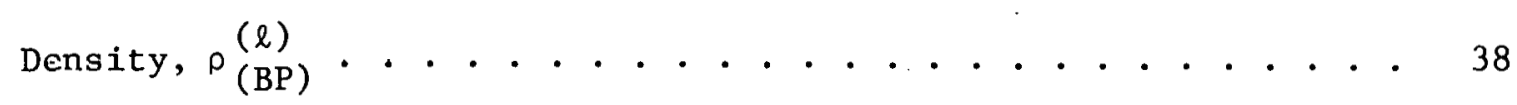


Volumetric Thermal Expansion Coefficient, $\bar{\alpha}_{(298-M P)}^{(s)} \cdot \ldots . . . \quad 38$

Volumetric Thermal Expansion Coefficient, $\bar{\alpha}_{(\mathrm{MP})}^{(\ell)} \ldots . . \ldots 38$

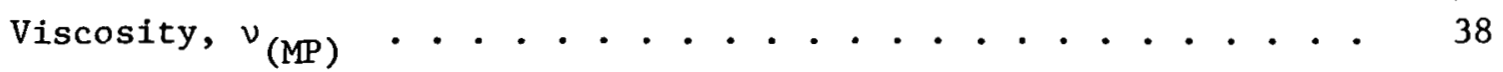

THORIUM DICARBIDE $\left(\mathrm{ThC}_{2}\right)$..................... . . 39

Melting Point................... 39

Boiling Point . . . . . . . . . . . . . . . . 39

Enthalpy, $\mathrm{H}_{(\mathrm{MP})}{ }^{-\mathrm{H}_{(298)}}$. . . . . . . . . . . . 39

Heat of Fusion, $\Delta_{\mathrm{m}}$. . . . . . . . . . . . . . . . 39

Heat of Vaporization, $\Delta \mathrm{H}_{\mathrm{V}}$. . . . . . . . . . . . . 39

Heat Capacity, $\mathrm{C}_{\mathrm{p}}$. . . . . . . . . . . . . . 39

Heat Capacity, $\mathrm{c}_{\mathrm{p}}^{(\mathrm{s})}{ }_{\mathrm{MP})}$. . . . . . . . . . . . . . . . 39

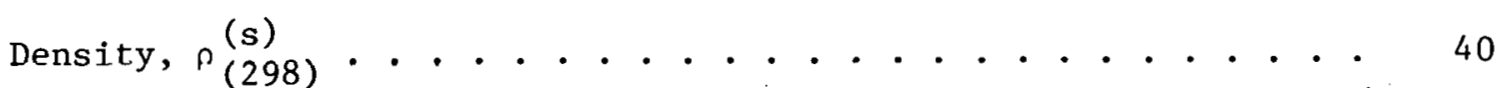

Density, $\rho(s)($ MP) . . . . . . . . . . . . . . . . 40

Volumetric Thermal Expansion Coefficient, $\bar{\alpha}_{(298-M P)}^{(s)} \cdot$. . . . . 40

Temperature of Phase Transitions . . . . . . . . . . . 40

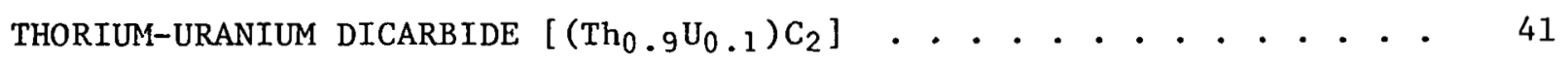

Melting Point ..................... . 41

Enthalpy, H ${ }_{(\mathrm{MP})}{ }^{-\mathrm{H}_{(298)}}$. . . . . . . . . . . 41

Heat of Fusion, $\Delta_{\mathrm{m}}$. . . . . . . . . . . . . . . . 41

Heat Capacity, $\mathrm{c}_{\mathrm{p}_{(298)}}$. . . . . . . . . . . . . . 41

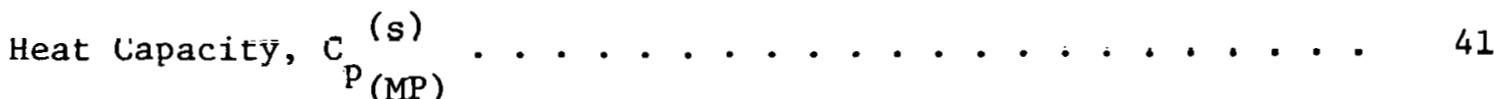

Therma1 Conductivity, $\mathrm{K}_{(298)}$. . . . . . . . . . . . . 41

Density, ${ }_{(298)}^{(s)}$. . . . . . . . . . . . . . . . . 41

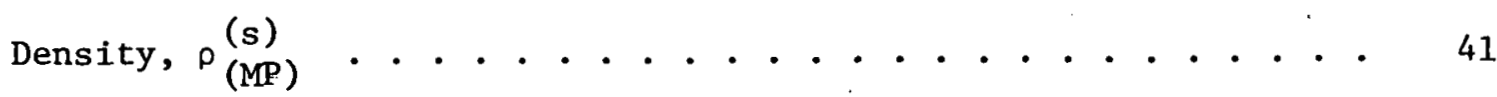


Volumetric Thermal Expansion Coefficient, $\bar{\alpha} \frac{(s)}{(298-M P)} \cdot$. . . . . 41 URANIUM DICARBIDE $\left(\mathrm{UC}_{2}\right)$

Melting Point...................... 42

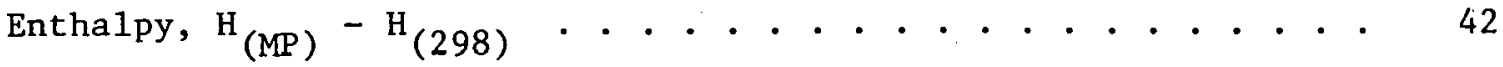

Heat of Fusion, $\Delta_{\mathrm{m}}$. . . . . . . . . . . . . . . . . 42

Heat Capacity, $\mathrm{C}_{\mathrm{p}}$. . . . . . . . . . . . . . 42

Heat Capac1гy, $\mathrm{c}_{\mathrm{p}}^{(\mathrm{s})}$. . . . . . . . . . . . . . . . 42

Detsity, o $(2), \ldots 8)$. . . . . . . . . . . . . . . . . . 42

Density, ${ }_{(\mathrm{MP})}^{(\mathrm{s})}$. . . . . . . . . . . . . . . . . . 42

Volumetric Thermal Expansion Coefficient, $\bar{\alpha}_{(298-M P)}^{(s)} \cdot . . . . .44$

APPENDIX . . . . . . . . . . . . . . . . . . . . . . 43

REFERENCES . . . . . . . . . . . . . . . . . . . . . . . 4 49 


\section{LIST OF FIGURES}

No.

1. Vapor Pressure vs. Temperature for Thorium and Uranium . . . . . . 44

2. Heat Capacity vs. Temperature for $\mathrm{ThO}_{2}$ and $\mathrm{UO}_{2}$. . . . . . . . . 45

3. Enthalpy vs. Temperature for $\mathrm{ThO}_{2}$ and $\mathrm{UO}_{2}$. . . . . . . . . 46

4. Vapor Pressure vs. Temperature for $\mathrm{ThO}_{2}$ and $\mathrm{UO}_{2}$. . . . . . . . . 47

5. Pressure vs. Enthalpy for $\mathrm{ThO}_{2}$ and $\mathrm{UO}_{2}$. . . . . . . . . . . 48 


\section{LIST OF TABLES}

No.

Title

Page

1a. Thermophysical Properties of Metals and Alloys . . . . . . . . 4

1b. Thermophysical Properties of Oxides . . . . . . . . . . . 5

1c. Thermophysical Properties of Carbides . . . . . . . . . . . 6

2. Measurements of the Melting Point of Thorium . . . . . . . 8

3. Measurements of Melting Point of Uranium . . . . . . . . 13

4. Temperature Range of Fnthalpy and Heat Capncity Measuremente for Uranium ...................... 13

5. Heat of Vaporization of Uranium . . . . . . . . . . . . 14

6. Heat Capacity of the $\gamma$ Phase of Uranium . . . . . . . . . . 15

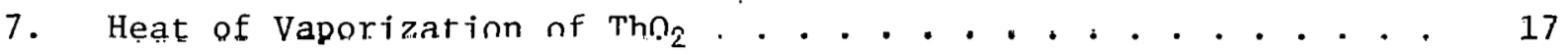

8. Measurements of the Average Coefficient of Linear Expansion . . 31

9. Density Measurements of Andrew and Latimer . . . . . . . . 37

10. Temperatures of the Phase Transitions of $\mathrm{ThC}_{2}$. . . . . . . . 40 


\section{THERMOPHYSICAL PROPERTIES OF THORIUM AND URANIUM \\ SYSTEMS FOR USE IN REACTOR SAFETY ANALYSIS}

by

Joanne K. Fink, Martin G. Chasanov, and Leonard Leibowitz

\section{INTRODUCTION}

The data presented in this compilation are intended to serve as a preliminary set of thermophysical property values for use by workers engaged in reactor safety analyses of the $\mathrm{Th}-{ }^{233} \mathrm{U}$ reactor concept. The data were obtained from currently available reviews and data collections. The primary sources of information are given in Refs. 1-4. In some cases, when data were not available and we thought that the results were justifiable, we have provided "best" estimates of the values for these properties. In such cases, the estimation techniques are discussed. Work is in progress to provide error estimates for cases in which that information is now lacking. These estimates will be included in future revisions of this report.

It should be clear from this compilation that much experimental work needs to be done to provide a firm data base for reactor calculations involving thorium-uranium systems. We plan to update this initial effort by continuing our search of the literature for new data and by applying appropriate theoretical methods to the estimation of additional data for these systems. In the interim, we believe that the material presented here will enable designers and analysts to make computations that should provide reasonable results.

In this compilation, we have included the thermophysical properties of various thorium, uranium, and thorium-uxanium systems. Following each recommended value of a property there is a discussion which includes the methods of estimation, equations used, sources of the calculations, and the experimental sources.

First, the thermophysical properties of $\mathrm{Th}, \mathrm{U}$, and $\mathrm{Th}_{0.9} \mathrm{U}_{0.1}$ are discussed; then the properties of $\mathrm{ThU}_{2}, \mathrm{UU}_{2}$, and $\left(\mathrm{Th}_{0.9} \mathrm{U}_{0.1}\right) \mathrm{O}_{2}$; and flindly Llie properties of the mono and dicarbides of $T h$, $U$, and $T h_{0.9} U_{0.1}$. The ratio of $0.9 \mathrm{Th}$ to $0.1 \mathrm{U}$ was chosen for the mixed thorium-uranium system because that was the best estimate of an appropriate ratio at the time this report was compiled. Since it is realized that other ratios are likely to be considered, the method used to obtain values for the mixture has been explained in the discussion of each property. Thus, the reader may calculate the value of a property for a different ratio by using the appropriate method for the cases in which the value has been calculated and not obtained by experimental measurement.

The properties of $\left(\mathrm{Pu}_{0.2} \mathrm{U}_{0.8}\right) \mathrm{O}_{2}$ and of $\left(\mathrm{Pu}_{0.2} \cdot \mathrm{U}_{0.8}\right) \mathrm{C}$ have also been included, in appropriate order, since these have been considered as reactor fuels in many reactor safety analyses; thus, comparisons of their properties with those of $\left(\mathrm{Th}_{0.9} \mathrm{U}_{0.1}\right) \mathrm{O}_{2}$ and $\left(\mathrm{Th}_{0.9} \mathrm{U}_{0.1}\right) \mathrm{C}$ may be desired. This comparison by the analyst may serve to give him an insight into the efferts he can expect in his calculations and computer codes in changing from the $\mathrm{Pu}_{0 .}{ }_{2} \mathrm{U}_{0.8}$ system to the $\mathrm{Th}_{0.9} \mathrm{U}_{0.1}$ system. 
To aid in the comparison of properties of uranium systems and thorium systems, five graphs have been included in the appendix. These graphs include comparisons of enthalpy, heat capacity and vapor pressure of $\mathrm{ThO}_{2}$ and $\mathrm{UO}_{2}$. Plots of the vapor pressure of Th and $\mathrm{U}$ as a function of temperature are also included.

For the user's convenience in comparison of properties and for quick reference, three tables summarizing the values of thermophysical properties discussed in the compilation are included below. The order of the properties and materials in the tables follows the order in the text. Table la gives the thermophysical properties of the metals: Th, Th0.9 $\mathrm{U}_{0.1}$, and $\mathrm{U}$. The properties of the oxides $\mathrm{ThO}_{2},\left(\mathrm{Th}_{0.9} \mathrm{U}_{0.1}\right) \mathrm{O}_{2}, \mathrm{UO}_{2}$, and $\left(\mathrm{Pu}_{0.2} \mathrm{U}_{0.8}\right) \mathrm{O}_{2}$ are given in Table 1b. The last table, Table lc, contains the properties of monocarbides and dicarbides: ThC, $\left(\mathrm{Th}_{0.9} \mathrm{U}_{0,1}\right) \mathrm{C}, \mathrm{UC},\left(\mathrm{Pu}_{0.2} \mathrm{U}_{0.8}\right) \mathrm{C}, \mathrm{ThC}_{2}$, $\left(' l^{\prime} h_{0.9} \mathrm{U}_{0.1}\right) \mathrm{C}_{2}$, and $\mathrm{UC}_{2}$. The values of properties that are in roman type are values obtained by experimental measurements. Those values that are in italics have been obtalned by calc11.ation or an estimation technique which is explained in the appropriate section of the text. The symbols used in Tables la, $b$, and $c$, and throughout the body of the report, are defined as follows:

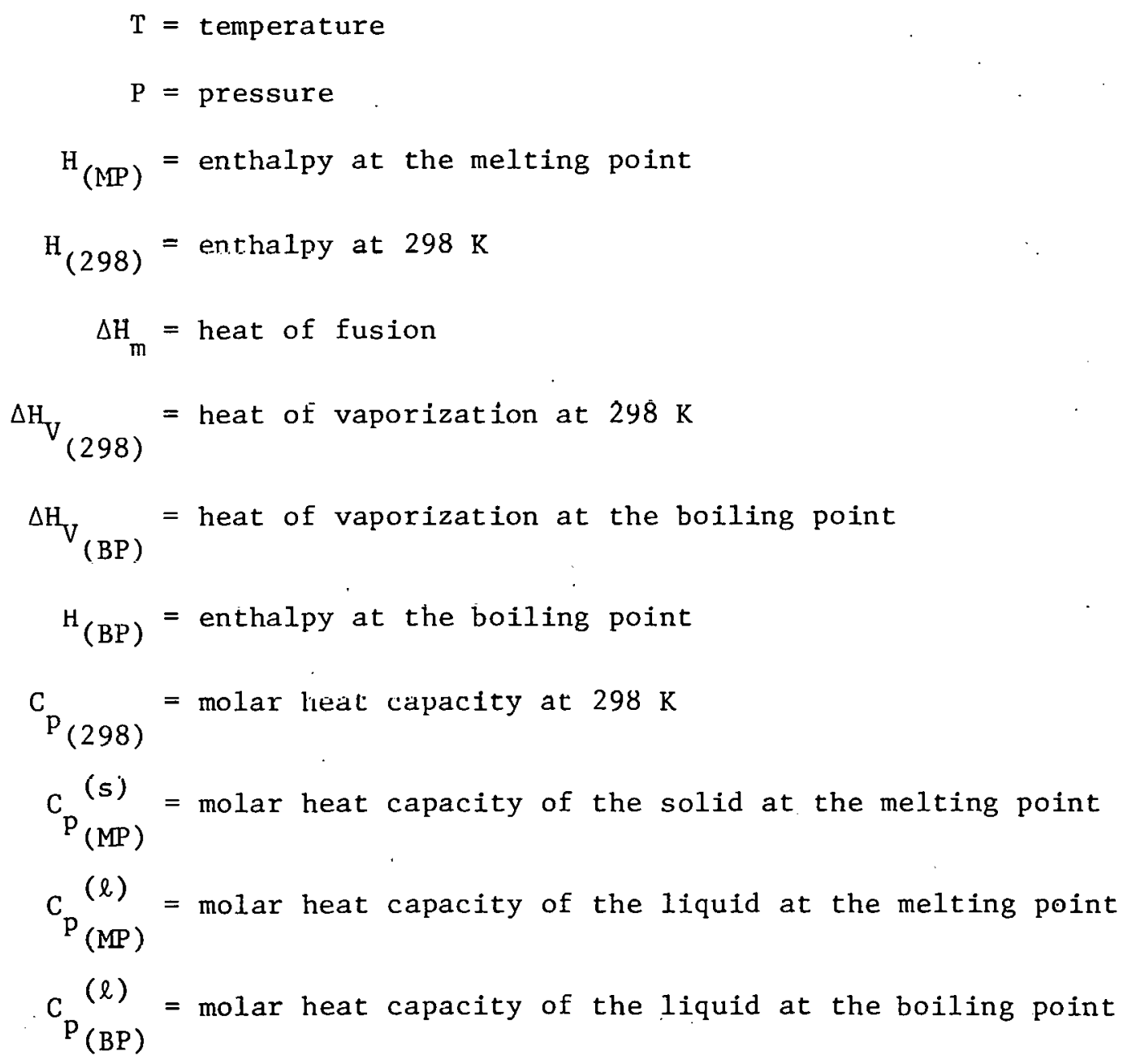




$$
\begin{aligned}
& \mathrm{K}_{(298)}^{(\mathrm{s})}=\text { thermal conductivity at } 298 \mathrm{~K} \\
& K_{(M P)}^{(s)}=\text { thermal conductivity of the solid at the melting point } \\
& \mathrm{K}_{(\mathrm{MP})}^{(\ell)}=\text { thermal conductivity of the liquid at the melting point } \\
& K_{(B P)}^{(\ell)}=\text { thermal conductivity of the liquid at the boiling point } \\
& \varepsilon_{\mathrm{T}}=\text { normal total emissivity } \\
& \varepsilon_{(0.65 \mu \mathrm{m})}=\text { normal spectral emissivity at } 0.65 \mu \mathrm{m} \\
& \rho(s)=\text { density of the solid at } 298 \mathrm{~K} \\
& \rho(s)=\text { density of the solid at the melting point } \\
& \left(-\frac{\Delta \rho}{\rho}\right)_{M P}=\text { fractional change in density on melting } \\
& \rho(\ell)=\text { density of the liquid at the boiling point } \\
& \bar{\alpha}^{(s)}=\text { average volumetric expansion coefficient of the solid } \\
& \begin{aligned}
\bar{\alpha}_{(M P)}^{(\ell)}= & \text { average volumetric expansion coefficient of the liquid } \\
& \text { at the melting point }
\end{aligned} \\
& \kappa_{S}=\text { adiabatic compressibility } \\
& \kappa_{T}=\text { isothermal compressibility } \\
& v_{(M P)}=\text { viscosity of the liquid at the melting point } \\
& \sigma=\text { surface tension }
\end{aligned}
$$


Table 1a. Thermophysical Properties of Metals and Alloys

\begin{tabular}{|c|c|c|c|}
\hline Property & Th & $\mathrm{Th}_{0.9 .} \mathrm{U}_{0.1}$ & $\mathrm{u}$ \\
\hline Melting Point (K) & $2023 \pm 15$ & 1815 & 1408 \\
\hline Bolling Poịt (K) & 4975 & 4892 & 4427 \\
\hline Critical Temp. (K) & - & - & - \\
\hline Critical Pressure (Pa) & - & - & - \\
\hline $\mathrm{H}_{(\mathrm{MP})}-\mathrm{H}_{(298)}(\mathrm{kJ} / \mathrm{mol})$ & 62.22 & 60.92 & 49.20 \\
\hline$\Delta \mathrm{H}_{\mathrm{m}}(\mathrm{kJ} / \mathrm{mol})$ & $13.8 \pm 1.2$ & 10.9 & 9.1 \\
\hline $\mathrm{H}_{(B P)}-\mathrm{H}_{(298)}(\mathrm{kJ} / \mathrm{mol})$ & $2 i 1.7$ & 210.5 & 205.0 \\
\hline$\Delta \mathrm{H}_{(298)}(\mathrm{kJ} / \mathrm{mol})$ & $397.1 \pm 13$ & 536 & $531_{-4}^{+8}$, \\
\hline$\Delta \mathrm{H}_{\mathrm{V}}(\mathrm{BP})(\mathrm{kJ} / \mathrm{mol})$ & - & - & - \\
\hline $\mathrm{C}_{\mathrm{p}_{(298)}}(\mathrm{J} / \mathrm{K} \cdot \mathrm{mol})$ & $27.32 \pm 0.29$ & 27.36 & 27.66 \\
\hline $\mathrm{C}_{\mathrm{P}_{(M P)}}^{(\mathrm{s})}(\mathrm{J} / \mathrm{K} \cdot \mathrm{mol})$ & 39.87 & 39.7 & 38.28 \\
\hline$C_{P_{(M P)}}^{(\mathcal{(})}(\mathrm{J} / \mathrm{K} \cdot \mathrm{mo} 1)$ & 46 & 46.4 & 48.66 \\
\hline$e_{P_{(B P)}}^{(R)}\left(J / R^{2}+1 n U\right)$ & - & - & - \\
\hline $\mathrm{K}_{(298)}(\mathrm{W} / \mathrm{m} \cdot \mathrm{K})$ & 49.1 & 46 & 27.6 \\
\hline$K_{(M P)}^{(s)}(W / m \cdot k)$ & - & - & - \\
\hline$K_{(M P)}^{(l)}(W / m \cdot K)$ & - & - & - \\
\hline$K_{(B P)}^{(\ell)}(W / m \cdot K)$ & - & - & - \\
\hline$\varepsilon_{T}$ & - & - & - \\
\hline${ }^{f}(0.65 \mu \mathrm{m})$ & - & - & - \\
\hline $0_{(298)}^{(s)}\left(\mathrm{kg} / \mathrm{m}^{3}\right)$ & $1.17 \times 10^{4}$ & $1.24 \times 10^{\prime \prime}$ & $1.90 \times 10^{4}$ \\
\hline$\rho_{(M P)}^{(s)}\left(\mathrm{kg} / \mathrm{m}^{3}\right)$ & $1.10 \times 10^{4}$ & $1.16 \times 10^{4}$ & $1.74 \times 10^{4}$ \\
\hline$\left(-\frac{\Delta \rho}{\rho}\right)_{\mathbb{R} \mathbb{P}}$ & - & - & - \\
\hline$\rho_{(\mathrm{BP})}^{(l)}\left(\mathrm{kg} / \mathrm{m}^{3}\right)$ & - & - & - \\
\hline $\bar{\alpha}_{(298-M P)}^{(s)}\left(K^{-1}\right)$ & $3.5 \times 10^{-5}$ & - & $\begin{array}{l}6 \times 10^{-5}(\alpha) \\
5 \times 10^{-5}(\beta) \\
7 \times 10^{-5}(\gamma)\end{array}$ \\
\hline $\bar{u}_{(\mathbb{P P})}^{(l)}\left(K^{-1}\right)$ & - & - & - \\
\hline $\mathrm{K}_{s}\left(\mathrm{~Pa}^{-1}\right)$ & - & - & - \\
\hline $\mathrm{K}_{\mathrm{T}}\left(\mathrm{Pa}^{-1}\right)$ & - & - & - \\
\hline$\nu_{(\mathrm{MP})}(\mathrm{Pa} \cdot \mathrm{s})$ & - & - & - \\
\hline$\sigma(N / m)$ & - & - & - \\
\hline $\begin{array}{l}\text { T of Phase } \\
\text { Transitions (K) }\end{array}$ & $1633 \pm 10(\alpha \rightarrow B)$ & - & $\begin{array}{c}940.9 \pm 1(\alpha \rightarrow \beta) \\
1048.0 \pm 1.6(\beta+\gamma)\end{array}$ \\
\hline
\end{tabular}


Table 1b. Thermophysical Properties of Oxides

\begin{tabular}{|c|c|c|c|c|}
\hline Property & $\mathrm{ThO}_{2}$ & 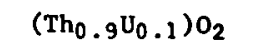 & $\mathrm{vo}_{2}$ & $\left(\mathrm{U}_{0.8} \mathrm{Pu}_{0.2}\right)_{2}$ \\
\hline Melting Point (K) & $3643 \pm 30$ & 3500 & $3138 \pm 15$ & $\begin{array}{l}3063(\ell) \\
3023(8)\end{array}$ \\
\hline Bolling Point (K) & 4320 & 4250 & $3760 \pm 200$ & 3520 \\
\hline Critical Temp., (K) & - & - . & - & - \\
\hline Critical Pressure ( $\mathrm{Pa})$ & - & - & - & - \\
\hline$H_{(M P)}-H_{(298)}(k J / m o l)$ & 290.4 & 265.6 & 310.0 & 282.5 \\
\hline$\Delta \mathrm{H}_{\mathrm{m}}(\mathrm{kJ} / \mathrm{mol})$ & 90.8 & 87.4 & $74.9 \pm 1.2$ & $74.9 \pm 1.2$ \\
\hline$H_{(B P)}-H_{(298)}(k J / m o l)$ & 484.1 & 471.1 & 469.4 & 425.5 \\
\hline$\Delta \mathrm{V}_{(298)}(\mathrm{kJ} / \mathrm{mol})$ & $664.0 \pm 10.5$ & 602 & 598 & 619 \\
\hline$\Delta \mathrm{H}_{\mathrm{V}_{(\mathrm{BP})}}(\mathrm{kJ} / \mathrm{mol})$ & - & - & $454 \pm 53$ & $536 \pm 54$ \\
\hline $\mathrm{C}_{\mathrm{P}_{(298)}}(\mathrm{J} / \mathrm{K} \cdot \mathrm{mol})$ & 61.7 .3 & 64.27 & 63.6 & 69.6 \\
\hline $\mathrm{C}_{\mathrm{p}_{(\mathrm{MP})}}^{(\mathrm{s})}(\mathrm{J} / \mathrm{K} \cdot \mathrm{mol})$ & 103.2 & 95 & 208.4 & 173.3 \\
\hline $\mathrm{C}_{\mathrm{P}}^{(\mathrm{l})}(\mathrm{lP})$ & 136.0 & $136 . c$ & 136.0 & 136.0 \\
\hline$C_{\left.P_{(B P}\right)}^{(l)}(\mathrm{J} / \mathrm{K} \cdot \mathrm{mol})$ & 136.0 & 136.0 & 136.0 & 136.0 \\
\hline$K_{(298)}(W / m \cdot K)$ & 13.2 & 11.1 & 8.4 & 6.3 \\
\hline$K_{(M P)}^{(s)}(W / m \cdot K)$ & - & - & - & - \\
\hline$K_{(M P)}^{(l)}(W / m \cdot K)$ & - & - & - & - \\
\hline $\mathrm{K}_{(\mathrm{BP})}^{(\mathrm{l})}(\mathrm{W} / \mathrm{m} \cdot \mathrm{K})$ & - & - & - & - \\
\hline$\varepsilon_{T}$ & - & - & - & - \\
\hline${ }^{\varepsilon}(0.65 \mu \mathrm{m})$ & - & - & $0.87 \pm 0.1$ & $0.87 \pm 0.1$ \\
\hline$\rho_{(298)}^{(s)}\left(\mathrm{kg} / \mathrm{m}^{3}\right)$ & $(1.0013 \pm 0.0001) \times 10^{4}$ & $1.009 \times 10^{4}$ & $1.097 \times 10^{4}$ & $1.108 \times 10^{4}$ \\
\hline$\rho_{(\mathrm{MP})}^{(\mathrm{s})}\left(\mathrm{kg} / \mathrm{m}^{3}\right)$ & $8.8 \times 10^{3}$ & $8.8 \times 10^{3}$ & y. $/ 1 \times 10^{3}$ & $9.88 \times 10^{3}$ \\
\hline$\left(-\frac{\Delta \rho}{\rho}\right)_{\mathrm{MP}}$ & 0.11 & 0.11 & 0.11 & 0.11 \\
\hline$\rho_{(B P)}^{(l)}\left(\mathrm{kg} / \mathrm{m}^{3}\right)$ & - & - & - & - \\
\hline$\overline{\bar{n}}(\mathrm{~s})(2 y \dot{\mathrm{Z}-M Y})\left(\mathrm{K}^{-1}\right)$ & $3.5 \times 10^{-5}$ & $3.5 \times 10^{-5}$ & $4.5 \times 10^{-5}$ & $4.5 \times 10^{-5}$ \\
\hline $\bar{\alpha}_{(\mathbf{M P})}^{(l)}\left(K^{-1}\right)$ & $9 \times 10^{-5}$ & $9 x 10^{-5}$ & $9 \times 10^{-5}$ & $9 \times 10^{-5}$ \\
\hline${ }^{k}(\mathrm{~s})\left(\mathrm{Pa}^{-1}\right)$ & - & - & - & - \\
\hline $\mathrm{K}_{\mathrm{T}}\left(\mathrm{Pa}^{-1}\right)$ & - & - & - & - \\
\hline$v_{(\mathrm{MP})}(\mathrm{Pa} \cdot \mathrm{s})$ & $(4.30 \pm 0.1) \times 10^{-3}$ & $(4.30 \pm 0.1) \times 10^{-3}$ & $(4.30 \pm 0.1) \times 10^{-3}$ & $(4.30 \pm 0.1) \times 10^{-3}$ \\
\hline$\sigma(N / m)$ & - & - & $0.45 \pm 0.04$ & $0.45 \pm 0.04$ \\
\hline $\begin{array}{l}\text { T of Phase } \\
\text { Transitions }(\mathrm{K})\end{array}$ & - & - & . & - \\
\hline
\end{tabular}


Table 1c. Thermophysical Properties of Carbides

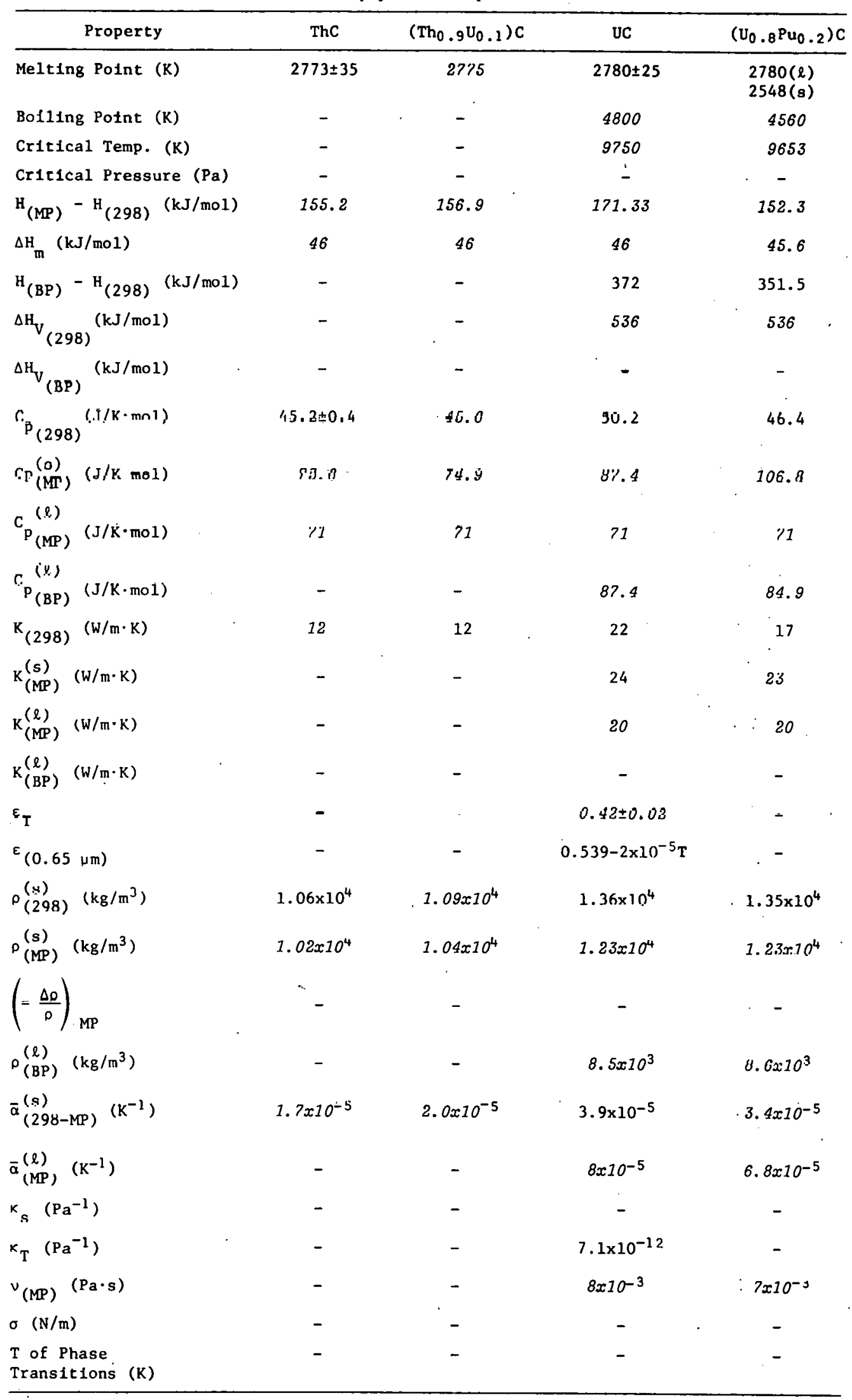


Table 1c. (Cont'd.)

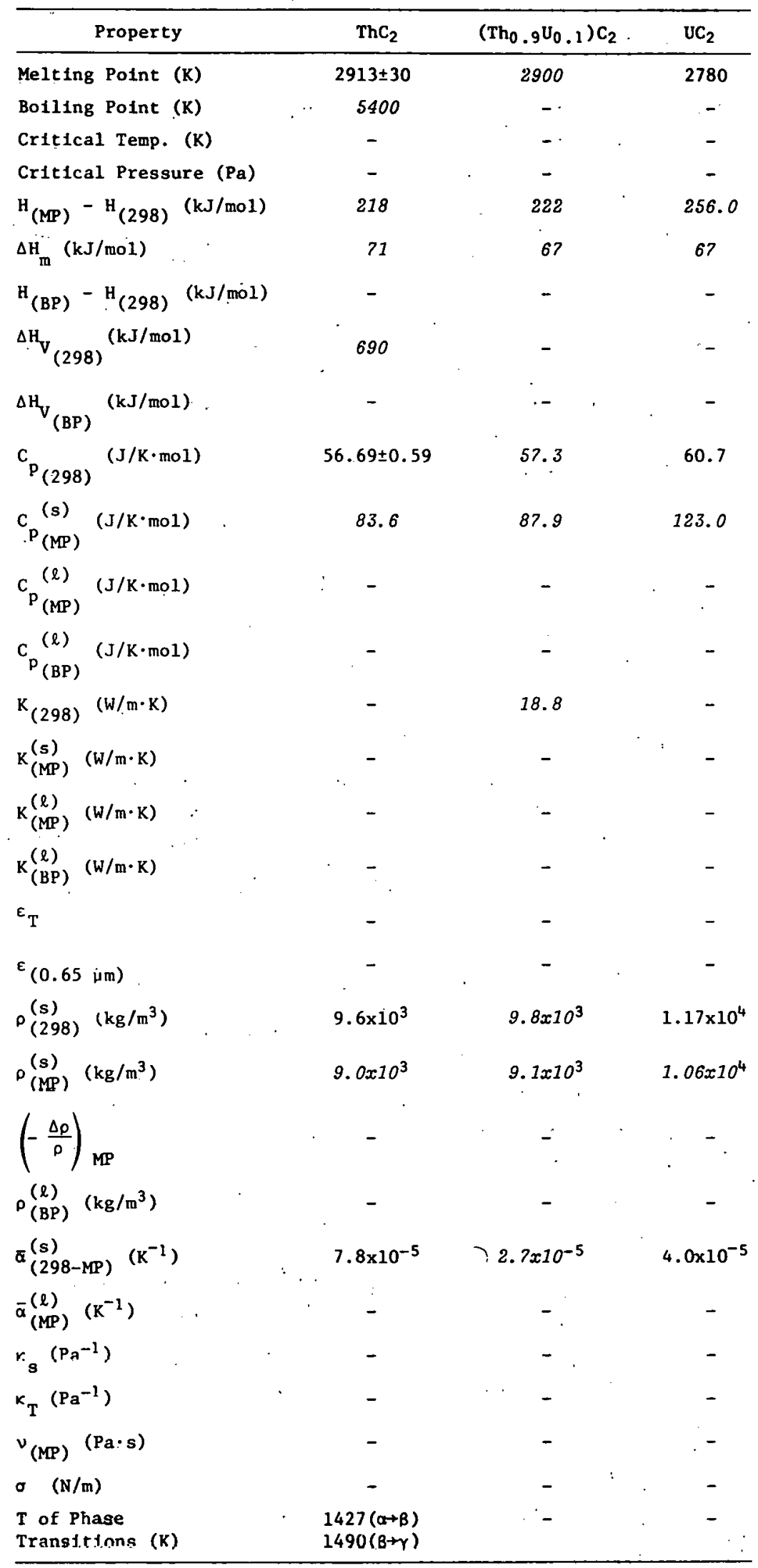


THORIUM (Th)

Melting Point: $\quad 2023 \pm 15 \mathrm{~K}$

This is a weighted average from five experiments. ${ }^{l}$ The experimental values are tabulated below.

Table 2. Measurements of the Melting Point of Thorium

\begin{tabular}{llc}
$\begin{array}{l}\text { Melting } \\
\text { Point, K }\end{array}$ & \multicolumn{1}{c}{ Experimenter } & Ref. \\
\hline 2020 & Ackermann and Rauh (1972) & 5 \\
2027 & Benz, Hoffman, and Rupert (1967) & 6 \\
2028 & Chiott1 and Gill (1961) & 7 \\
2033 & Eash and Carlson (1960) & 8 \\
2028 & Korbitz (1964) & 9 \\
\hline
\end{tabular}

Boiling Point: $4975 \mathrm{~K}$

This is the value recommended in Ref. 1 .

Enthalpy, $\mathrm{H}_{(\mathrm{MP})}-\mathrm{H}_{(298)}: \quad 62.22 \mathrm{~kJ} / \mathrm{mol}$

This value ${ }^{1}$ is based on experiments of Levinson ${ }^{10}$ from 1269 to $2100 \mathrm{~K}$.

His are the only experiments to temperatures above the melting point.

Inconsistencies exist between the high temperature enthalpy data of various experimenters.

Heat of Fusion, $\Delta \mathrm{H}_{\mathrm{m}}: \quad 13.8 \pm 1.2 \mathrm{~kJ} / \mathrm{mol}$

This is an experimental value from experiments of Levinson. 10

Enthalpy, $\mathrm{H}_{(\mathrm{BP})}-\mathrm{H}_{(298)}: \quad 211.7 \mathrm{~kJ} / \mathrm{mol}$

This value is from tabulated values of enthalpy given in Ref. 1. The enthalpy of Th has been measured only to $2100 \mathrm{~K}$. ${ }^{10}$

Heat of Vaporization, $\Delta \mathrm{H}_{(298)}: \quad 597.1 \pm 13 \mathrm{~kJ} / \mathrm{mol}$

This value was calculated by Ackermann and Rauh ${ }^{11}$ from their vapor pressure measurements in the temperature range from 2020 to $2500 \mathrm{~K}$. Their equation for the log of the pressure is

$$
\log \mathrm{P}(\mathrm{atm})=-(29770 \pm 218) / \mathrm{T}+(6.024 \pm 0.098)
$$

converted to SI units, it becomes

$$
\log P(\mathrm{~Pa})=-(29770 \pm 218) / \mathrm{T}+(11.030 \pm 0.098)
$$


These data were selected over other data because the authors gave a complete description of the role of oxygen contamination and because their data showed no variation in $\Delta \mathrm{H}_{\mathrm{V}}$ when calculated by either the second or the third law method.

Heat Capacity, $C_{p_{(298)}}: \quad 27.32 \pm 0.29 \mathrm{~J} / \mathrm{K} \cdot \mathrm{mol}$

This value, recommended in Ref. 1, is from calorimetric measurements by Griffel and Skochdapole. ${ }^{12}$ Rand $^{2}$ gives the following equation, which we have converted to SI units, for calculating heat capacity of the $\alpha$ phase for the temperature range from 298 to $1633 \mathrm{~K}$ :

$$
\mathrm{C}_{\mathrm{p}}(\alpha \text { phase })(\mathrm{J} / \mathrm{K} \mathrm{mo} 1)=25.48+7.82 \times 10^{-3} \mathrm{~T}-0.510 \times 10^{5} \mathrm{~T}^{-2}
$$

This equation gives the value $27.24 \mathrm{~J} / \mathrm{K} \cdot \mathrm{mol}$ at $298 \mathrm{~K}$.

Heat Capacity, $\mathrm{C}_{\mathrm{P}}^{(\mathrm{SP})}{ }^{(\mathrm{sP})}: \quad 39.87 \mathrm{~J} / \mathrm{K} \cdot \mathrm{mol}$

This value is based on drop calorimetric measurements by Levinson on $B$-phase thorium in the temperature range from 1667 to $1991 \mathrm{~K} .{ }^{10}$ His are the only experiments in this temperature region. High-temperature heat capacity data in the $\alpha$ phase are not completely consistent. ${ }^{1}$ Rand $^{2}$ gives the following equation, which we have converted to SI units, for calculating heat capacity in the $\beta$ phase for the temperature range from 1633 to $2023 \mathrm{~K}$ :

$$
\mathrm{C}_{\mathrm{p}}(B \text { phase })(\mathrm{J} / \mathrm{K} \mathrm{mol})=15.69+11.97 \times 10^{-3} \mathrm{~T}
$$

This equation gives $30.90 \mathrm{~J} / \mathrm{K}$ mol at $2023 \mathrm{~K}$.

Heat Capacity, $\mathrm{c}_{\mathrm{p}_{(\mathrm{MP})}}^{(\ell)}: \quad 46.0 \mathrm{~J} / \mathrm{K} \cdot \mathrm{mol}$

This value, taken from Ref. 1 , is based only on two measurements of liquid enthalpy by Levinson. 10

Thermal Conductivity, $\mathrm{K}_{(298)}: \quad 49.1 \mathrm{~W} / \mathrm{m} \cdot \mathrm{K}$

This is the value recommended by Touloukian ${ }^{13}$ and is based on an evaluation of six sets of measurements by nine authors. Measurements range from $5.3 \mathrm{~K}^{13 \mathrm{a}}$ to $923 \mathrm{~K} .13 \mathrm{~b}$

Density, $\rho(2): \quad 1.17 \times 10^{4} \mathrm{~kg} / \mathrm{m}^{3}$

This value, cited by Ferro, ${ }^{2}$ is based on the identical density values measured by James and Straumanis ${ }^{14}$ and calculated by Wyckoff ${ }^{15}$ from lattice parameters.

Density, $\rho \stackrel{(\mathrm{s})}{(\mathrm{MP})}: \quad 1.10 \times 10^{4} \mathrm{~kg} / \mathrm{m}^{3}$

This value was calculated by us using the thermal expansion coefficients tabulated by Touloukian. 13 
Volumetric Thermal Expansion Coefficient, $\bar{\alpha}_{(298-\mathrm{MP})}^{(\mathrm{s})}: \quad 3.5 \times 10^{-5} \mathrm{~K}^{-1}$

This value was taken from the compilation by Touloukian. ${ }^{3}$ It is based on his analysis of 17 sets of data by seven authors. Measurements have been made to $1273 \mathrm{~K} .15 \mathrm{a}$

Phase Transition, $\alpha \rightarrow \beta: \quad 1633 \pm 10 \mathrm{~K}$

Experimental values ${ }^{16-21}$ for the $\alpha-$ to- $\beta$ phase transition range from 1603 to $1678 \mathrm{~K}$. The differences are believed due to impurities in the samples. The selected value ${ }^{l}$ is based on experimental data of Chiotti and Gill 7 and experimental data of Takeuchi et al., 20 who both extrapolated the transition temperature to zero carbon content, and from experiments of McMasters and Larsen. 18 


\section{Melting Point: $1815 \mathrm{~K}$}

This value was taken from the thorium-uranium phase diagram. ${ }^{2}$ The solidusliquidus curve is due to Ackermann and Rauh. ${ }^{5}$

Boiling Point: $\quad 4892 \mathrm{~K}$

The boiling point of the mixture was calculated by us. The value given is the temperature at which the total pressure of the mixture equals 1 atm. The total pressure was determined from the partial pressures by means of the equation

$$
P=\sum_{i} P_{i} X_{i}
$$

where

$$
\begin{aligned}
& x_{i}=\text { the mole fraction of the } i^{\text {th }} \text { component } \\
& P_{i}=\text { the pressure of the } i^{\text {th }: \text { component }}
\end{aligned}
$$

The maximum temperature at which the vapor pressures of $U$ and of $T h$ have been measured ${ }^{11}, 22$ is $2500 \mathrm{~K}$. Therefore, large extrapolations were needed to reach the boiling point. These were made by assuming that an equation of the form

$$
\log \mathrm{P}=\mathrm{A} / \mathrm{T}+\mathrm{B}
$$

was applicable over the entire temperature range of interest.

Enthalpy, $\mathrm{H}_{(\mathrm{MP})}-\mathrm{H}_{(298)}: \quad 60.92 \mathrm{~kJ} / \mathrm{mol}$

The value $60.92 \mathrm{~kJ} / \mathrm{mol}$ is a molar average* calculated by us. No experimental data exist.

Heat of Fusion, $\Delta \mathrm{H}_{\mathrm{m}}: \quad 10.9 \mathrm{~kJ} / \mathrm{mol}$

A molar average was calculated by us since no experimental data exist.

Enthalpy, $\mathrm{H}_{(\mathrm{BP})}-\mathrm{H}_{(298)}: \quad 210.5 \mathrm{~kJ} / \mathrm{mol}$

A molar average was calculated from our estimates for the pure components. No data exist for the alloy.

* In many cases, no data are available for mixtures. In these cases, a mular average value calculated from the pure components was used. This will be referred to simply as "molar average." 
Heat of Vaporization, $\Delta \mathrm{H}_{(298)}:: 536 \mathrm{~kJ} / \mathrm{mol}$

The heat of vaporization was determined from the slope of a curve of $10 \mathrm{~g}$ $\mathrm{P}$ vs. $1 / \mathrm{T}$, where $\mathrm{P}=$ pressure and $\mathrm{T}=$ temperature. Vapor pressure measurements ${ }^{11}, 22$ have been made to $2500 \mathrm{~K}$ for $\mathrm{U}$ and $\mathrm{Th}$.

Heat Capacity, $\mathrm{C}_{\mathrm{P}_{(298)}}: \quad 27.36 \mathrm{~J} / \mathrm{K} \cdot \mathrm{mol}$

Since there are no experimental measurements of heat capacity of $\mathrm{Th}_{0.9} \mathrm{U}_{0.1}$, a molar average is given for the heat capacity.

Heat Capacicy, $\mathrm{C}_{\mathrm{P}}^{(\mathrm{s})} \mathrm{MP}^{(\mathrm{s})}: \quad 39.7 \mathrm{~J} / \mathrm{K} \cdot \mathrm{mol}$

This is a molar average. No experimental data exist.

Heàt Capacity, $\mathrm{C}_{\mathrm{p}}^{(\mathrm{MP})}=-46.4 \mathrm{~J} / \mathrm{K} \cdot \mathrm{mol}$

This is a molar average. No experimental data exist.

Thermal Conductivity, $\mathrm{K}_{(298)}: \quad 46 \mathrm{~W} / \mathrm{m} \cdot \mathrm{K}$

This value was calculated assuming that the reciprocals of thermal conductivities of the components are additive. ${ }^{13}$ Thus, the equation used was

$$
\frac{1}{\mathrm{~K}(\mathrm{ThU})}=\frac{x}{\mathrm{~K}(\mathrm{U})}+\frac{(1-\mathrm{x})}{\mathrm{K}(\mathrm{Th})}
$$

where $x=$ the mole fraction of $U$ in ThU.

Density, $\rho(\mathrm{s}), \quad 1.24 \times 10^{4} \mathrm{~kg} / \mathrm{m}^{3}$

This is a molar average. The density of $\mathrm{Th}_{n} . \mathrm{g} \mathrm{U}_{\mathrm{n}} \mathrm{l}$ at $298 \mathrm{~K}$ has not been measured.

Density, $\stackrel{(\mathrm{s})}{\mathrm{(MP)}}: \quad 1.16 \times 10^{4} \mathrm{~kg} / \mathrm{m}^{3}$

The density given is a molar average. No experimental data exist. 
URANIUM (U)

Melting Point: $\quad 1408 \pm 2 \mathrm{~K}$

This value was recommended ${ }^{l}$ on the basis of five experiments showing excellent agreement. The experimental values are given in Table 3 .

Table 3. Measurements of Melting Point of Uranium

\begin{tabular}{cclr}
\hline $\begin{array}{l}\text { Melting } \\
\text { Point, } \mathrm{K}\end{array}$ & $\begin{array}{c}\text { Temperature } \\
\text { Scale }\end{array}$ & \multicolumn{1}{c}{ Experimenter } & Ref. \\
\hline $1405.5 \pm 0.8$ & IPTS-1948 & Blumenthal & 23 \\
1406 & IPTS-1948 & Buzzard et al. & 24 \\
$1405.5 \pm 10$ & IPTS-1948 & Udy and Boulger & 25 \\
$1406 \pm 2$ & IPTS-1948 & Dah1 and Cleaves & 26 \\
$1408 \pm 1$ & IPTS-1968 & Ackermann and Rauh & 5 \\
\hline
\end{tabular}

Boiling Point: $\quad 4427 \mathrm{~K}$

The boiling point of $U$ was taken to be the temperature at which the vapor pressure equals $1 \mathrm{~atm}$. Since vapor pressure measurements of $U$ have been made only to $2500 \mathrm{~K}, 22$ extrapolations were performed by us assuming a constant heat of vaporization.

Enthalpy, $\mathrm{H}_{(\mathrm{MP})}-\mathrm{H}_{(298)}: \quad 49.20 \mathrm{~kJ} / \mathrm{mol}$

Enthalpy and heat capacity measurements at various temperatures have been made by several investigators, as shown in Table 4.

The change in enthalpy given above is taken from a table in Ref. 1 . The values in that table were chosen to agree with the $\alpha$-phase data of Ginnings and Corruccini ${ }^{28}$ and to reproduce measured enthalpy increments for the $\beta$ and $\gamma$ phases.

Table 4. Temperature Range of Enthalpy and Heat Capacity Measurements for Uranium

\begin{tabular}{clc}
\hline $\begin{array}{c}\text { Temperature } \\
\text { Ralige, } \mathrm{K}\end{array}$ & \multicolumn{1}{c}{ Experimenter } & Ref. \\
\hline 2981300 & Moore and Kcllcy & 27 \\
$298-1178$ & Ginnings and Corruccini & 28 \\
$373-1073$ & North & 29 \\
$413-1454$ & Savage and Seibel & 30 \\
$323-873$ & Mit'kina & 31 \\
$1205-1579$ & Levinson & 32 \\
$1.428-2.348$ & Stephens & 33 \\
\hline
\end{tabular}


Heat of Fusion, $\Delta \mathrm{H}_{\mathrm{m}}: \quad 9.1 \mathrm{~kJ} / \mathrm{mol}$

This value is based on an experiment by Stephens ${ }^{33}$ which gave a value of $9.142 \mathrm{~kJ} / \mathrm{mol}$ for the heat of fusion. Levinson ${ }^{32}$ measured the heat of fusion to be $(8.326 \pm 0.544) \mathrm{kJ} / \mathrm{mol}$. The value by Stephens was selected ${ }^{1}$ because of the extensive range of his experiments 1428-2348 $\mathrm{K}$ and because he avolded problems of contamination by using levitation calorimetry.

Enthalpy, $\mathrm{H}_{(\mathrm{BP})}-\mathrm{H}_{(298)}: \quad 205.0 \mathrm{~kJ} / \mathrm{mol}$

This value is from tabulated values of enthalpy given in Ref. 1. Enthalpy experiments have been performed to $2348 \mathrm{~K}$ by Stephens. ${ }^{33}$ The equation given by Stephens to $\mathrm{fit}$ his data in the temperature range $1728-2348 \mathrm{~K}$ (converted to SI units) is

$$
\mathrm{H}_{\mathrm{T}}-\mathrm{H}_{(298)}(\mathrm{J} / \mathrm{mol})=48.66 \mathrm{~T}-1.014 \times 10^{4}
$$

lleat of VaporizaLilon, $\wedge \mathrm{H}_{\mathrm{V}}: \quad 531_{-4}^{+8} \mathrm{~kJ} / \mathrm{mol}$

The value $531_{-4}^{+8} \mathrm{~kJ} / \mathrm{mol}$ for the heat of vaporization at $298 \mathrm{~K}$ is the value recommended by the IAEA Panel on the uranium-plutonium carbide system. It is recommended in Ref. 1 as being the value most compatible with all the data on uranium systems. Many experiments on uranium vapor pressure have been performed, with the highest temperature $(2500 \mathrm{~K})$ being investigated by Ackermann and Rauh. ${ }^{22}$ Table 5 gives the value of the heat of vaporization at 0 and $298 \mathrm{~K}$ from the various experiments.

Table 5. Heat of Vaporization of Uranium

\begin{tabular}{crlcr}
\hline$\Delta \mathrm{H}_{\mathrm{V}}, \mathrm{k}, \mathrm{l} / \mathrm{m} \mathrm{I}$ & $\mathrm{T}, \mathrm{K}$ & \multicolumn{1}{c}{ Experimenter } & Year & Ref. \\
\hline $487.8 \pm 0.4$ & 0 & Rauh and Thorn & 1954 & 34 \\
$527 \pm 21$ & 0 & DeMaria et al. & 1960 & 35 \\
487.4 & 298 & Alcock and Grieveson & $1961-1962$ & 36 \\
$525.1 \pm 10.5$ & 298 & Drowart et al. & 1965 & 37 \\
$511.6 \pm 5.4$ & 298 & Leitnaker and Godfrey & 1967 & 38 \\
529.3 & 298 & Storms & 1967 & 39 \\
$537.6 \pm 8$ & 298 & Pattoret et al. & 1968 & 40 \\
$539.7 \pm 8$ & 298 & Pattoret et al. & 1969 & 41 \\
$528.4 \pm 4.2$ & 298 & Ackermann et al. & 1961 & 42 \\
530.1 & 298 & Ackermann and Rauh & 1972 & 43 \\
$536 \pm 8$ & 298 & Oetting and Leitnaker & 1972 & 44 \\
\hline
\end{tabular}

Heat Capacity, $\mathrm{C}_{\mathrm{p}_{(298)}}:=27.66 \mathrm{~J} / \mathrm{K} \cdot \mathrm{mol}$

This value, from Ref. 1 , is based on the heat capacity measurements of Flowtow and Lohr ${ }^{45}$ and those of Flowtow and Osborne. ${ }^{46}$ 
Heat Capacity, $\mathrm{C}_{\mathrm{P}}^{(\mathrm{sP})}:{ }^{(\mathrm{s})}: \quad 38.28 \mathrm{~J} / \mathrm{K} \cdot \mathrm{mol}$

The value for the heat capacity of solid uranium at the melting point is that recommended in Ref. 1 . It is the constant value of heat capacity for the $\gamma$ phase determined from experiments of Ginnings and Corruccini. ${ }^{28}$ Table 6 gives the reported values for heat capacity of the $\gamma$ phase of uranium.

Table 6. Heat Capacity of the $\gamma$ Phase of Uranium

\begin{tabular}{llr}
\hline $\mathrm{C}_{\mathrm{p}}(\gamma$-phase $)$ & & \\
$\mathrm{J} / \mathrm{K} \cdot \mathrm{mol}$ & \multicolumn{1}{c}{ Experimenter } & Ref. \\
\hline 38.07 & Moore and Kelley & 27 \\
38.28 & Ginnings and Corruccini & 28 \\
40.08 & Levinson & 32 \\
\hline
\end{tabular}

Heat Capacity, $\mathrm{C}_{\mathrm{p}}^{(\mathrm{MP})}: \quad 48.66 \mathrm{~J} / \mathrm{K} \cdot \mathrm{mol}$

The recommended ${ }^{1}$ heat capacity of liquid uranium at the melting point is the constant value for liquid uranium from experiments of Stephens. ${ }^{33}$

Thermal Conductivity, $\mathrm{K}_{(298)}: \quad 27.6 \mathrm{~W} / \mathrm{m} \cdot \mathrm{K}$

This is the value recommended by Touloukian. ${ }^{13}$ It is based on his analysis of 109 sets of measurements by 36 experiments from $2.5 \mathrm{~K}^{46 \mathrm{a}}$ to $1173 \mathrm{~K} .46 \mathrm{~b}$

Density, $\rho(2): \quad 1.90 \times 10^{4} \mathrm{~kg} / \mathrm{m}^{3}$

The value of density of uranium at $298 \mathrm{~K}$ is that recommended by the Joint Committee on Powder Diffraction Patterns. 47

Volumetric Thermal Expansion Coefficient, $\bar{\alpha}_{(298-\mathrm{MP})}^{(\mathrm{s})}: \begin{aligned} & 6 \times 10^{-5} \mathrm{~K}^{-1} \text { ( } \alpha \text { phase) } \\ & 5 \times 10^{-5} \mathrm{~K}^{-1} \text { ( } \beta \text { phase) }\end{aligned}$

$7 \times 10^{-5} \mathrm{~K}^{-1} \quad(\gamma$ phase $)$

There are the values recommended by Touloukian, ${ }^{13}$ who analyzed data from 0 to $1373 \mathrm{~K}^{48}$ from 48 experiments.

Temperature of Phase Transitions: $\quad \alpha \rightarrow \beta, 940.9 \pm 1 \mathrm{~K}$

$\beta \rightarrow \gamma, 1048.0 \pm 1.6 \mathrm{~K}$

These values are taken from experiments by Blumentha1. ${ }^{23}$ Although many investigators have reported values for these transitions, their data are often uncertain because of impurities in their samples or undercooling effects, or because the primary purpose of the experiment was not the phase transition temperature. Blumenthal's values are believed the most reliable because he did a careful study using high-purity electrolytic uranium and circumvented the problems of hysteresis, superheating, and undercooling. ${ }^{1}$ 
THORIA $\left(\mathrm{ThO}_{2}\right)$

Melting Point: $\quad 3643 \pm 30 \mathrm{~K}$

The value $3643 \pm 30 \mathrm{~K}$ is recommended by $\mathrm{Rand}^{2}$ and based on the following experimental information. Benz ${ }^{49}$ recommends, in his phase diagram, a value of $3663 \mathrm{~K}$. for the melting point of $\mathrm{ThO}_{2}$. Experiments by Lambertson et al. ${ }^{50}$ on the $\mathrm{ThO}_{2}-\mathrm{UO}_{2}$ system gave melting points for $\mathrm{ThO}_{2}$ ranging from 3558 to $3828 \mathrm{~K}$, a result of variable contamination from the container. When these results were extrapolated to pure thoria, a value of $3623 \mathrm{~K}$ was obtained. However, Lambertson recommended a somewhat lower value, $3573 \mathrm{~K}$, for the melting point to allow for curvature in the $\mathrm{ThO}_{2}$ end of the system as was found with $\mathrm{UO}_{2}$. However, this curvature in the $\mathrm{UO}_{2}$ system is believed due to excess oxygen and thus would not occur in the ThO $\mathrm{O}_{2}$ system. Rand therefore gave greater weight to the higher values.

\section{Boiling Point: $4320 \mathrm{~K}$}

The bolling point was calculated by us from extrapolated vapor-pressure data. The maximum temperature of vapor-pressure experiments is $2800 \mathrm{~K} .51$

Enthalpy, $H_{(M P)}-\mathrm{H}_{(398)}: \quad 290.4 \mathrm{~kJ} / \mathrm{mol}$

The values given in Ref. 2 (p. 35, Table 7) for the heat capacity were used by us to extrapolate to the melting point. From those values, the enthalpy to the melting point was calculated. Experimental enthalpy data are available up to $2773 \mathrm{~K} .52$

Heat of Fusion, $\Delta \mathrm{H}_{\mathrm{m}}: \quad 90.8 \mathrm{~kJ} / \mathrm{mol}$

This value was calculated by us assuming that the heat of fusion $=n R$, where $\mathrm{n}$ is the number of atoms per molecule of the compound. However, the value may be too low if the heat capacity of the $\mathrm{ThO}_{2}$ does not increase as melting is approached, as does the heat capacity of $\mathrm{UO}_{2}$. See Fig. 2 in the appendix.

Enthalpy, $\mathrm{H}_{(\mathrm{RP})}-\mathrm{H}_{(298)}: \quad 484.1 \mathrm{~kJ} / \mathrm{mol}$

This value was calculated by us using $\mathrm{H}_{(\mathrm{MP})}-\mathrm{H}_{(298)}$ and the heat of fusion value (given above) and then extrapolating to the bojling point using nur estimated value for the heat capacity of liquid $\mathrm{ThO}_{2}$.

Heat of Vaporization, $\Delta \mathrm{H}_{(298)}:=664.0 \pm 10.5 \mathrm{~kJ} / \mathrm{mol}$

This value, recommended in Ref. 3, is from experiments by Ackermann et al.53 Tabulated below are the available values of heat of vaporization at $298 \mathrm{~K}$ derived from the temperature dependence of vapor pressure measurements. 
Table 7. Heat of Vaporization of $\mathrm{ThO}_{2}$

\begin{tabular}{clll}
\hline $\begin{array}{c}\Delta \mathrm{H}_{(298)}, \\
\mathrm{kJ} / \mathrm{mol}\end{array}$ & $\begin{array}{l}\text { Temperature Range } \\
\text { of Experiments, } \mathrm{K}\end{array}$ & \multicolumn{1}{c}{ Experimenter } & Ref. \\
\hline $664: 0 \pm 10.5$ & $2180-2865$ & Ackermann et al. & 53 \\
715 & $2050-2250$ & Shapiro & 54 \\
712.5 & $2398-2677$ & Hoch and Johnston & 55 \\
770 & $2040-2320$ & Fan & 56 \\
\hline
\end{tabular}

Heat Capacity, $\mathrm{C}_{\mathrm{P}_{(298)}}: \quad 61.73 \mathrm{~J} / \mathrm{K} \cdot \mathrm{mol}$

The heat capacity data for thoria are very consistent. The recommended ${ }^{2}$ value for $C_{P_{2}}$ is taken from experiments by Osborne and Westrum, 57 who measured heat capacity from 10 to $305 \mathrm{~K}$. It also agrees exactly with the value calculated from an equation given by Godfrey et al. ${ }^{59}$ to fit the data of Osborne and Westrum, ${ }^{57}$ Victor and Douglas $58 \mathrm{a}$ (323-1173) $\mathrm{K}$, Southard $58 \mathrm{~b}(522-1786 \mathrm{~K})$, and Hoch and Johnston ${ }^{52}(1456-2753 \mathrm{~K})$. This equation, converted to SI units, is

$$
\mathrm{C}_{\mathrm{P}}(\mathrm{J} / \mathrm{K} \cdot \mathrm{mol})=69.29+9.339 \times 10^{-3} \mathrm{~T}-9.184 \times 10^{5} \mathrm{~T}^{-2}
$$

for the temperature range 298 to $3000 \mathrm{~K}$.

Heat Capacity, $\mathrm{C}_{\mathrm{P}}^{(\mathrm{sP})}{ }^{(\mathrm{sP})}: \quad 103.2 \mathrm{~J} / \mathrm{K} \cdot \mathrm{mol}$

Heat capacity and enthalpy measurements for $\mathrm{ThO}_{2}$ have been performed only to: $2773 \mathrm{~K} .52$ In the regions of experimental overlap, there is excellent agreement. By fitting the available experimental data, Godfrey et al. ${ }^{8}$ obtained Eq. 9, as described above. The above value for heat capacity at the melting point $(103.4 \mathrm{~T} / \mathrm{K} \cdot \mathrm{mol})$ was found by extrapolating to the melting point the values of heat capacity given in Ref. 2 (p. 35, Table 7). The tabulated values are represented by Eq. 9 .

Heat Capacity, $\mathrm{C}_{\mathrm{P}}^{(\mathrm{MP})}{ }^{(\ell)}: \quad 136.0 \mathrm{~J} / \mathrm{K} \cdot \mathrm{mol}$

No data exist. The value is assumed to be equal to that of $\mathrm{UO}_{2}$.

Heat Capacity, $\mathrm{C}_{\mathrm{P}}^{(\mathrm{BP})}{ }^{(\ell)}: \quad 136.0 \mathrm{~J} / \mathrm{K} \cdot \mathrm{mol}$

No data exist. The value is assumed to be equal to that of $\mathrm{UO}_{2}$. measured at lower temperatures. 
Thermal Conductivity, $\mathrm{K}_{(298)}: \quad 13.2 \mathrm{~W} / \mathrm{m} \cdot \mathrm{K}$

This value is recommended by Touloukian. 13 It is based on 10 sets of data by seven authors. The temperatures of measurements range from $304 \mathrm{~K}^{59}$ to $2009 \mathrm{~K} .60$

Density, $\rho(2):(1.0013 \pm 0.0001) \times 10^{4} \mathrm{~kg} / \mathrm{m}^{3}$

This value, from Ref. 2 (Table XXIV on page 199), is based on the lattice parameters of Skinner. ${ }^{61}$

Density, $\rho(\mathrm{s}): \quad 8.8 \times 10^{3} \mathrm{~kg} / \mathrm{m}^{3}$

This is an extrapolated value. ${ }^{3}$ The maximum temperature of experiments is $2700 \mathrm{~K} .62$

Change in Density on Melting, $\left(-\frac{\Delta \rho}{\rho}\right)_{\mathrm{MP}}: \quad 0.11$

No data exist. The value is assumed equal to that of $\mathrm{vO}_{2}$.

Volumetric Thermal Expansion Coefficient, $\bar{\alpha}^{(\mathrm{s})}: \quad 3.5 \times 10^{-5} \mathrm{~K}^{-1}$

This value is from thermal expansion measurements by Hoch and Momin. ${ }^{62}$ Their equation for percent 1 inear thermal expansion for solid $\mathrm{Tl}_{1} \mathrm{O}_{2}$ is

$(100 \%) \times \frac{\left(\mathrm{L}_{\mathrm{T}}-\mathrm{L}_{25}\right)}{\mathrm{L}_{\mathrm{T}}}=8.383 \times 10^{-4} \mathrm{~T}+0.995 \times 10^{-7} \mathrm{~T}^{2}-2.106 \times 10^{-2}$

where $\mathrm{T}$ is given in ${ }^{\circ} \mathrm{C}$.

Volumetric Thermal Expansion Coefficient, ${ }_{(\text {MP) }}^{(\ell)}: \quad 9 \times 10^{-5} \mathrm{~K}^{-1}$

No data exist. The value is assumed equal to that of $\mathrm{UO}_{2}$.

Viscosity, ${ }_{(M P)}: \quad(4.30 \pm 0.10) \times 10^{-3} \mathrm{~Pa} \cdot \mathrm{s}$

No data exist. The value is assumed equal to that of uo 2 . 
Melting Point: $\quad 3500 \mathrm{~K}$

This value was taken by us from a $\mathrm{plot}^{3}$ of melting point vs. composition for stoichiometric ( $\mathrm{Th}, \mathrm{U}) \mathrm{O}_{2}$ from data from experiments of Lambertson et a ${ }^{6} 63$ and Christensen. ${ }^{64}$

Boiling Point: $\quad 4250 \mathrm{~K}$

The maximum temperature of reported vapor pressure experiments is $2800 \mathrm{~K} .51$ The boiling point was calculated by us from extrapolated vapor pressure data. The vapor pressure values were corrected using the heat of vaporization obtained from our estimated heat of fusion at the melting point. The boiling point was taken as the temperature at which the vapor pressure equals $1 \mathrm{~atm}$. The equation used to determine the total pressure from the partial pressures, previously presented as Eq. 5, is as follows:

$$
P=\sum_{i} P_{i} X_{i}
$$

where

$$
\begin{aligned}
& \mathrm{P}_{i}=\text { the pressure of the } 1^{\text {th }} \text { component } \\
& \mathrm{X}_{i}=\text { the mole fraction of the } i^{\text {th }} \text { component }
\end{aligned}
$$

Enthalpy, $\mathrm{H}_{(\text {MP })}-\mathrm{H}_{(298)}: \quad 265.6 \mathrm{~kJ} / \mathrm{mol}$

Experimental enthalpy data exist only to $2270 \mathrm{~K} .65$ The value given above was calculated by us. An estimate of the enthalpy at the melting point was obtained by applying the enthalpy equation formulated by Springer et $a$. ${ }^{65}$ to fit their experimental data from $273 \mathrm{~K}$ through $2270 \mathrm{~K}$ :

$$
\begin{aligned}
\mathrm{H}_{(\mathrm{T})}-\mathrm{H}_{(298)(\mathrm{J} / \mathrm{mol})=} & -2.3502 \times 10^{4}+69.96 \mathrm{~T} \\
& +35.925 \times 10^{-11} \mathrm{I}^{2}+6.957 \times 10^{5} \mathrm{~T}^{-1}
\end{aligned}
$$

where $\mathrm{T}$ is temperature $\mathrm{K}$. For comparison, a molar average of the $\mathrm{ThO}_{2}$ and $\mathrm{UO}_{2}$ enthalpy differences gives a value of $291.2 \mathrm{~kJ} / \mathrm{mol}$; therefore, the estimate appears reasonable.

Heat of Fusion, $\Delta \mathrm{H}_{\mathrm{m}}: \quad 87.4 \mathrm{~kJ} / \mathrm{mol}$

This value is a salculated molar average. No data exist for $\mathrm{Th}_{0.9} \mathrm{~g}_{0.1} \mathrm{O}_{2}$. Enthalpy, $\mathrm{H}_{(\mathrm{BP})}-\mathrm{H}_{(298)}: \quad 471.1 \mathrm{~kJ} / \mathrm{mol}$

This value is a calculated molar average. Enthalpy measurements for $\mathrm{Th}_{0 .} \mathrm{g}_{0.1} \mathrm{O}_{2}$ have been made only to $2270 \mathrm{~K} .65$ 
Heat of Vaporization, $\Delta \mathrm{H}_{(298)}: \quad 602 \mathrm{~kJ} / \mathrm{mol}$

The heat of vaporization was determined from the slope of the in P vs. 1/T curve where $\mathrm{P}=$ pressure and $\mathrm{T}=$ temperature. The maximum temperature of the vapor pressure data is $2800 \mathrm{~K} .51$

Heat Capacity, $C_{\mathrm{P}_{(298)}}: \quad 64.27 \mathrm{~J} / \mathrm{K} \cdot \mathrm{mol}$

This value was calculated from the equation

$$
C_{p}=69.96+7.185 \times 10^{-3} \mathrm{~T}-6.957 \times 10^{5} \mathrm{~T}^{-2}(\mathrm{~J} / \mathrm{K} \cdot \mathrm{mol})
$$

where $\mathrm{T}$ is temperature in degree Kelvin. The squation was deriver by Springer et $a 2 .{ }^{8} \mathrm{~J}$ by a least squares $\mathrm{fit}$ of their experimental enthalpy data from 273 to $2270 \mathrm{~K}$.

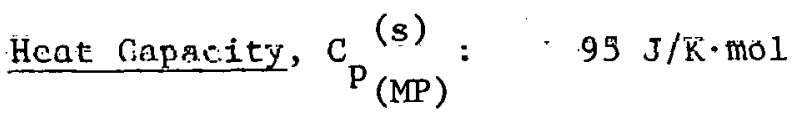

This yalue was estimated by extrapolating the data of Springer et a .55 lo the melting point, using Eq. 12, given above. For comparison, a molar average of the heat capacities of $\mathrm{ThO}_{2}$ and $\mathrm{UO}_{2}$ gives $113.8 \mathrm{~J} / \mathrm{K} \cdot \mathrm{mol}$; therefore, extrapolation appears reasonable.

Heat Capacity, $\mathrm{C}_{\mathrm{P}}^{(\mathrm{MP})}{ }^{(\ell)}: \quad 136.0 \mathrm{~J} / \mathrm{K} \cdot \mathrm{mol}$

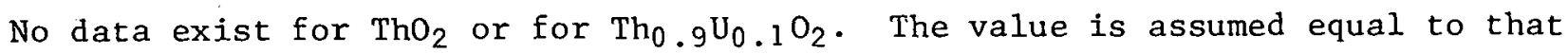
of $\mathrm{UO}_{2}$.

Heat Caprisity, $C_{p_{(B P)}}^{(l)} ; \quad 136.0 \mathrm{~J} / \mathrm{K} \cdot \mathrm{mol}$

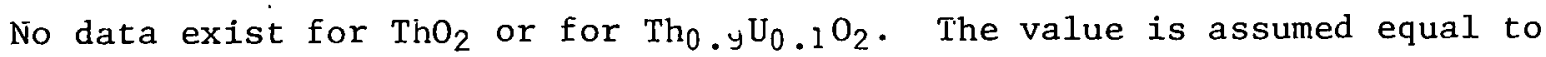
that of $\mathrm{UO}_{2}$.

'Therma $\perp$ Conductivity, $\mathrm{K}_{(298)}$ : $\quad 11.1 \mathrm{~W} / \mathrm{m} \cdot \mathrm{K}$

This value was obtained for $\left(\mathrm{Th}_{0 .} \mathrm{g}_{0.1}\right) \mathrm{O}_{2}$ of $100 \%$ theoretical density, from the equation

$\mathrm{K}(\mathrm{W} / \mathrm{m} \cdot \mathrm{K})=\left\{\left[\frac{(1-\mathrm{P})(0.67+0.282 \mathrm{U})}{0.67+0.282 \mathrm{U}+\mathrm{P}(1+0.092 \mathrm{U})}\right]\right.$

$$
\left.\mathrm{x}\left[\frac{1}{0.79(1+0.09 \mathrm{U})+0.0185 \mathrm{~T}}\right]\left(\frac{1+0.291 \mathrm{UJ}}{1+0.400 \mathrm{U}}\right)\right\} \times 10^{2}
$$


where $\mathrm{P}=$ the fractional porosity and $\mathrm{U}=$ the weight percent of $\mathrm{UO}_{2}$; this equation was derived by Springer et al. 65 to fit their experimental data from $500-2200 \mathrm{~K}$. The thermal conductivity of $(\mathrm{Th}, \mathrm{U}) \mathrm{O}_{2}$ is sensitive to sample preparation and composition. Below $1300 \mathrm{~K}$, there is wide variation in the data. ${ }^{3}$ Below $500 \mathrm{~K}$, reported experimental values differ by as much as a factor of 10 .

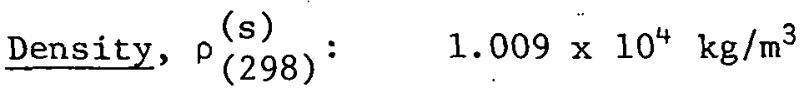

The value given here, recommended in Ref. 3, is from measurements by Cohen and Berman. ${ }^{66}$ Variations exist among reported values of lattice parameters and densities for $(\mathrm{Th}, \mathrm{U}) \mathrm{O}_{2}$. These discrepancies are probably due to variations in purity or stoichiometry.

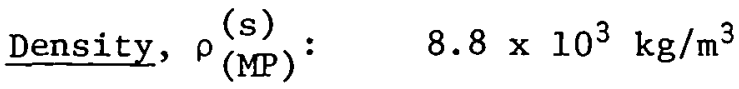

The value is assumed equal to the value for $\mathrm{ThO}_{2}$. No data exist.

Change in Density on Melting, $\left(-\frac{\Delta \rho}{\rho}\right)_{\mathrm{MP}}^{:} \quad 0.11$

No data exist for $\mathrm{ThO}_{2}$ or for the mixed oxide. The value is assumed equal

to that of $\mathrm{UO}_{2}$.

Volumetric Thermal Expansion Coefficient, $\bar{\alpha}_{(298-\mathrm{MP})}^{(\mathrm{s})}: \quad 3.5 \times 10^{-5} \mathrm{~K}^{-1}$

The value is assumed equal to that for $\mathrm{ThO}_{2}$. The thermal expansion of $\mathrm{Th}_{0.9} \mathrm{U}_{0.1} \mathrm{O}_{2}$ has been determined to $2270 \mathrm{~K}$ by Springer et al. 65 In the region from $298 \mathrm{~K}$ to $2270 \mathrm{~K}$, the thermal expansion coefficient of $\mathrm{Th}_{0.9} \mathrm{U}_{0.1} \mathrm{O}_{2}$ is quite close to that of $\mathrm{ThO}_{2}$. At $2270 \mathrm{~K}$, it differs by less than.. $3 \%$.

The difference in thermal expansion decreases as the temperature increases.

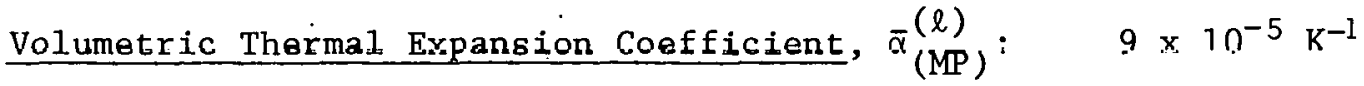

No data exist for the mixed oxide or for $\mathrm{ThO}_{2}$. The value is assumed equal to that of $\mathrm{UO}_{2}$.

Viscosity, $v_{(\mathrm{MP})}: \quad(4.30 \pm 0.10) \times 10^{-3} \mathrm{~Pa} \cdot \mathrm{s}$

No data exist for the mixed oxide or for $\mathrm{ThO}_{2}$. The value is assumed equal to that of $\mathrm{UO}_{2}$. 
URANIA (UO2)

Melting Point: $\quad 3138 \pm 15 \mathrm{~K}$

This value based on experiments of Latta and Fryxel1 ${ }^{67}$ has been recommended by Leibowitz et al. ${ }^{4}$ because it is the most recent and most accurate of thermal arrest measurements. It agrees within experimental error with earlier experiments of Lyon and Bailey. ${ }^{68}$

Boiling Point: $\quad 3760 \pm 200 \mathrm{~K}$

This value was calculated by Leibowitz et al. ${ }^{4}$ from vapor pressure data. Experiments have been performed to $3500 \mathrm{~K} .69$

Enthalpy, $\mathrm{H}_{(\mathrm{MP})}-\mathrm{H}_{(298)}: \quad 310.0 \mathrm{~kJ} / \mathrm{mol}$.

The value was taken from tabulated enthalpy values in Ref. 4. It is based on the equation (which we have converted to SI units)

$\left.\Delta \mathrm{H}_{(298)}(\mathrm{J} / \mathrm{mol})=\mathrm{K}_{1} \theta\left[\mathrm{e}^{\theta / \mathrm{T}}-1\right)^{-1}-\left(e^{\theta / 298}-1\right)^{-1}\right]$

$$
+K_{2}\left[T^{2}-(298)^{2}\right]+K_{3} e^{-E_{D} / R T}
$$

where

$$
\begin{aligned}
\mathrm{T} & =\text { temperature, in } \mathrm{K} \text { from } 298-3137 \mathrm{~K} \\
\theta & =535 \mathrm{~K} \\
\mathrm{E}_{\mathrm{D}} & =157.69 \mathrm{~kJ} / \mathrm{mol} \\
\mathrm{K}_{1} & =80.08 \mathrm{~J} / \mathrm{mul} \cdot \mathrm{K} \\
\mathrm{K}_{2} & =3.28 \times 10^{-3} \mathrm{~J} / \mathrm{mol} \cdot \mathrm{K}^{2} \\
\mathrm{~K}_{3} & =2.36 \times 10^{7} \mathrm{~J} / \mathrm{mol}
\end{aligned}
$$

derived by Kerrisk and Clifton 70 to fit the most reliable $\mathrm{UO}_{2}$ enthalpy data. $27,71-74$

Heat of Fusion, $\Delta \mathrm{H}_{\mathrm{m}}: \quad 74.9 \pm 1.2 \mathrm{~kJ} / \mathrm{mol}$

This is an average value ${ }^{4}$ from measurements of Chikalla, ${ }^{75}$ Leibowitz et al., ${ }^{73}$ and Hein and Flagella. ${ }^{76}$ All three experimental values agree within experimental error.

Enthalpy, $\mathrm{H}_{(\mathrm{BP})}-\mathrm{H}_{(298)}: \quad 469.4 \mathrm{~kJ} / \mathrm{mol}^{4}$

This value is extrapolated by us from tabulated enthalpy values in Ref. 4. Experimental measurements go to $3500 \mathrm{~K} .{ }^{73}$ 
Heat of Vaporization, $\Delta \mathrm{H}_{(298)}: \quad 598 \mathrm{~kJ} / \mathrm{mol}$

This value is from experimental data of Tetenbaum and Hunt. ${ }^{77}$

Heat of Vaporization, $\Delta \mathrm{H}_{(B P)}: \quad 454 \pm 53 \mathrm{~kJ} / \mathrm{mol}$

This value, recommended by Leibowitz et $a Z,{ }^{4}$ is based on $\mathrm{UO}_{2}$ vapor pressuretemperature data. Experiments go to $3500 \mathrm{~K} .69$

Heat Capacity, $\mathrm{C}_{\mathrm{P}_{(298)}}: \quad 63.6 \mathrm{~J} / \mathrm{K} \cdot \mathrm{mol}$

This value is highly recommended by Leibowitz et al. ${ }^{4}$ It is calculated from an equation of Kerrisk and Clifton 70 and is also in good agreement with the most reliable experimental data. $27,71-74$

Heat Capacity, $\mathrm{C}_{\mathrm{p}_{(\mathrm{MP})}^{(\mathrm{s})}:}^{(\mathrm{s})} \quad 208.4 \mathrm{~J} / \mathrm{K} \cdot \mathrm{mol}$

This value is from tabulated heat capacities given in Ref. 4. It is calculated from the following equation (which we have converted to SI units), derived by Kerrisk and Clifton ${ }^{70}$ from enthalpy data: $27,71-74$

$$
C_{p}=\frac{K_{1} \theta^{2} e^{\theta / T}}{T^{2}\left(e^{\theta / T}-1\right)^{2}}+2 K_{2} T+\frac{K_{3} E_{D}}{R T^{2}} e^{-E_{D} / R T}
$$

where

$$
\begin{aligned}
\mathrm{T} & =\text { temperature in } \mathrm{K} \text { from } 298-3137 \mathrm{~K} \\
\theta & =535 \mathrm{~K} \\
\mathrm{E}_{\mathrm{D}} & =157.69 \mathrm{~kJ} / \mathrm{mol} \\
\mathrm{K}_{1} & =80.08 \mathrm{~J} / \mathrm{mol} \cdot \mathrm{K} \\
\mathrm{K}_{2} & =3.28 \times 10^{-3} \mathrm{~J} / \mathrm{mol} \cdot \mathrm{K}^{2} \\
\mathrm{~K}_{3} & =2.36 \times 10^{7} \mathrm{~J} / \mathrm{mol}
\end{aligned}
$$

(l)

Heat Capacity, $\mathrm{C}_{\mathrm{P}_{(\mathrm{MP})}}: \quad 136.0 \mathrm{~J} / \mathrm{K} \cdot \mathrm{mol}$

This value, given in Ref. 4, is from experimental enthalpy data for liquid UO $_{2}$ by Leibuwilz et $\alpha Z{ }^{7}{ }^{8}$ The enthalpy data of Hcin and Flagella 76 for liquid $\mathrm{UO}_{2}$ is in good agreement. 
Heat Capacity, $\mathrm{C}_{\mathrm{P}}^{(\mathrm{BP})}: \quad 136.0 \mathrm{~J} / \mathrm{mol} \cdot \mathrm{K}$

This value, recommended by Leibowitz et $a l .,^{4}$ is extrapolated from experimental enthalpy data for liquid $\mathrm{UO}_{2}$ to $3500 \mathrm{~K}$ by Leibowitz et al. ${ }^{78}$ The enthalpy data of Hein and Flagella ${ }^{76}$ are in good agreement.

Thermal Conductivity, $\mathrm{K}_{(298)}: \quad 8.4 \mathrm{~W} / \mathrm{m} \cdot \mathrm{K}$

This value recommended by the 1964 IAEA Panel ${ }^{79}$ is based on measurements by Penninckx ${ }^{80}$ on single crystal $\mathrm{UO}_{2}$ from 4 to $300 \mathrm{~K}$. Measurements were also made in the same temperature range by Bethaux et $a l .{ }^{81}$ on sintered polycrystalline $\mathrm{UO}_{2}$.

Norma1. Spertra1 Fmissivity, ${ }^{c}(0.65 \mu \mathrm{m}): 0.07 \pm 0.1$

This value of normal spectral emissivity $0.65 \mu \mathrm{m}$, recommended by Leibowitz et $a 2 .,^{4}$ is from expcriments by Held and W1lder 82 from 450 to $2400 \mathrm{~K}$. It agrees well with the data of Cabannes et al. ${ }^{83}$ but disagrees with the results of Claudson. 84 Claudson's data indicated a decrease in emissivity from 1000 to $2220 \mathrm{~K}$, whereas the more rerent experimento of Hcld and Wilder. show little sensitivity to temperature.

Density, $\rho \frac{(\mathrm{s})}{(298)}: \quad 1.097 \times 10^{4} \mathrm{~kg} / \mathrm{m}^{3}$

The theoretival density of $\mathrm{UO}_{2}$ recommended by Leibowitz et $a \mathrm{l}^{4}$ is from the measurements of Swanson and Fuyat. 85

Density, $\rho(\mathrm{s}): 0.71 \times 10^{3} \mathrm{~kg} / \mathrm{m}^{3}$

This value was calculated by Leibowitz et al. ${ }^{4}$ vi.a the equation:

$\rho\left(\mathrm{kg} / \mathrm{m}^{3}\right)=\left(1.097 \times 10^{4}\right)\left[1+2.04 \times 10^{-5}(\mathrm{~T}-273)+8.7 \times 10^{-y}(\mathrm{~T}-273)^{2}\right]^{-1}$

This equation is based on experiments in the temperature range $298 \mathrm{~K}$ to $3137 \mathrm{~K}$. The results of this equation agree withing $\pm 2 \%$ with the high temperature values reported by Christensen. ${ }^{86}$

Change of Density on Melting, $\left(-\frac{\Delta p}{\rho}\right)_{\text {MP }}: \quad 0.11$

This value is calculated from tabulated density values by Leibowitz et $a l^{4}{ }^{4}$

Volumetric Thermal Expansion Coefficient, $\bar{\alpha} \underset{(298-M P)}{(s)}: 4 \quad 4.5 \times 10^{-5} \mathrm{~K}^{-1}$

This value for the volumetric expansion coefficient is calculated from the linear expansion coefficient obtained from an equation given in Ref. 4.

$$
\alpha(\text { linear })\left(\mathrm{K}^{-1}\right)=6.8 \times 10^{-6}+2.9 \times 10^{-9}(\mathrm{~T}-273)
$$


The results of this equation give good agreement with the data from experiments of Conway et $a Z^{87}$ and that of Christensen ${ }^{86}$ to the melting point.

Volumetric Thermal Expansion Coefficient, $\bar{\alpha} \underset{(\mathrm{MP})}{(\ell)}: \quad .9 \times 10^{-5} \mathrm{~K}^{-1}$

This value was calculated from the mean linear expansion coefficient for liquid $\mathrm{UO}_{2}$ given by Leibowitz et $a{ }^{4}{ }^{4} \mathrm{It}$ is based on the results of thermal expansion data for liquid $\mathrm{UO}_{2}$ by Christensen. 86

Viscosity, $\nu_{(\mathrm{MP})}: \quad(4.30 \pm 0.10) \times 10^{-3} \mathrm{~Pa} \cdot \mathrm{s}$

This is the value tabulated by Leibowitz et $a l^{4}$ It is based on experiments by Woodley. ${ }^{88}$ The experiments of Tsai and Olander $^{89}$ give slightly higher values, but confirm the magnitude of the values of Woodley.

Surface Tension, $\sigma: \quad 0.45 \pm 0.04 \mathrm{~N} / \mathrm{m}$

This value is recommended by Leibowitz et $a{ }^{4}{ }^{4}$ It is an average of three different measurements by Chasanov et $a$ l. 90 
Melting Point: $\quad 3063 \mathrm{~K}$ 1iquidus

$3023 \mathrm{~K}$ solidus

These values were calculated by Leibowitz et $a \tau^{4}{ }^{4}$ They are in good agreement with experimental data of. Lyon and Bailey ${ }^{68}$ and those of Aitken and Evans. ${ }^{91}$

Boiling Point: $3520 \mathrm{~K}$

The boiling point of $3520 \mathrm{~K}$ was calculated by Leibowitz et al. ${ }^{4}$ from vapor pressure data. Although vapor pressure experiments have been performed to $7000 \mathrm{~K}, 92,94-95$ questions exist concerning proper interpretation of the high temperature data obtained by laser-evaporation experiments. Therefore, vapor pressures from calculations of Brpitung, 93 baeod on crsperiluents co $2400 \mathrm{~K}, 94 \div 93$ were used.

Enthalpy, $H_{(M P)}-H_{(298)}: \quad 282.5 \mathrm{~kJ} / \mathrm{mol}$

This value is for the solidus temperature $(3023 \mathrm{~K}$ ) and is from tabulated enthalpy values by Leibowitz et al. ${ }^{4}$ The tabulated valucs of enthalpy differences in the solid range were calculated by an equation derived by Gibby et al. 96 to fit most reliable enthalpy data.97-99 The equation, which is applicable for $\mathrm{T}=298-3000 \mathrm{~K}$ is as follows:

$$
\begin{aligned}
\mathrm{H}_{\mathrm{T}}-\mathrm{H}_{(298)(\mathrm{J} / \mathrm{mol})=} & -1.839 \times 10^{4}+52.47 \mathrm{~T}+3.56 \times 10^{-2} \mathrm{~T}^{2} \\
& =1.63 \times 10^{-5} \mathrm{~T}^{3}+3.20 \times 10^{9} \mathrm{I}^{\prime}
\end{aligned}
$$

Heat of Fusion, $\Delta \mathrm{H}_{\mathrm{m}}: \quad 74.9 \pm 1.2 \mathrm{~kJ} / \mathrm{mol}$

This is the value recommended by teibowitz ot al. ${ }^{4}$ It is the same às that for $\mathrm{UO}_{2}$. Only one measurement of the heat of fusion of the mixed oxide has been made, 100 and this value, $67: 4 \mathrm{~kJ} / \mathrm{mol}$, is within $10 \%$ of the value for $\mathrm{UO}_{2}$. Thus, Leibowitz et al. 100 recommend that the value for $\mathrm{UO}_{2}$ be used until more data are ayailahle.

Enthalpy, $\mathrm{H}_{(\mathrm{BP})}-\mathrm{H}_{(298)}: \quad 425.5 \mathrm{~kJ} / \mathrm{mol}$

The value was obtained from extrapolation of tabulated cnthalpies in Ref. 4. Experimental enthalpy data go to $3000 \mathrm{~K} .100$

Heat of Vaporization, $\Delta \mathrm{H}_{(298)}: \quad 619 \mathrm{~kJ} / \mathrm{mol}$

The heat of vaporization was found from the slope of the log of the vapor pressure vs. inverse temperature curve and applying the Clausius-Claperyon equation. ${ }^{4}$ 
Heat of Vaporization, $\Delta \mathrm{H}_{(\mathrm{BP})}: \cdot 536 \pm 54 \mathrm{~kJ} / \mathrm{mol}$

The heat of vaporization was calculated from vapor pressure data. ${ }^{4}$ Although experimental measurements have been made to $7000 \mathrm{~K}, 92$ questions exist concerning the proper interpretation of the high temperature data obtained by laser-evaporation experiments. Thus, vapor pressure calculations of Breitung ${ }^{93}$ based on experiments to $2400 \mathrm{~K}^{94-95}$ were used.

Heat Capacity, $\mathrm{C}_{(298)}: \cdot 69.6 \mathrm{~J} / \mathrm{K} \cdot \mathrm{mol}$

The value is from tabulated heat capacity values given in Ref. 4. It was calculated from an equation derived by Gibby et al., 96 to fit the most reliable enthalpy data. ${ }^{97-99}$ This equation is:

$$
\mathrm{C}_{\mathrm{p}}(\mathrm{J} / \mathrm{K} \cdot \mathrm{mo} 1)=52.47+7.1 \times 10^{-2} \mathrm{~T}-4.90 \times 10^{-5} \mathrm{~T}^{2}+1.28 \times 10^{-8} \mathrm{~T}^{3}
$$

where $\mathrm{T}$ is in $\mathrm{K}$. The on1y direct measurements of heat capacities were made by Affortit and Marcon.10

Heat Capacity, $\mathrm{C}_{\mathrm{P}}^{(\mathrm{MP})}{ }^{(\mathrm{s})}: \quad 173.3 \mathrm{~J} / \mathrm{K} \cdot \mathrm{mol}$

This value for the heat capacity of the solidus was calculated from Eq. 19 given above for $\mathrm{C}_{\mathrm{p}_{(298)}}$.

Heat Capacity, $\mathrm{C}_{\mathrm{p}}^{(\mathrm{l})} \mathrm{PP}^{(\mathrm{M})}: \quad 136.0 \mathrm{~J} / \mathrm{K} \cdot \mathrm{mol}$

The heat capacity value for liquid $\mathrm{U}_{0.8} \mathrm{Pu}_{0}{ }_{2} \mathrm{O}_{2}$ recommended in Ref. 4 is from enthalpy experiments by Leibowitz et $a$ l. $100^{2}$ Their experimental values agreed with the established values for $\mathrm{UO}_{2}$ within $10 \%$, therefore, the experimenters recommended using the values for molten $\mathrm{UO}_{2}$ until more data are available.

Heat Capacity, $\mathrm{C}_{\mathrm{p}}^{(\mathrm{BP})}: \quad 136.0 \mathrm{~J} / \mathrm{K} \cdot \mathrm{mol}$

No data exist for $\mathrm{U}_{0.8} \mathrm{Pu}_{0.2} \mathrm{O}_{2}$. The value is assumed equal to that for $\mathrm{UO}_{2}$.

Thermal Conductivity, $\mathrm{K}_{(298)}: \quad 6.3 \mathrm{~W} / \mathrm{m} \cdot \mathrm{K}$

The value is from measurements by Seddon.102,103

Normal Sper.t.ral. Emissivity, $\varepsilon_{(0.65 \mu \mathrm{m})}: \quad 0.87 \pm 0.1$

This value is recommended by Leibowitz et $a l^{4}$ for the temperature range from 450 to $2400 \mathrm{~K}$, since no emissivity data for $\mathrm{UO}_{2}-\mathrm{PuO}_{2}$ have been reported. The value is due to emissivity data for $\mathrm{UO}_{2}$ by Held and Wilder. ${ }^{82}$

Density, $\rho(2)(\mathrm{s}): \quad 1.108 \times 10^{4} \mathrm{~kg} / \mathrm{m}^{3}$

This value is from Ref. 4. The density of mixed (U,Pu) oxides has not been directly measured as a function of temperature. It is a function of ${ }^{235} \mathrm{U}$ 
enrichment, $\mathrm{Pu}$ content, $\mathrm{Pu}$ isotopes, and $\mathrm{O} / \mathrm{M} .^{4}$. The equation given \pm nef. 4 to calculate the theoretical density is

$$
\rho\left(\mathrm{kg} / \mathrm{m}^{3}\right)=6.64046 \times 10^{3} \frac{\left[\overline{\mathrm{M}}_{U}+\mathrm{Y}\left(\overline{\mathrm{M}}_{\mathrm{Pu}}-\overline{\mathrm{M}}_{U}\right)+16 \mathrm{X}\right]}{(6.1127-0.534 \mathrm{Y}-0.321 \mathrm{X}+0.229 \mathrm{XY})^{3}}
$$

where

$$
\begin{aligned}
\overline{\mathrm{M}}_{\mathrm{U}} & =\text { average molecular weight of uranium } \\
\overline{\mathrm{M}}_{\mathrm{Pu}} & =\text { average molecular weight of plutonium } \\
\mathrm{X} & =\mathrm{O} / \mathrm{M} \\
\mathrm{Y} & =\mathrm{Pu}_{1} /(\mathrm{I}+\mathrm{Pu})
\end{aligned}
$$

$\mathrm{X}$ and $\mathrm{Y}=$ lattice parameter correlations of Schnizlein ${ }^{103}$

Density, $\stackrel{(\mathrm{s})}{(\mathrm{MP})}: \quad 9.88 \times 10^{3} \mathrm{~kg} / \mathrm{m}^{3}$

The value is from Ref. 4. Leibowitz et al. calculated density as a function of temperature from the equation

$\rho\left(\mathrm{kg} / \mathrm{m}^{3}\right)=1.108 \times 10^{4}\left[1+2.04 \times 10^{-5}(\mathrm{~T}-273)+8.7 \times 10^{-9}(\mathrm{~T}-273)^{2}\right]=1$

where $T$ is in $K$ in the range $273 \leq T \leq 2998$. No density measurements as a function of temperature have been made.

Change in Density on Melting, $\left(-\frac{\Delta \rho}{\rho}\right)_{\text {MP }}: \quad 0.11$

This value is from thermal expansion recommendations of Ref. 4. No data exist for the thermal expansion of (II, $\mathrm{Pu}) \mathrm{C}_{2}$ a above the melting noill. Howcver, since the thermal expansion data for solid (U, $\mathrm{Pu}) \mathrm{O}_{2}$ indicate that the presence of $\mathrm{Pu}$ has little effert, the thermal cxpansion of wullen $\mathrm{UU}_{2}$ from measurements of Christensen ${ }^{86}$ is used for $(\mathrm{U}, \mathrm{Pu}) \mathrm{O}_{2}$. Thus the fractional change

in density at the melting paint for $\mathrm{U}_{U .8} \mathrm{Pu} .2 \mathrm{O}_{2}$ is Laken to be equal to that of $\mathrm{UO}_{2}$. Because (U, $\left.\mathrm{Pu}\right) \mathrm{O}_{2}$ does not have a sharp melting point, the density change is spread over the temperature region between the solidus ( $3023 \mathrm{~K})$ and the liquidus $(3063 \mathrm{~K})$.

Volumetric Thermal Expansion Coefficient, $\bar{\alpha}_{(298-\mathrm{MP})}^{(\mathrm{s})}: \quad 4.5 \times 10^{-5} \mathrm{~K}^{-1}$

Thermal expansion data for $\mathrm{UO}_{2},{ }^{86}, 87 \mathrm{PuO}_{2}, 105,106$ and $\mathrm{U}_{0}, 75 \mathrm{Pu}_{0.25 \mathrm{O}_{2}} 107,110$ indicate that the presence of $\mathrm{Pu}$ has negligible effect on thermal expansion in $\mathrm{UO}_{2}-\mathrm{PuO}_{2}$ solid solutions. Thus, the thermal expansion is taken to be equal to that of $\mathrm{UO}_{2}:^{4}$ 
Volumetric Thermal Expansion Coefficient, $\bar{\alpha}_{(\mathrm{MP})}^{(\ell)}: \quad 9 \times 10^{-5} \mathrm{~K}^{-1}$

There are no data reported for the thermal expansion of liquid $(\mathrm{U}, \mathrm{Pu}) \mathrm{O}_{2}$.

Since the thermal expansion below its melting point is identical to $\mathrm{UO}_{2}$,

Leibowitz et $a \mathrm{l} .{ }^{4}$ recommended using the value for liquid $\mathrm{UO}_{2}$ of Christensen. 86

Viscosity, $_{(\mathrm{MP})}: \quad(4.30 \pm 0.10) \times 10^{-3} \mathrm{~Pa} \cdot \mathrm{s}$

No measurements of the viscosity of $\left(\mathrm{U}_{0.8} \mathrm{Pu}_{0.2}\right) \mathrm{O}_{2}$ have been made. Thus Leibowitz et al. ${ }^{4}$ recommend using the value for $\mathrm{UO}_{2}$ from experiments by Woodley. 88

Surface Tension, $\sigma: \quad 0.45 \pm 0.04 \mathrm{~N} / \mathrm{m}$

The surface tension of $(\mathrm{U}, \mathrm{Pu}) \mathrm{O}_{2}$ has not been determined. Therefore, Leibowitz et al. ${ }^{4}$ recommend using the value for $\mathrm{UO}_{2}$ from three measurements by

Chasanov et al. 90 
Melting Point: $\quad 2773 \pm 35 \mathrm{~K}$

This value, recommended by Rand ${ }^{2}$ is from experiments of Benz and Stone ${ }^{111}$ and those of Henney and Jones. ${ }^{12}$ Wilhelm and Chiottill 3 obtained a higher value of $2898 \pm 25 \mathrm{~K}$.

Enthalpy, $\mathrm{H}_{(\mathrm{MP})}-\mathrm{H}_{(298)}: \quad 155.2 \mathrm{~kJ} / \mathrm{mol}$

This is an estimate made by Schick. ${ }^{114}$ Apparently, no experimental enthalpy data exist.

Heat of Fusion, $\Delta \mathrm{H}_{\mathrm{m}}: \quad 46 \mathrm{~kJ} / \mathrm{mol}$

No experimental data exist. This value was calculated assuming that the entropy of fusion $=n R$, where $n$ equale thc number of alums per molecule ot: the compound.

Heat Capacity, $\mathrm{C}_{\mathrm{P}_{(298)}}: \quad 45.2 \pm 0.4 \mathrm{~J} / \mathrm{K} \cdot \mathrm{mol}$

This value, recommended by Rand, ${ }^{2}$ is from heat capacity measurements from 5 to $300 \mathrm{~K}$ by Danan. 115 The only other measurements have been by Harness et al. from 1.8 to $4.2 \mathrm{~K} .116$

Heat Capacity, $\mathrm{C}_{\mathrm{p}}^{(\mathrm{MP})}: \quad 73.6 \mathrm{~J} / \mathrm{K} \cdot \mathrm{mol}$

This is an estimate made by Schick. 114 Apparently no experimental data exist.

Heat Capacity, $\mathrm{C}_{\mathrm{P}}^{(\mathrm{lP})}{ }_{(\mathrm{MP})}^{(:} \quad 71 \mathrm{~J} / \mathrm{K} \cdot \mathrm{mol}$

No data exist. The value is assumed to be equal to that of UC.

Therma 1 Conductivity, $\mathrm{K}_{(298)^{:}} \quad 12 \mathrm{~W} / \mathrm{m} \cdot \mathrm{K}$

No data on the thermal conductivity of ThC exist. The value is assumed to be equal to that for $\mathrm{Th}_{0.9} \mathrm{U}_{0.1} \mathrm{C}$.

Density, $\rho \frac{(\mathrm{s})}{(298)}: \quad 1.061 \times 10^{4} \mathrm{~kg} / \mathrm{m}^{3}$

The value of the density is that recommended by the Joint Committee on Powder Diffraction Patterns. 17 
Density, $\rho \frac{(\mathrm{s})}{(\mathrm{MP})}: \quad 1.02 \times 10^{4} \mathrm{~kg} / \mathrm{m}^{3}$

This value was calculated by us from thermal expansion coefficients given by Peterson and Curtis in Ref. 3 .

Volumetric Expansion Coefficient, $\bar{\alpha} \underset{(298-M P)}{(s)}: \quad 1.7 \times 10^{-5} \mathrm{~K}^{-1}$

This value is extrapolated from experimental data below $1300 \mathrm{~K}$. The existing data collected in Ref. 3 and the average linear expansion coefficients (when available) for that range are tabulated below.

Table 8. Measurements of the Average Coefficient of Linear Expansion

\begin{tabular}{crll}
\hline $\begin{array}{c}\bar{\alpha} \text { Linear, } \\
10^{-6} / \mathrm{K}\end{array}$ & $\begin{array}{c}\text { Temperature } \\
\text { Range, } \mathrm{K}\end{array}$ & \multicolumn{1}{c}{ Experimenter } & Ref. \\
\hline $6.53 \pm 0.071$ & $291-1114$ & Street and Water & 118 \\
4.6 & $298-1273$ & Chiotti and White & 119 \\
$8.5^{\mathrm{a}}$ & $973-1700$ & Satow & 120 \\
- & $1173-1700$ & Aronson et al. & 121 \\
\hline
\end{tabular}

$\mathrm{a}_{\text {This value is for }} \mathrm{ThC}_{0.96^{\circ}}$. 


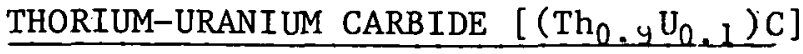

Melting Point: $\quad 2775 \mathrm{~K}$

No data exist. This is the calculated molar average.

Enthalpy, $\mathrm{H}_{(\mathrm{MP})}-\mathrm{H}_{(298)}: \quad 156.9 \mathrm{~kJ} / \mathrm{mol}$

No data exist. This is the calcualted molar average: Note that the value used for ThC in the molar average is an estimate made by Schick.114

Heat of Fusion, $\Delta \mathrm{H}_{\mathrm{m}}: \quad 46 \mathrm{~kJ} / \mathrm{mol}$

No experimental data exist. This value was calculated assuming that the entropy of fusion $=n R$, where $n$ is the number of gram atoms in the compound.

Heat Capacity, $\mathrm{C}_{(298)}: \quad 45.6 \mathrm{~J} / \mathrm{K} \cdot \mathrm{mol}$

No data exist for the mixed monocarbide. This is the calculated molar average.

Heat Capacity, $\mathrm{C}_{\mathrm{P}}^{(\mathrm{s})}: \quad 74.9 \mathrm{~J} / \mathrm{K} \cdot \mathrm{mol}$

No data exist. This is the calculated molar average. Note that the value used for ThC in the molar average is an estimate by Schick. 114

Heat Capac1ty, $\mathrm{c}_{\mathrm{p}_{(\mathrm{MF})}^{(\ell)}}^{(\ell)} \quad 71 \mathrm{~J} / \mathrm{K} \cdot \mathrm{mol}$

This value is assumed equal to that of UC. No data exist for either the mixed monocarbide or lihc.

Thermal Conductivity, $\mathrm{K}_{(298)}: \quad 12 \mathrm{~W} / \mathrm{m} \cdot \mathrm{K}$

This value is from a compilation by Peterson et al. 122 Measurements of the thermal conductivity of $\mathrm{Th}_{0.9 \mathrm{U}_{\mathrm{n}} . \mathrm{C}} \mathrm{C}$ have heen made only at 473 and $1 \mathrm{U} / 3 \mathrm{~K}$ by Griesenauer et al. ${ }^{123}$ The above valuc is an extrapolation from their data at $473 \mathrm{~K}$.

Density, $\rho \frac{(\mathrm{s})}{(298)}: \quad 1.09 \times 10^{4} \mathrm{~kg} / \mathrm{m}^{3}$

This is a molar average calculated by us. No data exist for $\left(T_{0.9} \mathrm{U}_{0.1}\right) \mathrm{C}$.

Density, $\stackrel{(\mathrm{s})}{(\mathrm{MP})}: \quad 1.04 \times 10^{4} \mathrm{~kg} / \mathrm{m}^{3}$

This value was calculated by us from thermal expansion coefficients given by Peterson and Curtis in Ref. 3.

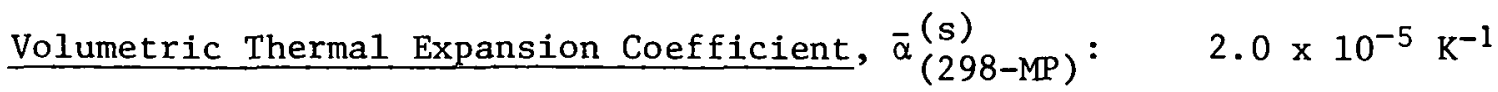

This value is based on measurements made by Griesenauer et al. ${ }^{23}$ below $1300 \mathrm{~K} .^{3}$ 
Melting Point: $\quad 2780 \pm 25 \mathrm{~K}$

This is the value recommended by Johnson et al. 124

Boiling Point: $\quad 4800 \mathrm{~K}$

This value was calculated by Sheth and Leibowitz from estimated vapor pressures.125 Experimental vapor pressure data exist to $2480 \mathrm{~K}$. ${ }^{126}$

\section{Critical Temperature: $\quad 9750 \mathrm{~K}$}

This is an estimate made by Sheth and Leibowitz. ${ }^{125}$

Entha1py, $\mathrm{H}_{(\mathrm{MP})}{ }^{-\mathrm{H}_{(298)}}: \quad 171.33 \mathrm{~kJ} / \mathrm{mol}$

This value is recommended by Storms and Ackermann. 127 The maximum temperature of the experimental data is $2480 \mathrm{~K} .^{126}$

Heat of Fusion, $\Delta \mathrm{H}_{\mathrm{m}}: \quad 46 \mathrm{~kJ} / \mathrm{mol}$

No data exist. This value was calculated assuming the heat of fusion $=\mathrm{nR}$, where $\mathrm{n}$ is the number of atoms per molecule of the compound.

Enthalpy, $H_{(B P)}-\mathrm{H}_{(298)}: \quad 372 \mathrm{~kJ} / \mathrm{mol}$

This value was calculated by Sheth and Leibowitz. ${ }^{25}$ Experimental data go to $2481 \mathrm{~K} .126$

Heat of Vaporization, $\Delta \mathrm{H}_{(298)}: \quad 536 \mathrm{~kJ} / \mathrm{mol}$

This value is estimated by Johnson et al.124 from the total vapor pressure assuming that the vapor is composed solely of UC.

Heat Capacity, $\mathrm{C}_{(298)}:=50.2 \mathrm{~J} / \mathrm{K} \cdot \mathrm{mol}$

This value is recommended by Sheth and Leibowitz. 125 It is from the work of Tetenbaum et al. 126

Heat Capacity, $\mathrm{C}_{\mathrm{p}}^{(\mathrm{s})}$ : $_{(\mathrm{MP})}^{(} \quad 87.4 \mathrm{~J} / \mathrm{K} \cdot \mathrm{mol}$

This is the value recommended by Storms and Ackermann. ${ }^{27}$ Experfmenlal data exist to $2481 \mathrm{~K} .126$

Heat Capacity, $\mathrm{C}_{\mathrm{P}}^{(\mathrm{l})}{ }_{(\mathrm{MP})}^{(\ell)} \quad 71 \mathrm{~J} / \mathrm{K} \cdot \mathrm{mol}$

This value was estimated by Sheth and Leibowitz. ${ }^{125}$ No experimental data exist for the heat capacity of liquid UC. 
Heat Capacity, $\mathrm{C}_{\mathrm{P}}^{(\mathrm{l})}: \quad 87.4 \mathrm{JP} / \mathrm{mol} \cdot \mathrm{K}$

This is an estimated heat capacity calculated by Sheth and Leibowitz. ${ }^{\text {i } 25}$

Thermal Conductivity, $\mathrm{K}_{(298)}: \quad 22 \mathrm{~W} / \mathrm{m} \cdot \mathrm{K}$

This is the value recommended by Johnson et al. ${ }^{124}$ They recommend using equations which were derived to fit the data of Wheeler et al. 128 for thermal conductivity below $2573 \mathrm{~K}$. These formulas are:

$$
\begin{gathered}
\mathrm{K}(\mathrm{W} / \mathrm{m} \cdot \mathrm{K})=0.228 \times 10^{2}-5.01 \times 10^{-3} \mathrm{~T}+3.61 \times 10^{-6 \cdot \mathrm{T}^{2}} \\
(323<\mathrm{T}<973 \mathrm{~K}) \\
\mathrm{K}(\mathrm{W} / \mathrm{m} \cdot \mathrm{K})=19.8+1.48 \times 10^{-3} \mathrm{~T} \\
(973<\mathrm{T}<2573 \mathrm{~K}) .
\end{gathered}
$$

where $\mathrm{K}$ is the thermal conductivity for UC of theoretical density. Correction for low-density material is made using the equation 124

$$
K_{L D}=(1-P) K
$$

where

$$
\begin{aligned}
K & =\text { thelmal, cunductivity of } \mathrm{UC} \text { of } 100 \% \text { theoretical density } \\
K_{L D} & =\text { thermal conductivity of low density material. } \\
P & =\text { the vulume fraction porosity }
\end{aligned}
$$

Thermal Conductivity, $\mathrm{K}_{(\mathrm{MP})}^{(\mathrm{s})}$ : $\quad 24 \mathrm{~W} / \mathrm{m} \cdot \mathrm{K}$

This is an extrapolated value by Lewis and Kerrisk, 129 Fxperimental data go to $2573 \cdot \mathrm{K}^{1 / 8}$ and chow a wide varfacion over the entire temperature range measured.

Thermal Conductivity, $\mathrm{K}_{(\mathrm{MP})}^{(l)}: \quad 20 \mathrm{~W} / \mathrm{m} \cdot \mathrm{K}$

This is an estimate by Sheth and Leibowitz. 125 No experimental data exist on the thermal conductivity of liquid UC.

Norma1 Tota1 Emissivity, $\varepsilon_{\mathrm{T}}: \quad 0.42 \pm 0.02$

This is the value measured by Grossman ${ }^{130}$ between 1250 and $1980 \mathrm{~K}$ and tentatively recommended by Sheth and Leibowitz. 125 It is lower than the emissivities of other refractory carbides and therefore may be too low. No other data exist. 
Normal Spectral Emissivity, $\varepsilon(0.65 \mu \mathrm{m}): 0.539-2 \times 10^{-5} \mathrm{~T}$

This value, tentatively recommended by Sheth and Leibowitz, ${ }^{125}$ was measured by Grossman 130 from $1150 \mathrm{~K}$ to $1890 \mathrm{~K}$. Measurements of the normal spectral emissivity were also made by DeConinck. 131 The value by.Grossman appears to have the same temperature dependence as that of other refractory carbides, but it is lower. Thus it may be too low.

Density, $\rho \frac{(\mathrm{s})}{(298)}: \quad 1.36 \times 10^{4} \mathrm{~kg} / \mathrm{m}^{3}$

This value, recommended by Johnson et al., 124 is from experiments of Mendez-Peñalosa and Taylor. 131 a

Density, $\rho \stackrel{(\mathrm{s})}{(\mathrm{MP})}: \quad 1.23 \times 10^{4} \mathrm{~kg} / \mathrm{m}^{3}$

This value was calculated by us from the thermal expansion coefficients given by Sheth and Leibowitz. 125

Density, $\rho \stackrel{(\ell)}{(\mathrm{BP})}: \quad 8.5 \times 10^{3} \mathrm{~kg} / \mathrm{m}^{3}$

This value is an estimate from an equation derived by Sheth and Leibowitz: ${ }^{125}$

$$
\rho_{L}(\mathrm{UC})\left(\mathrm{kg} / \mathrm{m}^{3}\right)=\frac{1.257 \times 10^{4}}{1+9.98 \times 10^{-5} \mathrm{~T}}
$$

where $T$ (in kelvins) is equal to or greater than the melting point. No experimental data are available.

Volumetric Thermal Expansion Coefficient, $\bar{\alpha}_{(298-\mathrm{MP})}^{(\mathrm{s})}: \quad 3.9 \times 10^{-5} \mathrm{~K}^{-1}$

This value is based on the linear thermal expansion coefficient that was calculated by Sheth and Leibowitz. ${ }^{25}$ They extrapolated the average linear thermal expansion coefficient from the measurements by Andrew ${ }^{132}$ to the melting point. Andrew's measurements range from room temperature to $2273 \mathrm{~K}$.

Volumetric Thermal Expansion Coefficient, ${ }^{-(\ell)}(\mathrm{MP}): \quad 8 \times 10^{-5} \mathrm{~K}^{-1}$

This is an estimate by Sheth and Leibowitz. ${ }^{25}$ There are no experimental data.

Isothermal Compressibility, $\kappa_{\mathrm{T}(298)}: \quad 7.1 \times 10^{-12} \mathrm{~Pa}^{-1}$

This value, recommended by Johnson et al., 124 is due to Kempter. ${ }^{133}$

Viscosity, "(MP): $8 \times 10^{-3} \mathrm{~Pa} \cdot \mathrm{s}$

This is an estimate made by Sheth and Leibowitz. ${ }^{25}$ No data are available. 
URANIUM-PLUTONIUM CARBIDE [( $\left.\left.\mathrm{U}_{0.8} \mathrm{Pu}_{0.2}\right) \mathrm{C}\right]$

Melting Point: $\quad 2780 \mathrm{~K}$ liquidus.

$2548 \mathrm{~K}$ solidus

These are the values of solidus and liquidus from experiments of Reavis, Johnson, and Leary. ${ }^{135}$ Their results have been recommended by Fee and Johnson. 134

Boiling Point: $\quad 4560 \mathrm{~K}$

This value was calculated by Sheth and Leibowitz ${ }^{125}$ from calculated total vapor pressures as a function of temperature. No vapor pressure measurement.s have been made.

Crit1cal lemperature: $\quad 9653 \mathrm{~K}$

This is an estimate made by Sheth and Leihnwitz. ${ }^{125}$

Enthalpy, $\mathrm{H}_{(\mathrm{MP})}-\mathrm{H}_{(298)}: \quad 152.3 \mathrm{~kJ} / \mathrm{mol}$

This value is based on enthalpy measurements by D. F. Fischer from 1039 to $2421 \mathrm{~K}, 136$ who derived an equation to $\mathrm{fit}$ his experimental data and the estimated enthalpy values 126 for lower temperatures. The equation is as follows:

$$
\begin{aligned}
\mathrm{H}_{\mathrm{T}}-\mathrm{H}_{(298)=} & -12.4866 \times 10^{3}+32.5225 \mathrm{~T}+37.2021 \times 10^{-3} \mathrm{l}^{2} \\
& -20.8151 \times 10^{-6} \mathrm{~T}^{3}+13.8487 \times 10^{-10} \mathrm{~T}^{4}
\end{aligned}
$$

where $H$ is in joules per mole and $T$ is in kelvins.

Heat of Fusion, $\Delta \mathrm{H}_{\mathrm{m}}: \quad 45.6 \mathrm{~kJ} / \mathrm{mol}$

This was calculated by mole average from the calculated heats of fusion of UC $(48.87 \mathrm{~kJ} / \mathrm{mol})$ and of $\mathrm{PuC}_{0} .88(37.97 \mathrm{~kJ} / \mathrm{mol}) .^{125}$

Enthalpy, $\mathrm{H}_{(\mathrm{BP})}-\mathrm{H}_{(298)}: \quad 351.5 \mathrm{~kJ} / \mathrm{mol}$

This value was calculated by Sheth and Leibowitz.125 Experimental enthalpy data exist to $2421 \mathrm{~K} .136$.

Heat of Vaporization, $\Delta \mathrm{H}_{(298)}: \quad 536 \mathrm{~kJ} / \mathrm{mol}$

This value was calculated by Sheth and Lelbowitz.125 No data are available.

Heat Capacity, $\mathrm{C}_{(298)}: \quad 46.4 \mathrm{~J} / \mathrm{K} \cdot \mathrm{mol}$

This is the value for heat capacity recommended by Tetenbaum et al. 126 
Heat Capacity, $\mathrm{C}_{\mathrm{p}}^{(\mathrm{s})}: \quad 106.8 \mathrm{~J} / \mathrm{K} \cdot \mathrm{mol}$

This value is an extrapolated value based on the enthalpy data of D. F. Fischer measured at 1039 to $2421 \mathrm{~K} .^{136}$

Heat Capacity, $\mathrm{C}_{\mathrm{P}}^{(\mathrm{l})}: \quad 71 \mathrm{~J} / \mathrm{K} \cdot \mathrm{mol}$

This is an estimate made by Sheth and Leibowitz. ${ }^{125}$ No experimental data are available.

Heat Capacity, $\mathrm{C}_{\mathrm{P}}^{(\mathrm{l})}: \quad 84.9 \mathrm{~J} / \mathrm{K} \cdot \mathrm{mol}$

This is an estimate made by Sheth and Leibowitz. ${ }^{25}$ No data are available.

Thermal Conductivity, $\mathrm{K}_{(298)}: \quad 17 \mathrm{~W} / \mathrm{m} \cdot \mathrm{K}$

This is the value recommended by Lewis and Kerrisk. ${ }^{129}$

Thermal Conductivity, $\mathrm{K}_{(\mathrm{MP})}^{(\mathrm{s})}$ : $23 \mathrm{~W} / \mathrm{m} \cdot \mathrm{K}$

This value was extrapolated by Lewis and Kerrisk ${ }^{129}$ From available experimental data to $573 \mathrm{~K}$. Owing to inconsistencies in these data and the fact that some temperatures are not covered by experiments, a complete understanding of variations in thermal conductivity is lacking.

Thermal Conductivity, $\mathrm{K}_{(\mathrm{MP})}^{(l)}: \quad 20 \mathrm{~W} / \mathrm{m} \cdot \mathrm{K}$

This is an estimate by Sheth and Leibowitz. ${ }^{125}$ No experimental data exist on the thermal conductivity of liquid $\left(\mathrm{U}_{0.8} \mathrm{Pu}_{0.2}\right) \mathrm{C}$.

Density, $\rho \frac{(\mathrm{s})}{(298)}: \quad 1.35 \times 1.0^{4} \mathrm{~kg} / \mathrm{m}^{3}$

This value is recommended by Johnson et al. 124 It is based on two measurements by Andrew and Latimer ${ }^{132}$ which are tabulated in Table 9.

Table 9. Density Measurements of Andrew and Latimer ${ }^{132}$

\begin{tabular}{|c|c|c|c|c|}
\hline \multicolumn{2}{|c|}{ U Composition } & \multicolumn{2}{|c|}{ Pu Composition } & \multirow[b]{2}{*}{$\begin{array}{c}\text { Measured Density, } \\
\mathrm{kg} / \mathrm{m}^{3}\left(\mathrm{x} 10^{3}\right)\end{array}$} \\
\hline $\begin{array}{c}23{ }^{23} \mathrm{U}, \\
\%\end{array}$ & $\begin{array}{c}{ }^{230} \mathrm{U} \\
\%\end{array}$ & $\begin{array}{c}2{ }^{39} \mathrm{Pu}, \\
\%\end{array}$ & $\begin{array}{c}{ }^{240} \mathrm{Pu}, \\
\%\end{array}$ & \\
\hline 9.7 & $\begin{array}{c}99.3 \\
7\end{array}$ & $\begin{array}{l}88-94 \\
88-94\end{array}$ & $\begin{array}{l}6-12 \\
6-12\end{array}$ & $\begin{array}{l}13.58 \pm 0.01 \\
13.46 \pm 0.01\end{array}$ \\
\hline
\end{tabular}


Density, $\stackrel{(\mathrm{s})}{\rho(\mathrm{MP})}: \quad 1.23 \times 10^{4} \mathrm{~kg} / \mathrm{m}^{3}$

This value was calculated by us based on thermal expansion coefficients given by Sheth and Leibowitz. ${ }^{125}$

Density, $\rho \stackrel{(\ell)}{(B P)}: \quad 8.6 \times 10^{3} \mathrm{~kg} / \mathrm{m}^{3}$

This value is an estimate from an equation derived by Sheth and Leibowitz: ${ }^{125}$

$$
\rho_{\mathrm{L}}=\frac{12.39 \times 10^{3}}{1+9.84 \times 10^{-5} \mathrm{~T}}\left(\mathrm{~kg} / \mathrm{m}^{3}\right)
$$

where $T(i, i \mathrm{k})$ 1o cqual to us greacer than the melting point. No experimental data are available.

Volumetric Thermal Expansion Coefficient, $\bar{\alpha}_{(298-\mathrm{MP})}^{(\mathrm{s})}: \quad 3.4 \times 10^{-5} \mathrm{~K}^{-1}$

This is an estimate made by Sheth and Leibowitz ${ }^{125}$ based on the low-temperature data given by Andrew and Latimer. 132

Volumetric Therma1 Expansion Coefficient, $\underset{(\mathrm{MP})}{-(\ell)}: \quad 6.8 \times 10^{-5} \mathrm{~K}^{-1}$

This is an estimate by Sheth and Leibowitz.125 No experimental data exist.

Viocosity, $v_{(\mathrm{MP})}: \quad 7 \times 10^{-3} \mathrm{~Pa} \cdot \mathrm{s}$

This is an est1mate made by Sheth and Leibowilz. ${ }^{125}$ № data are available. 
THORIUM DICARBIDE $\left(\mathrm{ThC}_{2}\right)$

Melting Point: $\quad 2 \dot{y} 13 \pm 30 \mathrm{~K}$

ihis is the value recommended by Fand. ${ }^{2}$ It is close to the mean of two experimental measurements, namely, that of Benz and Stone ${ }^{111}$ who found a melting point of $2883 \pm 35 \mathrm{~K}$, and that of Wilhelm and Chiotti ${ }^{1}{ }^{3}$ who measured the melting point as $2938 \pm 25 \mathrm{~K}$.

Boiling Point: $\quad 5400 \mathrm{~K}$

This is an extrapolated value. ${ }^{3}$

Enthalpy, $\mathrm{H}_{(\mathrm{MP})}-\mathrm{H}_{(298)}: \quad 218 \mathrm{~kJ} / \mathrm{mol}$

This value was estimated from data in Ref. 3 (p. 96, Table 19). However, that table is also based on estimates. The experimental data on enthalpy, which extend to about $1200 \mathrm{~K}$, are inconsistent.

Heat of Fusion, $\Delta \mathrm{H}_{\mathrm{m}}: \quad 71 \mathrm{~kJ} / \mathrm{mol}$

No experimental data are available. This value was calculated by assuming that the heat of fusion $=n R$, where $n$ is the number of atoms per molecule of the compound.

Heat of Vaporization, $\Delta \mathrm{H}_{\mathrm{v}}: \quad 690 \mathrm{~kJ} / \mathrm{mol}$

There is much controversy regarding the available vapor pressure data. ${ }^{3}$ Experimental data of Lonsdale and Graves ${ }^{137}$ from 2278 to $2897 \mathrm{~K}$ are uncertain because of possible oxygen contamination in their $\mathrm{ThC}_{2}$ source. Measurements by Jackson et al. 13 from 2371 to $2642 \mathrm{~K}$ give pressures lower by a factor of five. However, according to Storms, 139 the measurements of Kent ${ }^{140}$ are close to the values of Lonsdale and Graves.

Heat Capacity, $C_{p_{(298)}}:=56.69 \pm 0.59 \mathrm{~J} / \mathrm{K} \cdot \mathrm{mol}$

This value, recommended by Peterson and Curtis, ${ }^{3}$ is from experiments by Westrum et al. 141 from 5 to $350 \mathrm{~K}$. Measurements by Takahashi et al.14\% for a near-stoichiometric specimen give $56.86 \mathrm{~J} / \mathrm{K} \cdot \mathrm{mol}$. An equation given by Rand $^{2}$ for the temperature range $298-1700 \mathrm{~K}$ gives $58.95 \mathrm{~J} / \mathrm{K} \cdot \mathrm{mol}$ at $298 \mathrm{~K}$. The equation is

$$
\mathrm{C}_{\mathrm{P}}(\alpha \text { phase })(\mathrm{J} / \mathrm{K} \cdot \mathrm{mol})=65.69+1.209 \times 10^{-2} \mathrm{~T}-9.25 \times 10^{5} \mathrm{~T}^{2}
$$

Heat Capacity, $\mathrm{C}_{\mathrm{P}}^{(\mathrm{s})}:=83.6 \mathrm{~J} / \mathrm{K} \cdot \mathrm{mol}$

I'his value recommended by Rand $^{2}$ is an estimate by Holley and Storms. 143 No experimental data exist. 
Density, $\rho \frac{(\mathrm{s})}{(298)}: \quad 9.6 \times 10^{3} \mathrm{~kg} / \mathrm{m}^{3}$

This is the value recommended by the Joint Committee on Powder Diffraction Patterns. 144

Density, $\stackrel{(\mathrm{s})}{\rho(\mathrm{MP})}: \quad 9.0 \times 10^{3} \mathrm{~kg} / \mathrm{m}^{3}$

This value was calculated by us from the thermal expansion coefficients given by Peterson and Curtis in Ref. 3.

Volumetric Thermal Expansion Coefficient, ${ }^{-(s)} \underset{(298-M P)}{(s)}: \quad 7.8 \times 10^{-5} \mathrm{k}^{-1}$

'l'his value, rernmmended by Pctcrson aul Curlis, ${ }^{3}$ is from measurements of Langer et $a z .145$ to $2100 \mathrm{~K}$. Measurements of the expansion of graphilesaturated $\mathrm{ThC}_{2}$ were made by Cook 146 up to $1300 \mathrm{~K}$.

Temperature of Phase Transitions: $\quad \alpha \rightarrow \beta, 1427 \mathrm{~K}$

$$
\beta \rightarrow \gamma, 1490 \mathrm{~K}
$$

These values are recommended values of Rand $^{2}$ based on eight experiments. The experimental values for. the carbon-rich samples are tabulated in Table 10.

Table 10. Temperatures of the Phase Transitions of $\mathrm{ThC}_{2}$

\begin{tabular}{ccll}
\hline$T(\alpha+\beta), K$ & $T(\beta \rightarrow \gamma), K$ & \multicolumn{1}{c}{ Experimenter } & Ref. \\
\hline 1713 & 1768 & Benz and Etone & 111 \\
$1703 \pm 10$ & $1773 \pm 25$ & Cook & 146 \\
$1643 \pm 15$ & $1743 \pm 15$ & Chiotti and White & 119 \\
1683 & 1749 & Dolton et al. & 147 \\
$1683 \pm 20$ & $1773 \pm 20$ & Henney and Jones & 112 \\
$1688 \pm 10$ & 1773 & Hill and Cavin & 148 \\
1703 & 1763 & Krikorian and Wallace & 149 \\
$1700 \pm 21$ & $1754 \pm 28$ & Tanger et $\alpha Z$. & 145 \\
\hline
\end{tabular}




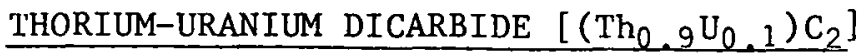

Melting Point: $2900 \mathrm{~K}$

This value is a calculated molar average. The phase diagram given in Fig. 24 , page 101 , of Ref. 3 indicates an incorrect melting point for $\mathrm{ThC}_{2}$. We assumed no minimum in the melting diagram (as stated on page 102 of the report) and used a molar average.

Enthalpy, $\mathrm{H}_{(\mathrm{MP})}-\mathrm{H}_{(298)}: .222 \mathrm{~kJ} / \mathrm{mol}$

This value is a calculated molar average. No data exist.

Heat of Fusion, $\Delta \mathrm{H}_{\mathrm{m}}: \quad 67 \mathrm{~kJ} / \mathrm{mol}$

This value was calculated assuming that the heat of fusion $=n R$, where $n$ is the number of gram atoms in the compound. No experimental data exist.

Heat Capacity, $\mathrm{C}_{(298)}:: 57.3 \mathrm{~J} / \mathrm{K} \mathrm{mol}$

This is a calculated molar average. No experimental data exist.

Heat Capacity, $\mathrm{C}_{\mathrm{p}}^{(\mathrm{s})}:=87.9 \mathrm{~J} / \mathrm{K} \cdot \mathrm{mol}$

This is a calculated molar average. No experimental data exist.

Thermal Conductivity, $\mathrm{K}_{(298)}: \quad 18.8 \mathrm{~W} / \mathrm{m} \cdot \mathrm{K}$

This value was extrapolated from tabulated experimental data in Ref. 3 . Measurements have been made from 473 to $1223 \mathrm{~K}$ by Griesenauer et al.123

Density, $\frac{(\mathrm{s})}{(298)}: \quad 9.8 \times 10^{3} \mathrm{~kg} / \mathrm{m}^{3}$

This value is a molar average. Apparently no experimental data exist.

Density, $\rho(\mathrm{s}): \quad 9.1 \times 10^{3} \mathrm{~kg} / \mathrm{m}^{3}$

This value was calculated using the coefficients of thermal expansion given by Peterson and Curtis in Ref. 3.

Volumetric Thermal Expansion Coefficient, $\bar{\alpha}_{(298-M P)}^{(s)}: \quad 2.7 \times 10^{-5} \mathrm{~K}^{-1}$

This value is based on tabulated values ${ }^{3}$ of linear thermal expansion coefficients measured by Cook to $1300 \mathrm{~K} .146$ 


\section{URANIUM DICARBIDE. $\left(\mathrm{UC}_{2}\right)$}

Melting Point: $2780 \mathrm{~K}$

This is the melting point recommended by Fee and Johnson. 134

Enthalpy, $\mathrm{H}_{(\mathrm{MP})}-\mathrm{H}_{(298)}: \quad 256.0 \mathrm{~kJ} / \mathrm{mol}$

This value is recommended by Storms and Ackermann ${ }^{127}$, based on experiments to $1600 \mathrm{~K}$. The maximum temperature of $\mathrm{UC}_{2}$ experimental data is $2500 \mathrm{~K}$. However, these data are uncertain owing to composition changes during the experiment. $\mathrm{UC}_{2}$ enthalpy data are probably reliable to $1600 \mathrm{~K}$.

Heat of Fusion, $\Delta \mathrm{H}_{\mathrm{m}}: \quad 67 \mathrm{~kJ} / \mathrm{mol}$

This value was calculated assuming the heat of fusion $=n R$, where $n$ is the number of gram atoms in the compound.

Heat Capacity, $\mathrm{C}_{\mathrm{P}_{(298)}}: \quad 60.7 \mathrm{~J} / \mathrm{K} \cdot \mathrm{mo1}$

This is the recommended value by the IAEA Panel. 127

Heat Capacity, $\mathrm{C}_{\mathrm{P}}^{(\mathrm{s})}: \quad 123.0 \mathrm{JP} / \mathrm{K} \cdot \mathrm{mo1}$

This value is recommended by Storms and Ackermann ${ }^{127}$ based on experiments to $1600 \mathrm{~K}$. The maximum temperature of experimental data is $2500 \mathrm{~K}$. However, these data are uncertain due to composition changes during the experiment. $\mathrm{UC}_{2}$ enthalpy and heat capacity data are probably reliahle to $1600 \mathrm{~K}$.

Density, $\rho \frac{(\mathrm{s})}{(298)}: \quad 1.17 \times 10^{4} \mathrm{~kg} / \mathrm{m}^{3}$

This value was calculated from the lattice parameters ${ }^{150}$ for $\mathrm{UC}_{2}$. No density measurements exist.

Density. $\frac{(\mathrm{s})}{(\mathrm{MP})}: \quad 1,06 \mathrm{k.g} / \mathrm{m}^{3}$

This value was calculated by us using the thermal expansion coefficients given by Peterson and Curtis in Ref. 3 .

Volumetric Thermal Expansion Coefficient, ${ }_{(298-M P)}^{-(s)}: \vdots 4.0 \times 10^{-5} \mathrm{~K}^{-1}$

This value is from tabulated values ${ }^{3}$ of linear thermal expansion coefficients measured by Cook to $1300 \mathrm{~K} .{ }^{146}$ 


\section{APPENDIX}

To facilitate the comparison of properties of thorium and uranium systems, plots of some properties are included here. Figure 1 plots the vapor pressure of thorium and uranium metals as a function of temperature. Figures 2 to 4 , respectively, show the heat capacities, enthalpies, and vapor pressures of both $\mathrm{ThO}_{2}$ and $\mathrm{UO}_{2}$ as a function of temperature. Figure 5 is a plot of pressure vs. enthalpy for $\mathrm{ThO}_{2}$ and $\mathrm{UO}_{2}$. On each curve, the highest temperature at which experimental data exist is indicated by an arrow pointing to that temperature. 


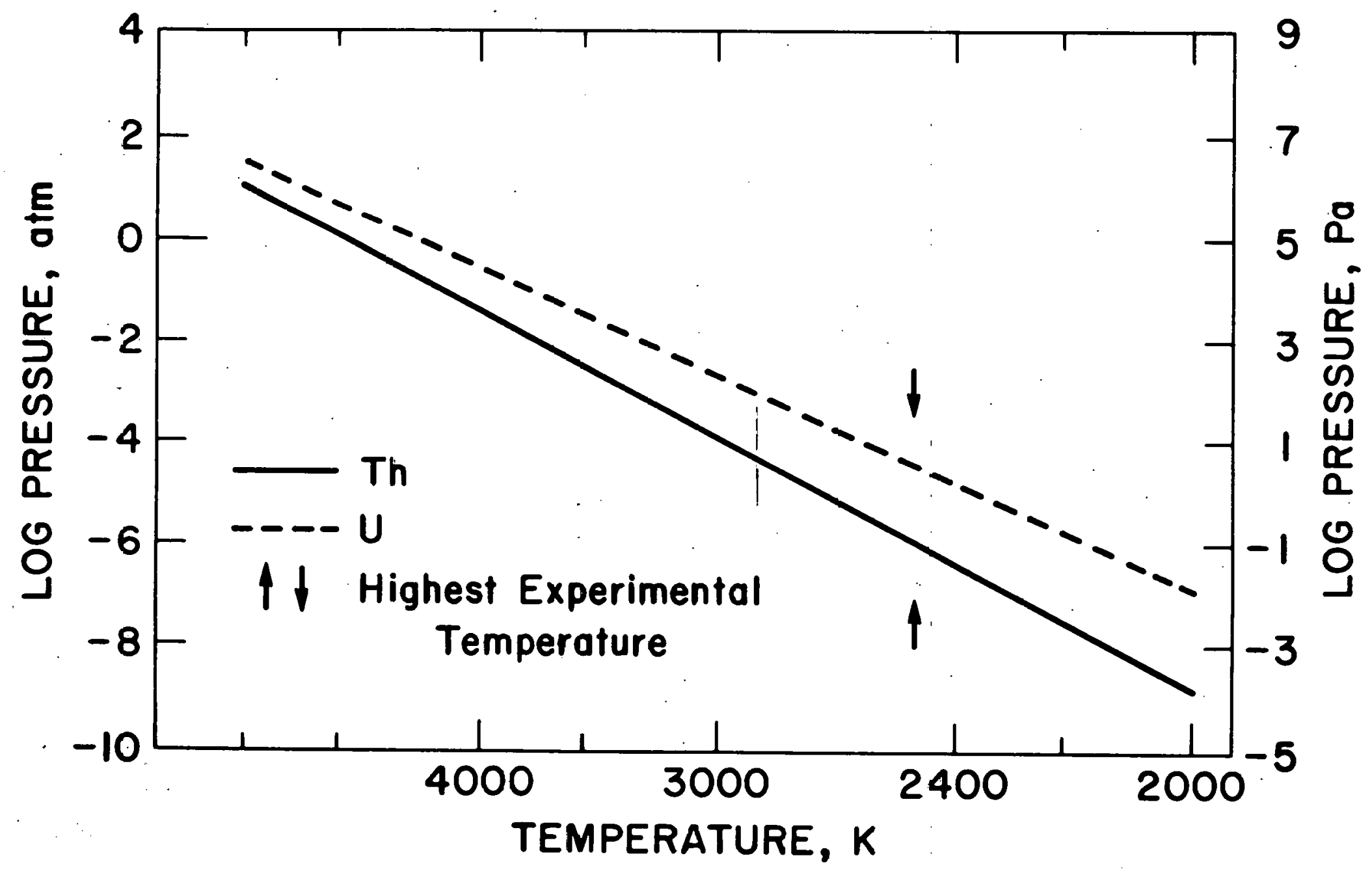

Fig. 1. Vapor Pressure vs. Temperature for Thorium and Uranium 


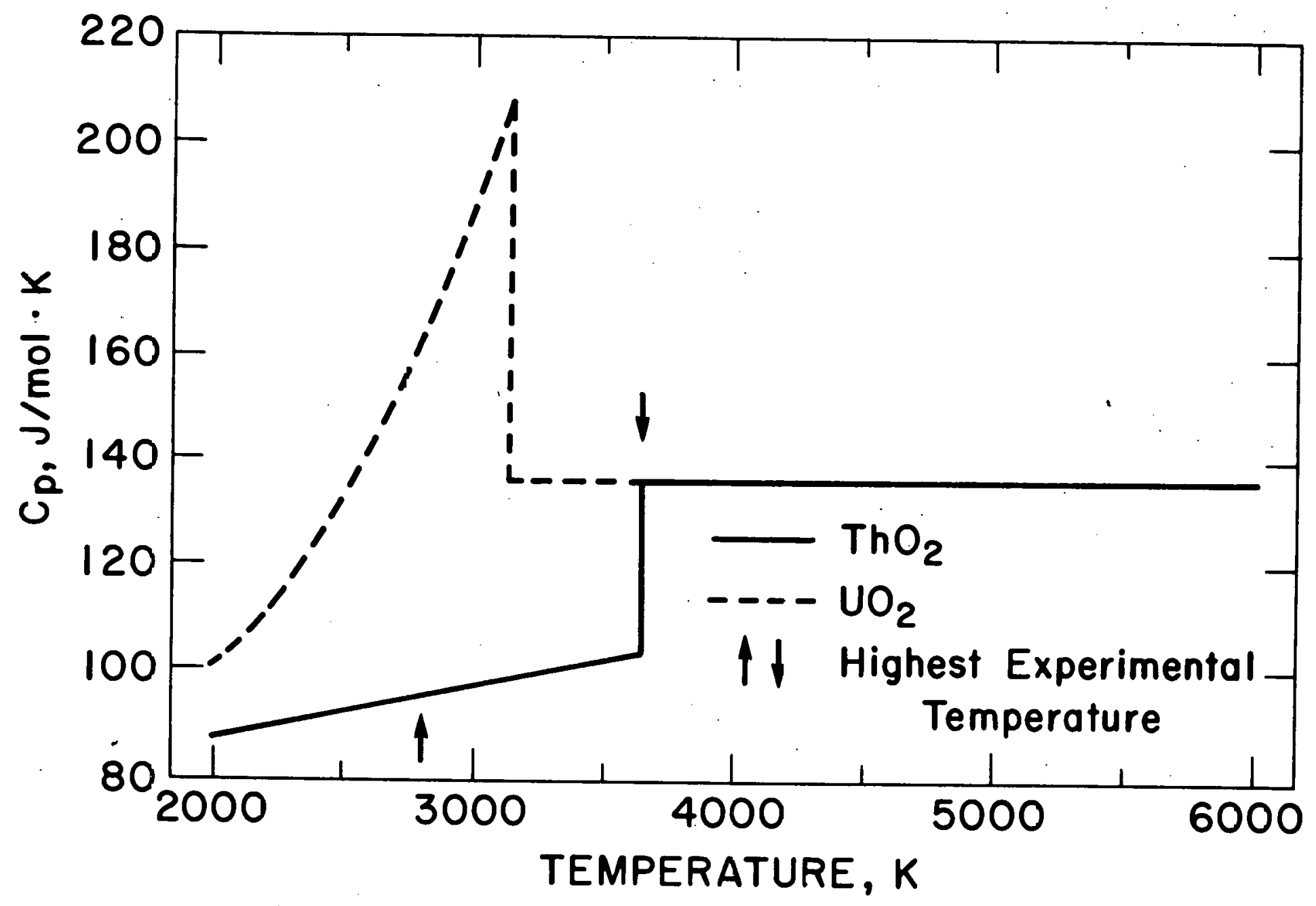

Fig. 2. Heat Capacity vs. Temperature for $\mathrm{ThO}_{2}$ and $\mathrm{UO}_{2}$ 


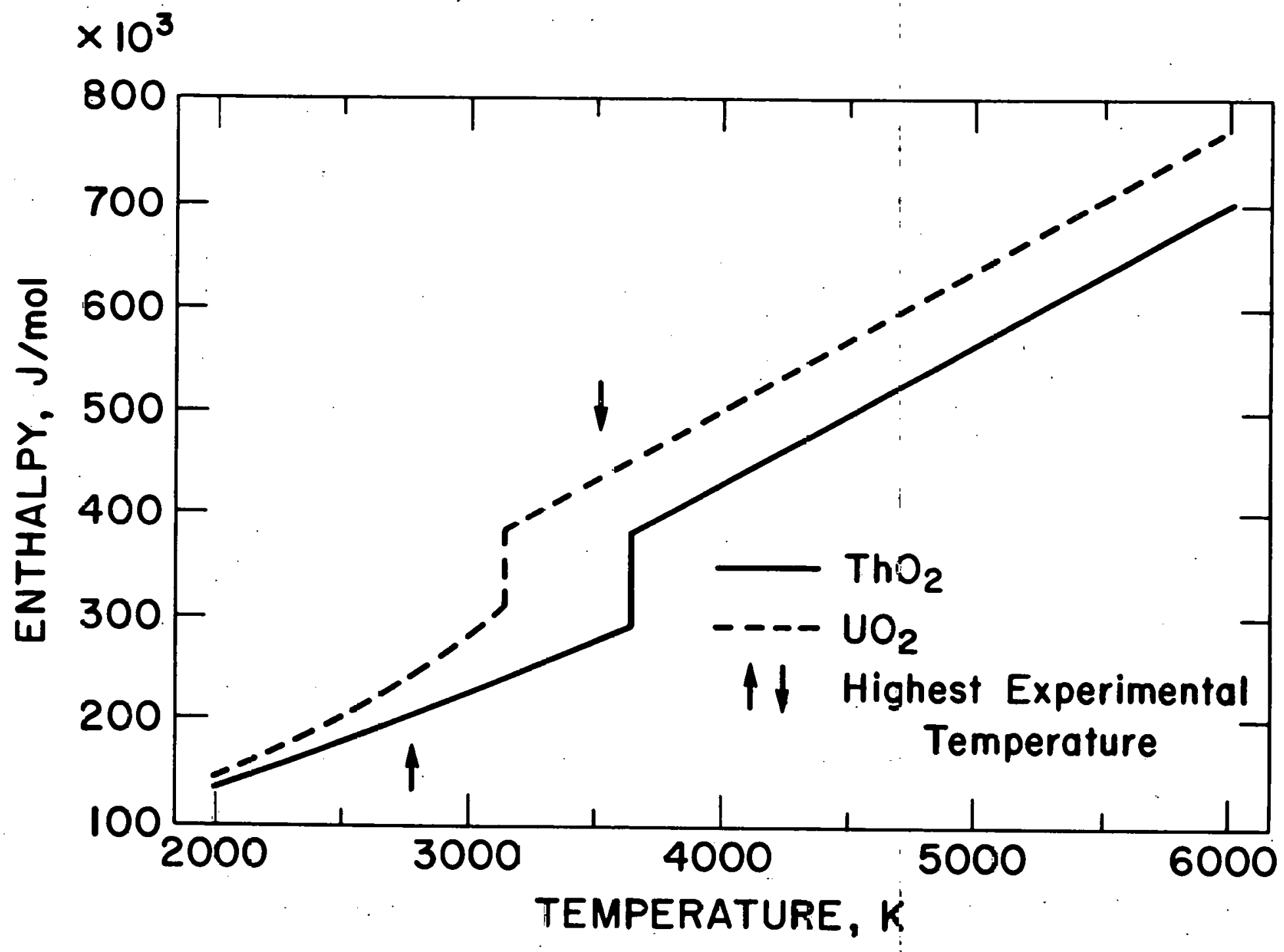

Fig. 3. Enthalpy vs. Iemperature for $\mathrm{ThO}_{2}$ and $\mathrm{UO}_{2}$ 


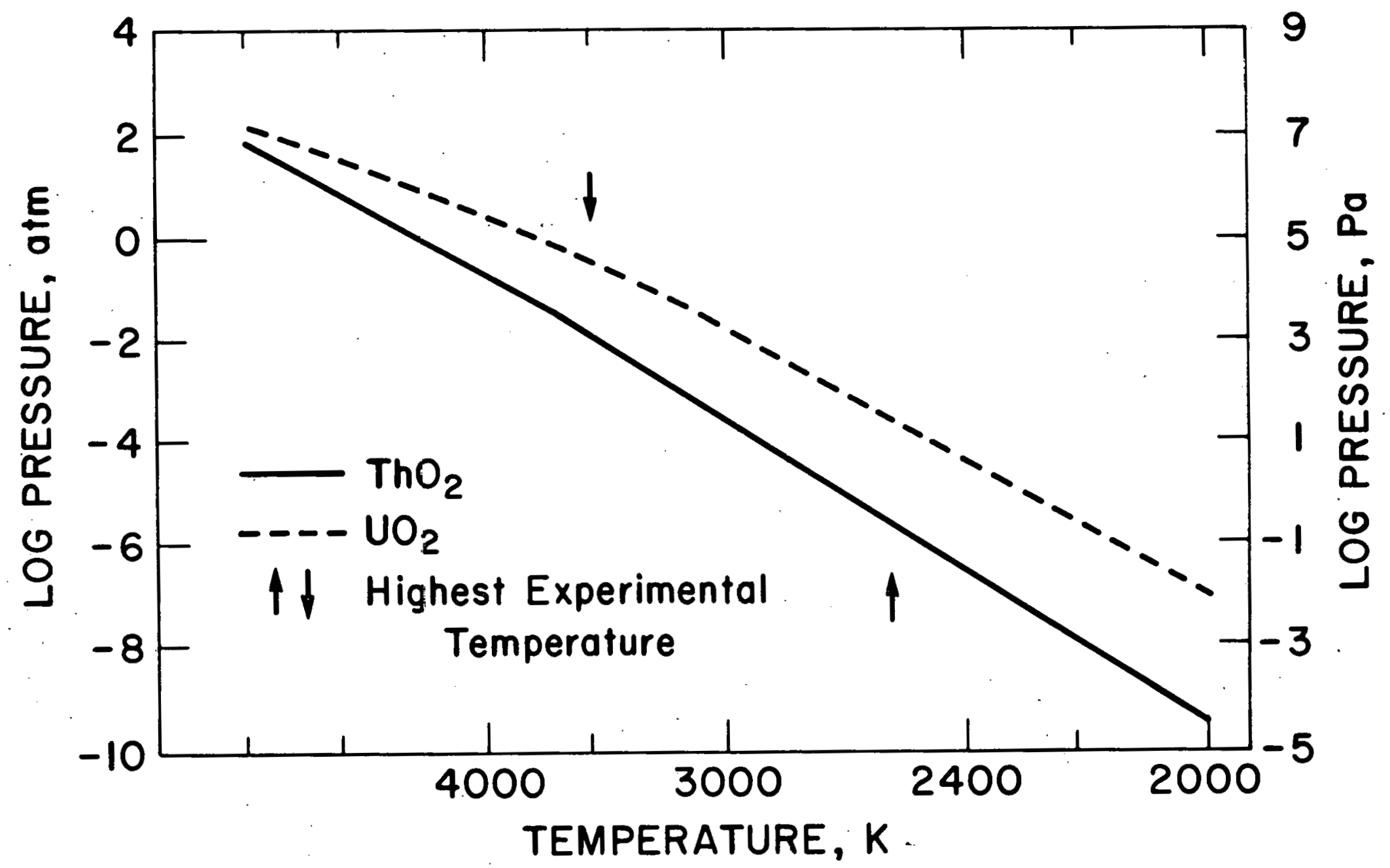




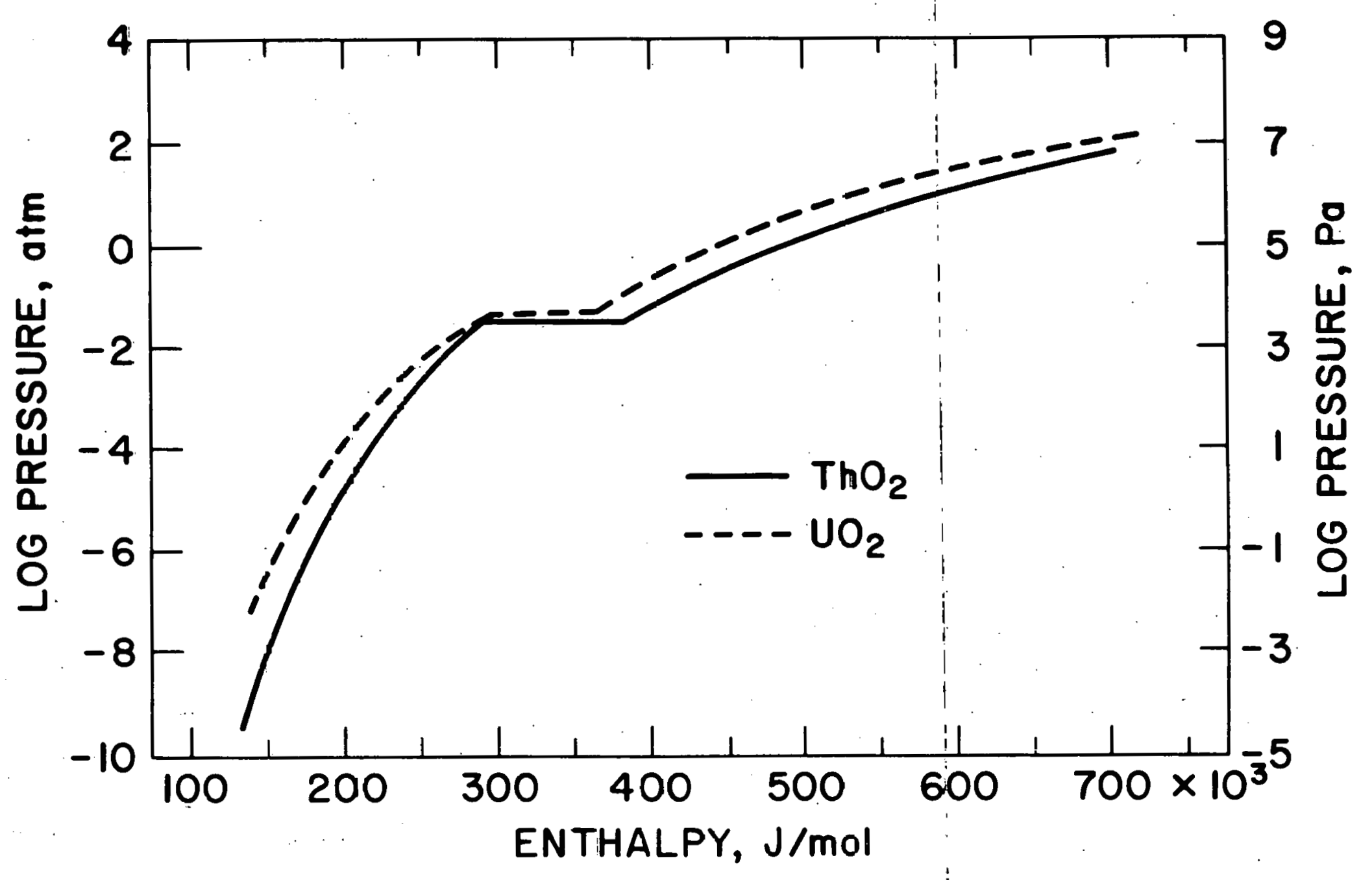

Fig. 5. Pressure vs. Enthalpy for $\mathrm{ThO}_{2}$ and $\mathrm{UO}_{2}$ 


\section{REFERENCES}

1. F. L. Oetting, M. H. Rand, and R. J. Ackermann, The Chemical Thermodynamics of Actinide Elements and Compounds. Part 1. The Actinide Elements, IAEA, Vienna (1976).

2. 0. Kubaschewski, Ed., Thorium: Physico-Chemical Properties of its Compounds and AZloys, IAEA, Vienna (1975).

3. S. Peterson and C. E. Curtis, Thorium Ceramies Data Manual, ORNL-4503, Vol. I (Sept 1970), Vol, III (Apr 1971).

4. L. Leibowitz et al., Properties for LMFBR Safety Analysis, Argonne National Laboratory Report, ANL-CEN-RSD-76-1 (Apr 1976).

5. R. J. Ackermann and E. G. Rauh, High Temp. Sci. 4, 272 (1972).

6. R. Benz, C. G. Hoffman, and G. N. Rupert, J. Amer. Chem. Soc. 89, 191 (1967).

7. P. Chiotti and K. J. Gill, Trans. Met. Soc. AIME 221, 573 (1961).

8. D. T. Eash and O. N. Carlson, Irans. Amer. Soc. Met. 32, 1097 (1960).

9. F. W. Korbitz, Thesis, Iowa State University of Science and Technology as cited in Ref. 1.

10. L. S. Levinson, J. Nuc1. Mater. 19, 50 (1966).

11. R. J. Ackermann and E. G. Rauh, J. Chem. Thermodyn. 4, 521 (1972).

12. M. Griffel and R. E. Skochdapole, J. Amer. Chem. Soc. 75, 5250 (1953).

13. Y. S. Touloukian, R. W. Powe1, C. Y. Ho, and P. G. Klemens, Thermal Conductivity Nonmetallic Solids, Thermophysical Properties of Matter, Vol. 2, New York (1970).

13a. L. L. Marsh, Jr., and J. R. Keeler, USAEC Report BMI-76, 1-46 (1951).

13b. 0. N. Carlson, P. Chiotti, G. Murphy, D. Peterson, B. A. Rogers, J. F. Smith, M. Smutz, M. Voss, and H. A. Wilhelm, Proc. Int. Conf. Peaceful Uses of Atomic Energy 9, 74106 (1955).

14. W. J. Jalles and M. E. Strawman1s, Acta Crystallogr. 9, 376 (1956).

15. R. W. Wyckoff, Crystal Structures, 2nd Ed., Interscience Fubl., New York (1963-1968).

15a. J. F. Smith, Physical Constants, Crystal Structure, and Thermodynamic Properties, in The Metal Thorium, American Society of Metals, pp. 133-147 (1958).

16. P. Chiotti, J. Electrochem. Soc. 101, 567 (1954). 
17. P. Chiotti and K. J. Gi11, Trans. Met. Soc. AIME 221, 573 (1961).

18. O. D. McMasters and W. L. Larsen, J. Less-Common Metals 3, 312 (1961).

19. G. H. Bannister and J. R. Thompson, J. Nucl. Mater. 12, 16 (1954).

20. S. Takeuchi, T. Houma, T. Satow, and T. Hirei, Trans. Jap. Inst. Met. 7, 59 (1966).

21. W. B. Wilson, A. E. Austin, and C. M. Schwartz, Trans. Met. Soc. AIME 212,52 (1958).

22. R. J. Ackermann and E. G. Rauh, J. Phys. Chem. 73, 769 (1969).

23. B. J. Blumenthal, J. Nuc1. Mater. 2, 23 (1960).

24. R. J. Buzzard, R. B. Liss, and D. D. Fickle, J. Res. Nat. Bur. Stand. $50,209(1953)$.

25. M. C. Udy and F. W. Boulger, J. Met. 6, 207 (1954).

26. A. I. Dahl and H. E. Cleaves, J. Res. Nat. Bur. Stand. 43, 513 (1949).

27. G. E. Moore and K. K. Kelley, J. Amer. Chem. Soc. 69, 2105 (1947).

28. D. C. Ginnings and R. J. Corruccini, J. Res. Nat. Bur. Stand. 39, 309 (1947).

29. J. M. North, UKALA Kesearch Group, Harwell Atomic Energy Research Establishment, Report M/R 1016.

30. H. Savage and R. D. Seibel, Argonne National Laboratory Report ANL-6702 (1963).

31. E. A. Mit'kina, At. Ehnerg. 7, 163 (1959).

32. L. S. Levinson, J. Chem. Phys. 40, 3584 (1964).

33. H. P. Stephens, High. Temp. Sci. 6, 156 (1974).

34. E. G. Rauh and R. J. Thorn, J. Chem. Phys. 22, 14 (1954).

35. G. DeMaria, R. P. Burns, J. Drowart, and M. B. Inghram. J. Chem. Phys. 32, 1373 (1960).

36. C. B. Alcock and P. Grieveson, J. Inst. Met. 90, 304 (1961-62).

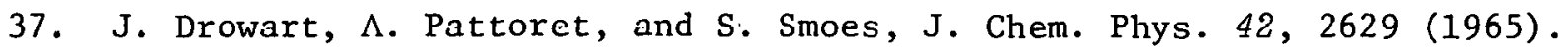

38. J. M. Leitnaker and T. G. Godfrey, J. Nuc1. Mater. 21, 175 (1967).

39. E. K. Storms, The Refractory Carbides, Academic Press, New York, p. 202 (1967): 
40. A. Pattoret, J. Drowart, and S. Smoes, Thermodynomics of Nuclear Materials, Proc. IAEA Symp., 1967, IAEA, Vienna, p. 613 (1968).

41. A. Pattoret, J. Drowart, and S. Smoes, Trans. Faraday Soc. 65, 98 (1969).

42. R. J. Ackermann, E. G. Rauh, and M. S. Chandrasekhariah, J. Phys. Chem. 73, 762 (1969).

43. R. J. Ackermann and E. G. Rauh, High Temp. Sci. 4, 496 (1972).

44. F. L. Oetting and J. M. Leitnaker, J. Chem. Thermodyn. 4, 199 (1972).

45. H. E. Flowtow and H. R. Lohr, J. Phys. Chem. 64, 904 (1960).

46. H. E. Flowtow and D. W. Osborne, Phys. Rev. 151, 564 (1966).

46a. H. M. Rosenberg, Phil. Trans. Roy. Soc., London, A247, 441-497 (1955).

46b. R. C. Westphail, USAEC Report AECD-3864, 1-4 (1954).

47. Joint Committee on Powder Diffraction Standards, ASTM File No. 24748A (1974). Value is taken from Sturken and Post, Acta Crystallogr. 13, 852 (1960).

48. E. D. Devyatkova, B. Yä. Maizhes, and I. A. Smirnov, Fiz. Tverdogo Tela 1(4), 613-627 (1959).

49. R. Benz, J. Nucl. Mater. 29, 43 (1969).

50. W. A. Lambertson, M. H. Mue11er, and F. H. Gunze1, J. Amer. Chem. Soc. 74, 3406 (1952).

51. R. J. Ackermann and E. G. Rauh, High Temp. Sci. 5, 463 (1973).

52. M. Hoch and H. L. Johnston, J. Phys. Chem. 65, 1184 (1961).

53. R. J. Ackermann, E. G. Rauh, R. J. Thorn, and M. C. Cannon, J. Phys. Chem. 67, 762-69 (1963).

54. E. Shapiro, J, Amer. Chem. Soc. 74, 5233-35 (1952).

55. M. Hoch and H. L. Johnston, J. Amer. Chem. Soc. 76, 4833-35 (1954).

56. H. Y. Fan, J. App1. Phys. 20, 682-690 (1949).

57. D. W. Osborne and E. F. Westrum, J. Chem. Phys. 21, 1884 (1953).

58. T. G. Godfrey, J. A. Wooley, and J. M. Leitnaker, Oak Ridge National Laboratory Report ORNL-TM-1596 (1966).

58a. A. C. Victor and T. B. Douglas, J. Res. Nat. Bur. Stand., A 65, 105 (1961).

58b. J. C. Southard, J. Amer. Chem. Soc. 63, 3142 (1941). 
59. J. H. Koenig, Rutgers Univ. N. J. Ceram. Research Sta. Progr. Report 2, 1-117 (1953).

60. A. E. Wechsler and P. E. Glaser, Armed Services Technical Report ASD-TDR-63-574, 1-171 (1963).

61. B. J. Skinner, Amer. Mineral 42, 39 (1957).

62. B. Ohnysty and F. K. Rose, J. Amer. Ceram. Soc. 47, 398-400 (1964).

62a. M. Hoch and A. C. Momin, High Temperatures-High Pressures 1, 401 (1969).

63. W. A. Lambertson, M. H. Mueller, and F. H. Gunzel, Jr., J. Amer. Ceram. Soc. 36, 397-99 (1953).

64. J. A. Christensen, $\mathrm{UO}_{2}-\mathrm{ThO}_{2}$ Phase Studies, Quarterly Progress Report Research and Development Programs Executed for the Division of Reactor Development, October, November, December 1962, Hanford Works Report HW76559, pp. 11.5-11.6 (May 1963).

65. J. R. Springer, E. A. Eldridge, M. U. Goodyear, T. R. Wright, and J. F. Lagedrost, Fabrication, Characterization, and Thermal-Property Measurements of $\mathrm{ThO}_{2}-\mathrm{UO}_{2}$ Fuel Materials, Battle Memorial Institute Report BMI-X-10210 (Oct 1, 1967).

66. I. Cohen and R. M. Berman, J. Nuc1. Mater. 18, 77-107 (1966).

67. R. E. Latta and R. E. Fryxe11, J. Nuc1. Mater. 35, 195-210 (1970).

68. W. L. Lyon and W. E. Baily, J. Nucl. Mater. 22, 332-339 (1967)..

69. G. T'. Reedy and M. G. Chasanov, J. Nucl. Mater. 42, 341 (1972).

70. J. F. Kerrisk and D. G. Clifton, Nuc1. Technol. 16, 531-535 (1972).

71. A. E. Ogard and J. A. Leary, Thermodynamies of Nuclear Materials, Proc. IAEA Symp., Sept 4-8, 1967, IAEA, Vienna, p. 651 (1968).

72. R. A. Hein, L. A. Sjodahl, and R. Szwarc, J. Nucl. Mater. 29, 99 (1968).

73. L. L. Leibowitz, L. W. Mishler, and M. G. Chasanov, J. Nucl. Mater. 25, 356 (1969).

74. D. R. Fredrickson and M. G. Chasanov, J. Chem. Thermodyn. 2, 623 (1970).

75. T. D. Chikalla, Handford Works Report HW-69832 (1961).

76. R. A. Hein and P. N. Flagells, General Electric Co. Nuclear Systems Programs Report GEMP-578 (1968).

77. M. Tetenbaum and P. D. Hunt, J. Nucl. Mater. 34, 86-91 (1970).

78. L. Leibowitz, M. G. Chasanov, L. M. Mishler, and D. Fischer, J. Nucl. Mater. 39, 115 (1971). 
79. C. Holley, Ed., Thermodynamics and Transport Properties of Uranium Dioxide and Related Phases, Tech. Report Series No. 39, IAEA, Vienna (1963).

80. R. Penninckx and P. Nagels, private communication as cited in Ref. 79 .

81. D. Bethaux, P. Thomas, and L. Weill, C. R. Acad. Sci., Paris 253, 2043 (1961).

82. P. C. Held and D. R. Wilder, J. Amer. Ceram. Soc. 52, 182-186 (1969).

83. F. Cabannes, J. P. Stora, and J. Tsakiris, C. R. Acad. Sci., Paris Ser. B 261, 45-48 (1967).

84. T. T. Clauson, Handford Works Report HW-55414 (Nov 1958), and Uranium Dioxide: Properties and Nuclear Applications, J. Belle, Ed. pp. 196-197 (1961).

85. H. E. Swanson and R. K. Fuyat, Standard X-ray Diffraction Powder Patterns, NBS Circular 539, Vo1. II (1953).

86. J. A. Christensen, J. Amer. Ceram. Soc. 40, 607 (1963).

87. J. B. Conway, R. M. Fincel, and R. A. Hein, Trans. Amer. Nuc1. Soc. 6, 153 (1963).

88. R. E. Woodley, J. Nuc1. Mater. 50, 103-106 (1974).

89. H. C. Tsai and D. R. Olander, J. Nucl. Mater. 44, 83 (1972).

90. M: G. Chasanov, L. Leibowitz, and S: D. Gabelnick, J. Nucl. Mater. 49, 129-135 (1973/74).

91. E. A. Aitken and S. K. Evans, General Electric Co. Atomic Products Report GEAP-5672 (Oct 1968).

92. R. W. Ohoc, P. C. Bcrric, H. G. Bogenberger, and E. A. Fischer, Thermodynamics of Nuclear Materials 1974, IAEA, Vienna, p. 307, (1975).

93. Breitung, CaZculations of Vapor Pressure of Oxide Fuels up to $5000 \mathrm{~K}$ for Equilibrium and Nonequilibrium Evaporation, Kernforschungszentrum Karlscruhe Report KFK 2091 (1975).

94. J. E. Battles, W. A. Shinn, P. E. Blackburn, and R. K. Edwards, Plutonizm ]970, Nuclear Metallurgy, AIMMPE, New York p. 733 (1971).

95. R. W. Ohse and W. M. Olsen, ibid, p. 743.

96. R. L. Gibby, L. Leibowitz, J. F. Kerrisk, and D. G. Clifton, J. Nuc1. Mater. 50, 155-161 (1974).

97. A. E. Ogard and J. A. Leary, Thermodynamics of Nuclear Materials, IAEA, Vienna, 651 (1968). 
98. L. Leibowitz, D. F. Fischer, and M. G. Chasanov; J. Nucl. Mater. 42, 113 (1972).

99. R. L. Gibby, Hanford Engineering and Development Laboratory Report HEDL-TME-73-19 (Jan 1973).

100. L. Leibowitz, D. F. Fischer, and M. G. Chasanov, Argonne National Laboratory Report ANL-8082 (Feb 1974).

101. C. Affortit and J. Marcon, Rev. Hautes Temp. Refract. 7, 236 (1970).

102. B. J. Seddon, TRG Report 840 (R) (1956).

103. B. J. Seddon, TRG Report 1601(R) (1968),

104. J. G. Schnizlein and M. J. Steindler, in Chemical Engineering Division Fuel Cycle Technology Quarterly Report, April, May, June 1970, Argonne National Laboratory ReporL ANL-7735, 71-80 (July 1.970).

105. N. H. Brett and L. E. Russel, The Thermal Expansion of $\mathrm{PuO}_{2}$ and Some Other Actinide Oxides Between Room Temperature and $1000^{\circ} \mathrm{C}$, Proc. 2nd Int. Cont. on Plutonium Metallurgy, Grenoble, France, pp. 397-410 (Apr 1960).

106. M. Tokar, A. W. Niett, and T. K. Keenan, Nucl. Technol. 17, 147-152 (Feb 1963).

107. R. L. Gibby, Thermal Expansion of Mixed Oxide Fuel, Hanford Engineering and Vevelopment Laboratory Quarterly Technical Progress Report, HEDL-TME-74-3, (Sept 1974).

108. Sodium-Cooled Fast Reactor Development Programs, General Electric Co. Atomic Products, 28th Quarterly Report., Allgust-nrtnher; REAP 5700 (1968).

109. T. Takemura, S. Kasima, H. Matsui, and M. Koizumi, Thermal Expansion of (Pu-U) $)_{2-x}$, Annual Report of Tokai. Works, PNCT-AR-68 (Nov 1968).

110. J. M. LeBlanc and H. Andriessen, Research on Thermal Expansion of $\mathrm{UO}_{2}$, $\mathrm{PuO}_{2}$, and (U, PU) $\mathrm{O}_{2}$, Luropean Atomic Energy Cuiniliuily Repull EURAEC 434 (June 1962).

111. R. Benz and P. L. Stone, High Temp. Sci. 1, 4 (1.969).

112. J. Henney and J. W. S. Jones, UKAEA Report AERE-R 4993 (1965).

113. H. A. Wilhelm and P. Chiotti, Trans. Amer. Soc. Met. 42, 1295 (1950).

114. H. L. Schick, Thermodynamics of Certain Refractor Compounds, Vo1. 2, New York (1966).

115. J. Danan, CEA Report CEA-R-4453 (1973).

116. J. B. Narness, J. C. Mathews, and N. Morton, Br.. J. App1. Phys. 15, 963 (1964). 
117. The Joint Committee on Powder Diffraction Patterns, ASTM File No. 15-36 (1974). The value is from the work of Kempter and Krikorian, J. Less-Common Metals 4, 244 (1962).

118. R. S. Street and T. N. Waters, 'the I'hermal Expansion of the ThC and ThN, UKAEA Report AERE-M-1115 (Oct 1962).

119. P. Chiotti and R. W. White, J. Nucl. Mater. 23, 37-44 (1967).

120. T. Satow, J. Nucl. Mater. 21, 343-344 (1967).

121. S. Aronson, E. Cisney, and K. A. Gingerich, J. Amer. Ceram. Soc. 50, 248-52 (1967).

122. S. Peterson, R. E. Adams, and D. A. Douglas, Jr., Properties of Thoxizm, Its Alloys and Its Compounds, Utilization of Thorium in Power Reactors, IAEA (1966).

123. N. M. Griesenauer, M. S. Farkas, and F. A. Rough, Thorium and Thorium Compounds as Potential Thermal Breeder Fuels, USAEC Report BMI-1680 (Ju1y 28, 1964).

124. C. E. Johnson, Ed., Thermophysical and Mechanical Properties of Advanced Carbide and Nitride Fuels, Argonne National Laboratory Report ANL-AFP-27 (.Tune 1976).

125. A. Sheth and L. Leibowitz, Equation of State and Transport Properties of Uranium and Plutonium Carbides in the Liquid Region, Argonne National Laboratory Report ANL-AFP-11 (Sept. 1975).

126. M. Tetenbaum. A. Sheth, and W. Olson, A Review of the Thermodynamics of the U-C, Pu-C, and U-Pu-C Systmes, Argonne National Laboratory Report ANL-AFP-8. (June 1975).

127. E. K. Storms and R. J. Ackermann, Thermodynamic Properties of the Uranium-Carbon System, IAEA Panel on the Assessment of the Thermodynamic Properties of the U-C, Pu-C, and U-Pu-C Systems, Grenoble, France, May 6-8, (1974).

128. M. J. Wheeler, E. King, C. Manford, and H. J. Hedger, J. Brit. Nucl. Energy Soc. 10, 55 (1971).

129. H. D. Lewis and J. F. Kerrisk, Electrical and Thermal Transport Properties of Uranium and Plutonium l'arbides, Los Alamos Scientitic Laboratory Report LA-6096 (Mar 1976).

130. L. N. Grossman, J. Amer. Ceram. Soc. 46, 264 (1963).

131. R. DeConinck, Physical Properties of Uranium Carbides, Annual Scientific Report, 1973, BLG 495/74, ed. R. Billiau, K. Bobin, G. Michiels, and J. Proost.

131a. R. Mendez-Peñalosa and R. E. Taylor, J. Amer. Ceram. Soc. 47, 101 (1964). 
132. J. F. Andrew and T. W. Latimer, Review of Thermal Expansion and Density of Uranium and Plutonium Carbides, Los Alamos Scientific Laboratory Report LA-6037-MS (Nov 1975).

133. C. P. Kempter, J. Less-Common Metals 10, 294 (1966).

134. D. C. Fee and C. E. Johnson, Phase Equilibria and Melting Point Data for Advanced Fuel Systems, Argonne National Laboratory Report ANL-AFP-10 (June 1975).

135. J. G. Reavis, K. A. Johnson, and J. A. Leary, Plutonium 1970, Nuclear Metallurgy, AIMMPE, New York, p. 791 (1971).

136. L. Leibowitz et al., Chemical Engineering Division Reactor Safety and

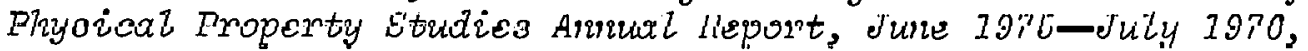
Argonne National Laboratory Report ANL-76-100.

137. H. K. Lonsdale, and J. N. Graves, Voporization of the Dicarbilles of Uranium, Thorium, and Protactinizm, Thermodynamics of Nuclear Materials, IAEA Viennd, pp. 601-623 (1962).

138. D. D. Jackson et al., J. Phys. Chem. 68, 1516-1523 (1964).

139. E. K. Storms, The Refractory Carbides, Chapter X, The Thorium-Thorium Dicarbide System, Academic Press, New York (1967).

140. R. A. Kent, Ph. D. Thesis, Michigan State University, East Lansing, Mich., cited by Storms in Ref. 139.

141. E. F. Westrum, Jr., Y. Takahashi, and N. D. Stawt, J. Phys. Chem. 69, $1.520-1.524(1.965)$.

142. Y. Takahashi, E. F. Westrum, Jr., and R. A. Kent, J. Chem, Eng. Data 10, 128-129 (1965).

143. C. E. Holley, Jr., and E. K. Storms, Thermodynamics of Nuclear MateriaZs, Proc. IAEA Symp., 1967, IAEA, Vienna, p. 397 (1968).

144. Joint Committee on Powder Diffraction Patterns, ASTM File No. 14-203 (1974). Value is from Hunt and Rundle, J. Amer. Chem. Soc. 73, 4777 (1951).

145. S. Langer et al., Studies in the Thorium-Carbon Binary System, Proceedings of the International Symposium on Compounds of Interest in Nuclear Reactor Technology, J. T. Waber, P. Chiotti, and W. N. Miner, Eds., AIME Spec. Report No. 13, Metallurgical Society, New York, pp. 359-386 (1.964).

146. J. L. Cook, Studies of the Thorium-Uranium Dicarbide Pseudobinary System in the Presence of Excess Grophite, Oak Ridge National Laboratory Report ORNL-TM-1188 (Sept 1965).

147. J. T. Dolton, P. E. Potter, and T. L. Shaw, Plutonizm 1965, Chapman and Hall, London, p. 775 (1967). 
148. N. A. Hill and O. B. Cavin, USAEC Report ORNL-3588 (1964); J. Amer. Ceram. Soc. 47, 360 (1964).

149. N. H. Krikorian and T. Wallace as quoted by E. K. Storms in The Refractory Carbides, Academic Press, New York (1967).

150. Joint Committee on Powder Diffraction Patterns, ASTM (1974). 